เ В 809 192 


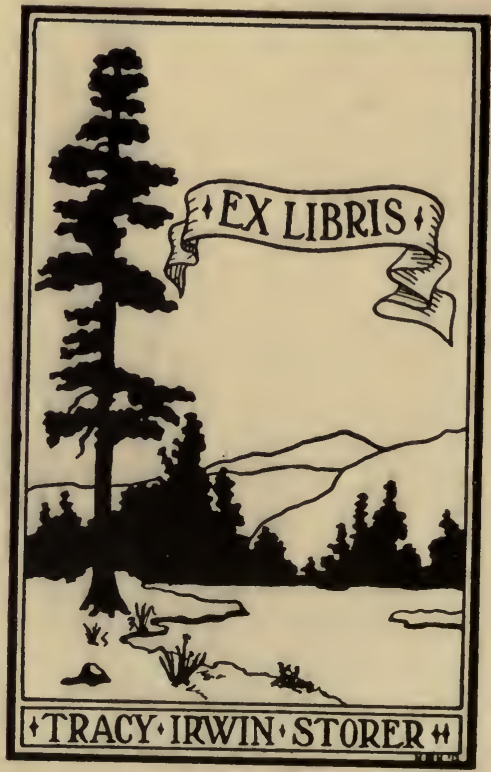

Donated to

LIBRARY

UNIVERSITY OF CALIFORNIA

DAVIS 
Digitized by the Internet Archive in 2007 with funding from Microsoft Corporation 
The squamation is fine and powdery. Compared with Lyromorvelua, to which it is nearest allied, besides the very different style of coloration, the primaries are narrower, costa straighter; secondan ies more triangular, owing to the rectangular inner angle. Bat in the structure of the head, of the antennx, of the thorax and abdomen it agrees closely with Lycomorpha, and these eharagters are those which place it without doubt in the Zygænidæ, though after a casual ' glance one would not hesitate to call it a Lithosian. The bluish scales of the body, the dark mahogany colored tegument, the fine powdery squamation, and the slender very equally jointed legs and pectinated antennæ aid in determining the true systematic position of this interesting genus.

Froin the resemblance to the parallel genera Hypoprepia and Atolmis, among the Lithosiidæ, I have proposed the name above given.

A. Grotei nov. sp. Vermillion red and smoky purple; head and appendages purple, thorax red; primaries red throughout except the purple fringe and the edge of the outer third of the costa. Secondaries red on the basal third, beyond smoky purple ; the red extends from just within the middle of the inner edge to near the apex upon the costal edge. Legs purple, concolorous with the abdomen. Beneath colored the same as above. There are no other markings on the wings.

Length, .38; exp. wings, 1.20 inch.

Pike's Peak, Colorado 'Terr. (Coll. Phil. Ent. Soc.)

Dedicated to Mr. A. R. Grote, to whose kindness in securing for study this and many other rarities I am under special obligations.

\section{EXPLANATION OF THE PLATES.}

Plate I. Fig. 1. Ctenucha virginica Grote. 1a, Palpus enlarged. 1b, Head denuded and enlarged. 1c, Primary wing. 1d, Secondary wing.

Fig. 2. Larva seen from above. $2 a$, side view. $2 c$, front view of head enlarged. 2d, last abdominal ring seen from above.

Fig. 3. Young larva, after the fourth moult.

Fig. 4. Pupa seen from above. $4 a$, side view.

Plate II. Fig. 1. Alypia octomaculata Hubner, head denuded and enlarged. $1 a$, Primary wing. 1b, Secondary wing.

Fig. 2. Pupa of Eudryas grata Boisduval. $2 \alpha$, dorsal view.

Fig. 3. Head of the same, denuded and enlarged. $3 a$, Primary wing. $3 b$, Secondary wing.

Fig. 4. Lycomorpha Pholus Harris, head denuded and enlarged. $4 a_{y_{*}}$ Primary wing. $4 b$, Secondary wing. 


\section{Prve. Ersup Int., IV. Pf. 48-80, Sept.1864; H..81-18,}

IV. Catalogue of the Birds found at Springfield, Mass., with Noles on their Migrations, Habits, $\mathcal{S}^{\circ}$. ; together with a Lisl of those Birds found in the Slate not yet observed at Springfield. BY J. A. AluEN.

(Communicated May' 2, 1864. )

Nearly all the land birds known to inhabit New England are found in the Valley of the Connecticut, at one season or another ; and during spring and fall the number of passengers from the northern to the southern parts of the country, and vice versa, is immense; even some of those species usually esteemed quite rare occur in considerable numbers. The number of individuals of land birds, during the periods of migration, seems to be much greater at Springfield than at most localities in the eastern part of the State; yet some species are more numerous in Eastern Massachusetts than at Springfield; and some are common there through the breeding season, which at Springfield are almost unknown, or at least occur in much fewer numbers. Among such may be mentioned Caccy $¥ u s$ americamus, Hirundo bicolor, C'arpodacus purpureus, the Ammodromi, \&c. The rapacious birds, owing to the absence of extensive woods, are comparatively rare, especially in summer and winter, and the water birds are limited to the fresh water or river Ducks and Grallæ, which are, with few exceptions, far from numerous.

Among some of those species noticed as of very rare occurence here, may be mentioned Nyctale Richardsonii, Picoides arcticus, Centurus carolinus, Helminthophaga peregriva, H. celata, Dendroica tigrina, Icleria viridis, Mimus polyglottus (found breeding), Melospiza Lincolnii, Coturniculus Henslowii, Corvus curnivorus, \&c. The "Turdus alicie" of Baird, I have found to be not rare; and from a careful examination of many specimens of both 'T. alicia and T. Swainsonii, have found alicice to be based on faintly colored specimens of Swainsonii, and not to be a distinct-species, as heretofore 
supposed. 'This subject is noticed at length under Turdus Swansonii.

Springfield being situated near the northern confines of the Alleghanian Fauna, some of the more southern species found here are represented merely by a few individuals in the breering season, while the southern limit of many others properly belonging to the Canadian Fauna is removed but a few miles to the north, varying from sixty to one hundred miles in the Valley of the Connecticut, and in the mountainous districts of Western Massachusetts falls nearly as low as Springfield.

I have designed to include no species, in the following list, which I have not known taken or observed in the immediate vicinity of Springfield, (except in the case of a few Ducks, noticed below,) preferring to err in omitting some really existing in the prescribed region than to include a single species not belonging to the locality. I have introduced, however, those very probably occurring, which have not, to my knowledge, been observed here ; but these are not reckoned as a part of the list. The times of migration given are generally an average of observations covering several years.

In order to render the list as complete and valuable as possible, I have not failed to solicit aid from others, and am pleased to be able to acknowledge valuable assistance; chiefly from 'Messrs. C. W. Bennett and L. Hyde, whose very complete collection of our native birds forms a valuable part of the collections of local natural history in the "Ethnological and Natural History Museum" established a few years since in Springfield; to $\mathrm{Mr}$. B. Hosford, for various useful notes, and to Dr. Wm. Wood, of East Windsor Hill, Ct., who has kindly furnished me with many valuable facts, particularly in reference to the water birds. The names of contributors follow the facts resting on their authority. Several of the Ducks included in the list, (Aythya vallisneria, Bucephala albeola, Harelda glacialis, Melanetla velvetina,) are inserted from their having been taken on the Connecticut River, by Dr. Wood, some fifteen miles below Springfield; and though not known to have been taken here, undoubtedly occur, and have only been overlooked from a want of more thorough searching on the part of collectors. The whole number of species included in the Springfield list is one hundred and ninety-five; the number of those found in Massachusetts not observed at Springfield is ninety-two; of which the greater part are truly coast species.

ESSEX INSTITUTE PROCEED. VOL. IV. G. 
In order to give a complete list of the birds of our State, I have appended a catalogue of those found in Massacliusetts not yet noticed at Springfield. No species is included of which there is not good evidence that it has been taken in the State. Some occasional visitors may have been overlooked, but it is believed such instances are few. Those probably occurring but not to my knowledge detected, are also mentioned but are not counted as a part of the list. To present a general view of the Ornithology of our State in a condensed form, I have appended tabular lists of those birds that are resident the

- whole year in the State, those that breed, those that are summer, winter, or spring and autumn visitors, and those that are merely rare, occasional, or chance visitors, \&c.

1. Falco anatum Bonap. Duck Hawk. Very rare. One or two pairs are known to breed regularly on Mount Tom, some fifteen or twenty miles north of Springfield. Nest on the rocks, very early in the season, the young being full grown by the last of June. Mr. C. W. Bennett, who gives me these facts, took some young birds from the nest a few years since. This species has also been found breeding on 'Talcott Mountain, Ct., a few miles south-west of Hartford. Four nearly full-fledged young were taken from the nest June 1st, 1861, and the female was shot.* (Dr. W. Wood, in Hartford, Ct., Times, June $24 \mathrm{th}, 1861$. See a valuable series of twenty-one articles, by Dr. Wood, on the Rapacious "Birds of Connecticut," published in the Hartford Times, March 14th to August 9th, 1861.)

2. Hypotriorchis columbarius Gray. Pigeon Hawk. Very rare. Seen in spring and fall. May 7th, 1861, obtained a male in perfectly adult plumage.

3. Tinnunculus sparverius Vieill. Sparrow Hawk. Not common. Seen in spring and fall. Has been found breeding at Williamstown, Mass. (Brewer's N. Am. Oöl. pt. I. p. 17.)

4. Astur atricapillus Bonap. Goshawk. "Partridge Hawk." Winter visitant. Usually rare, but was quite common in the winter of 1859-60. Arrives about the first week in November.

* Since the above was written, the eggs have been obtained (April 19th, 1864,) from a nest on Mount Tom, by Mr. C. W. Bennett, of Springfield. The female was also obtained, and the identity of the eggs ascertained beyond question. 
5. Accipiter Cooperii Bonap. Cooper's Hawk. "Chicken Le h.98 Hawk." Common summer visitant, breeding, but is most numerous in September.

6. Accipiter fuscus Bonap. Sharp-shinned Hawk. "Pigeon Hawk." Summer visitant, breeding; common, particularly in spring and fall.

7. Buteo borealis Vieill. Red-tailed Hawk. "Hen Hawk." Probably resident, but most numerous ' in fall and spring; and breeds here.

8. Buteo lineatus Jard. Red shouldered Hawk. Not uncommon, arriving early in spring, and breeds here. Is most common in autumn, when those that breed further north are migrating southward.

9. Buteo pennsylvanicus Bonap. Broad-winged Hawk. Quite rare; breeds.

10. Archibuteo lagopus Gray. Rough-legged Hawk. Winter visitant. Not common, except occasionally, and in particular localities.

11. Archibuteo sancti-johannis Gray. Black Hawk. Rare winter visitant.

12. Circus hudsonius Vieill. Marsh Hawk. "Blue Hawk." "Bog-trotter" of sportsmen. Common summer visitant; arrives early in March, and nests on the ground in the marshes, often many years on the same site. It is by far our most common Hawk. Both sexes incubate.

13. Halicetus lencocephalus Savigny. White-headed Eagle. "Bald Eagle." Not common; sometimes breeds on Mt. Tom, about twenty miles north of Springfield

14. Pandion carolinensis Bonap. Fish Hawk. A few are seen along the Connecticut and its tributaries during the spring months. Have never heard of its breeding in this vicinity.

15. Bubo virginianus Bonap. Great Horned Owl. "CatOwl." Rather common. Resident, but seems to be more common in autumn and winter.

16. Scops asio Bonap. Mottled or Red Owl. "Screech Owl." Resident, and probably our most common species of Owl.

17. Otus americanus Bonap.*. Long-eared Owl. Not

* Strix americana Gmelin, Syst. Nat. I, (17/8) 288; Otus Wilsonianus Less. Traité d'Orn., I, (1832) 130.-Why the specific name americanus adopted for this species by the later ornithologists I cannot $\mathrm{ng}$ that having the priority of all others. 
common. Probably resident, but most frequently taken in autumn.

18. Brachyotus Cassinii Brewer. Short-eared Owl. Resident. Rather common in autumn and winter. Dr. Wood has found it breeding in Connecticut, a few miles from Springfield.

19. Syrnium nebulosum Gray. Barred Owl. Quite common. Resident.

The Great Gray Owl (S. cinereum Aud.) may occur occasionally, but I have never known it taken here.

20. Nyctale acadica Bonap. Acadian Owl. "Little Owl." Pretty rare. Resident.

21. Nyctale Richardsonii Bonap. Richardson's Owl. Very rare winter visitant. Obtained a specimen in December, 1859. A specimen in the Museum of Comparative Zoölogy, Cambridge, taken at Malden, Mass., and one taken by Dr. W. Wood, in East Windsor, Ct., were obtained the same winter.

22. Nyctea nivea Gray. Snowy Owl. Winter visitant, and usually rare; in some winters quite common. Has been taken third week in November.

23. Coccygus americanus Bonap. Yellow-billed Cuckoo. Extremely rare; in the eastern part of the State it occurs frequently. Though it has been an object of special search with collectors here for several years, but one specimen has been obtained. Dr. Wood says it is "very rare" at EastWindsor Hill, Ct., where he has found its nest and eggs.

24. Coccygus erythrophthalmus Bonap. Black-billed Cuckoo. Rather common summer visitant, arriving about May 10 th.

25. Picus villosus Linn. Hairy Woodpecker. Resident, but quite rare in summer; more common in winter.

25, Picus pubescens Linn. Downy Woodpecker. Resident, and common at all seasons.

- 27. Picoides arcticus Gray. Black-backed Threc-toed Woodpecker. A very rare or accidental winter visitant. The only specimen I have known taken here I shot in January, 1860 ; a Woodpecker, however, was seen here for several weeks in March of the same year, which I think, from descriptions of it, must have been this species. 
28 Sphyropicus varius Baird. Yellow-bellied Woodpecker. Not common, and only seen in fall and spring when migrating. I have never seen this species in summer, and do not think it breeds here, though they breed plentifully on the hills in Western Massachusetts, twenty or thirty miles west of Springfield. (W. H. Niles.)

29. Centurus carolinus Bonap. Red-bellied Woodpecker. Summer visitant. Accidental. Saw one May 13th, 1863. It has been taken several times in Connecticut, but occurs in New England only as a straggler. Found in the breeding season in Western Massachusetts by Prof. Emmons. (Peabody's Rep. on the Birds of Mass.)

30. Melanerpes erythrocephalus Swain. Red-headed Woodpecker. Very rare summer visitant. Have taken but two specimens in five or six years. Three were taken in 1860 by Messrs. Bennett and Hyde. A few are still known to breed within about twenty miles, in several directions, (at Amherst, Mass., C. W. Bennett.) Twenty-five or thirty years ago they were very abundant here.

31. Colaptes auratius Swain. Golden-winged Woodpecker. "Yellow Hammer." "Wakeup." Summer visitant, breeding very abundantly. Arrives about the first of April or last week. in March ; leaves about October 12th.

32. Trochilus colubris Linn. Humming Bird. Common - summer visitant, breeding plentifully. Arrịves early in May, and in August is very abundant wherever the Impatiens fulva abounds.

33. Chcetura pelasgia Steph. Chimney Swift. "Chimney Swallow." Abundant. Usually arrives about the first of May, but are frequently seen the last week in April; greater part leave early in September, but some often remain till the middle of September, and even sometimes till near the first of October. Arrives earlier and commonly remains later than any of the true Swallows, except perhaps Hirundo bicolor. Raises two broods, the last young sometimes not leaving the nest before August 15th or 20th.

34. Antrostomus vociferus Bonap. Whip-poor-Will. Common summer visitant, arriving about April 25th. $\mathrm{A}$ few of the males are musical till into September; have heard them throughout the summer till September 25th, about which time they leave us. 
35. Chordeiles popetue Baird. Night Hawk. Common summer visitant. Arrives early in May, and departs south early in September. Many leave in large straggling parties during the latter part of August.

36. Ceryle alcyon Boie. Belted Kingfisher. Common. Chiefly a summer visitant, arriving in March, but a few usually remain about open streams during winter.

37. Tyrannus carolinensis Baird. King Bird. Summer visitant, breeding very abundantly. Arrives about May 10th, and departs early in September; usually by the 10th or 12 th, sometimes by the 1 st.

38. Myiarchus crinitus Cab. Great-crested Flycatcher. Rare summer visitant. Have taken it May 15th, and Sept. 17th. Breeds on Mt. Tom (C. W. Bennett), and in some other parts of the State.

39. Sayornis fuscus Baird. Pewee. Phœbe. Common summer visitant, arriving about the last of March. Begins nesting in April, and have found freshly laid eggs the middle of August, it raising two, perhaps occasionally three, broods, in a season.

40. Conlopus borealis Baird. Olive-sided Flycatcher. Summer visitant; not very rare. Arrives about May 12th, and breeds in high, open woods, far away from which it is seldom seen. Leaves about the middle of September.

41. Contopus virens Cab. Wood Pewee. Very common summer visitant, breeding in the open woods quite abundantly, and occasionally in orchards. Arrives about May 15th, and leaves September 10 th to 15 th.

42. Empidonax Traillii Baird. Traill's Flycatcher. Rather rare summer visitant; arrives May 10th to 15th, and probably breeds.

43. Eimpidonax minimus Baird. Least-Flycatcher. Abundant summer visitant. Arrives the last of April ; sometimes as early as April 20th. Most abundant in orchards and cultivated grounds, where it commonly breeds, but also frequents open woods. Leaves before, or by, the middle of September. Exceeds in abundance all the other Empidonaces taken together.

44. Empidonax acadicus Baird. Acadian Flycatcher. Rather rare summer visitant. Breeds in swamps and low 
moist thickets, which are its exclusive haunts. Under Muscicapa querula (Small Green-crested Flycatcher), Wilson, in a few words, has very correctly indicated the habits and notes of this species. It is the most spirited and tyrannical of all our Empidonaces, with which its sharp, quick note, like quequeah, uttered sharply and hurriedly, and its erect, Hawk-like attitude eminently accord. It is very quarrelsome with its own species, a battle ensuing whenever two males meet; they pursue each other fiercely, with snapping bills and sharp querulous twittering notes. It is also a very shy and difficult bird to collect, frequenting exclusively, so far as I have obscrved, thick alder swamps and swampy thickets, keeping either concealed among the thick bushes, or. at too great a distance from the collecter.

45. Empidonax flaviventris Baird. Yellow-bellied Flycatcher. Rare. Have taken it from May 15th to June 5th.

46. Turdus. mustelinus Gmelin. Wood 'Thrush. Summer visitant, arriving May 1st to 10th. Not common, usually breeding in deep, moist woods. Is more terrestrial in its habits than the other Wood Thrushes.

This species has commonly been described by authors as remarkable for its shyness of man, and for selecting for its haunts the most secluded woodlands; and though this is generally true, there are some noteworthy exceptions. So far as I have seen, however, it is not so recluse in its habits as has been very generally supposed; having found it (in -May)-where there were but few trees and a scanty undergrowth, and even within the limits of a thickly peopled village. Mr. W. H. Hall has informed me of a nest of this spccies, which he found in the summer of 1861, built within a few yards of the road leading up Mt. Holyoke. For three successive summers a single Wood Thrush has lived among the elms and maples of Court Square, Springfield, spending the whole season in its immediate vicinity, pouring out his melodious strains at early dawn, and at various hours of the day till late in the evening, as wholly undisturbed by the people on the walks beneath him, or by the noise and rattle of moving vehicles in the contiguous streets, as though in the usual wild-wood haunts of his species. His superior musical powers have caused him to become a well-known and protected favorite with the people, familiarly searching for his food along the gravel wallss of the Square. 
47. Turdus Pallą̧ii Cabanis. Hermit Thrush. Abundant in spring and autumn. Seen in small parties from April 15th to May 10th in spring, and in fall from October 1st till November, sometimes till the 10th, commonly in swamps and low woods, and occasionally in open, plowed fields. Never sings while here, and is quite unsuspicious. Have not found it breeding here.

48. Turdus fuscescens Stephens. Tawny Thrush. Wilson's Thrush, Veery. Abundant summer visitant. Breeds in swamps and low woods, nesting on or very near the ground, beginning to sit the first week in June; have found its eggs May 29th. Arrives about May 10th, and leaves early in September. During the summer months is quite arboreal in its habits, collecting a large part of its insect food among the foliage of the trees. It is the most numerous here of all the woodland Thrushes, and the only one that breeds here in abundance, and the only one, excepting T. mustelinus. Have found three nests in an hour's walk.

49. Turdus Swainsonii Cab. ('T'urdus Swainsonii and 'T. alicia of Baird.) Swainson's Thrush. Olive-backed Thrush. Common in spring and fall. Seen in spring from May 15 th to June $3 d$, usually in small parties about woodlands, but often frequents open fields, and even gardens; is quite unsuspicious, and seldom sings while here.

After a critical examination of a very extensive series of specimens, including many fresh, I am forced to the conclusion that T. alicice and T: Swainsonii form but one species. I have carefully studied the bills, feet, wings, size, and proportions for specific differences, and find that, though there is more or less variation in all these, as there is among individuals of almost every species, there is nothing that approaches to constant specific difference. Indeed, the principal character that has ever been urged as separating them is that of the color. But this I find is not a constant character. I have had specimens before me during the last year exhibiting every gradation in the color of the breast, sides of the neck, eye circle, \&c., from the strongly buff-tinted of the true $T$. Swainsonii to the pale gray of the typical "alicia," where the buff was scarcely perceptible or quite obsolete.

Prof. Baird, in his original description of alicice (P.R.R. E.xp. and Surv. IX. 217) observes: "These parts [sides of the neck and breast] are not of as pure white as the belly, 
having the faintest possible shade of yellowish red, but it is barely appreciable, nor is it any more distinct in raising the feathers. There is the faintest possible shade of reddish in the tail and its coverts above, but this is only to be observed on a close examination. This species comes much nearest to Turdus Swainsonii, the Olivebacked.Thrush, agreeing with it in the dark greenish olive of the upper surface. This, however, is decidedly darker, and showing a clearer greenish than usual in the other. The absence of any buff on the throat, breast, and sides of the head, and the predominating ashy on the latter, with a white ring instead of a reddish yellow round the eye, are strong points of distinction. The bill appears more slender, and the whole bird is larger. It is barely possible that it may constitute a variety only of $T$. Swainsonii; but if so a very strongly marked one."

Detecting T. "alicice" among specimens I had collected, and many specimens intermediate in color between this form and strongly marked $T$. Swainsonii, I began to search for some more constant character than color to separate the two forms ; and found by extensive measurements that both the largest and the smallest specimens occurred in the form recognized as $T$. Swainsonii, though some $T$. alicice were larger than the average of the series. On comparing the proportions of the primaries, some alicice agreed with Swainsonii while others differed. Comparisons made between the bills, feet and other characters, gave similar results; while in color the majority of the specimens ranged between those having the greatest amount of reddish-yellow and those in which the buff was scarcely appreciable. The difference in color is merely one of intensity, dependent neither upon sex nor season, possibly upon age, and extends throughout the plumage; thus those that have the breast of the brightest buff, have also more of this tint pervading the whole plumage, the paler specimens being of the purest dark olive above, without the brownish cast observable in the more rufous individuals.

Among individuals of Turdus fuscescens, collected the past summer at Springfield, I have detected a difference similar in kind and as great in degree as that separating forms heretofore considered typical respec-

ESSEX INST. PROCEED. VOL. IV. H. 
tively of T. Swainsonii and T. alicice. Thus one specimen is very highly colored throughout, being very bright reddish brown above, and has the breast bright reddish buff, of about the same tint as in highly colored T. Swainsonii, and the spots very distinct, while the other is very pale throughout, being of a decided yellowish brown above, and has the breast pale buff, and the spots more indistinct than in the first. Both specimens were taken May 29th, 1863. The depth of color also varies more or less in different specimens of Turdus Pallasii, though hardly so marked as in T. Swainsonii; but evẹn in T. Swainsonii the gradations from one extreme to the other are so minute and complete that the state describer as $T$. alicice can now hardly be considered "a very strongly marked" variety.

50. Turdus (Planesticus) migratorius Linn. Robin. Abundant summer visitant. Are sometimes seen in February, but commonly arrive in March, from the 15th to the 25th. Are last seen in autumn from the 7 th to the 14th of November. Breeds plentifully in orchards and gardens, often in the woods, and is a fumiliar inhabitant in the village and city. Have observed it at all seasons in the eastern part of the State, where many are resident. Some also spend the winter along the south side of Mount Holyoke, feeding on the berries of the red cedar.

51. Sialia sialis Baird. Blue Bird. Abundant, often arriving in February, and is generally common by the 15 th to the 25th of March. Nests early, the first brood of young generally leaving the nest as soon as June 1st, and the second during the third week in July. Commonly leaves about the last week in October.

52. Regulus calendula Licht. Ruby-crowned Kinglet. Common spring and autumn visitant. Seen in spring from A pril 15th to May 12th; in autumn from October 1st to 20th. Have never seen it here in winter.

53.. Regulus satrapa Licht. . Golden-crested Kinglet. Abundant winter visitant. Arrives about October 1st, and departs north again about April 10th to 15 th.

54. Anthus ludovicianus Licht. Titlark. "Sky Lark". Spring and autumn visitant. Seen for a week or ten days in the early part of October, often in large flocks, fre- 
quenting stubble and newly-plowed fields, and the muddy banks of streams and ponds; also for a few days in May.

55. Mniotitta varia Vieill. Black and White Creeper. Common summer visitant. Have found it breeding, nesting on the ground. It appears to nest in various siturtions, according to different observers; in hollow trees, on the ground, and in crevices among rocks. Arrives alout April 25th, and for several weeks is very abundant, but the greater part going further north to breed, is not so common in summer, but becomes abundant again the last of August and early in September.

56. Parula americana Bonap. Blue Yellow-backed Warbler. Very common, particularly in May. Many remain through the summer and breed, nesting about June 1st. Seem to prefer high mixed woods and thick spruce and larch swamps, keeping almost wholly in the tops of the taller trees and near the extremities of their larger branches. On their first arrival, about May 5th, they firequent the orchards, and keep lower among the undergrow th in the woods than they do later in the season. Leaves 10 th to the 15th of September.

57. Geothlypis trichas Cab. Maryland Yellow-throated Warbler. Summer visitant. Very abundant, breeding plentifully in all swampy situations, nesting on the ground. Arrives about May 10th, and leaves the first or second week in September.

58. Geothlypis Philadelphia Baird. Mourning Warbler. Very rare. Have taken two specimens about the middle of September. Five specimens of this Warbler were taken in Lynn, a few years since, from the 4 th to the 29 th of September, by S. Jillson. (Ms. notes of S. J.)

The Connecticut Warbler (Oporornis agilis Baird) may probably be found here as an extremely rare species, but I have not known it detected here.

59. Icteria viridis Bonap. Yellow-breasted Chat. Ex- Su f.98 tremely rare. Has been seen here but a few times. In May, 1863, I saw a few pairs which appeared likely to breed here, but heing harrassed and some of them killed, by collectors, the others sought a safer haunt. Was seen here in September, a few years since, by R. B. Hildreth, Esq.

60. Helminthophaga ruficapilla Baird. Nashville War- 
bler. Abundant in May, and in the early part of autumn. Arrives May 1st to 5th, and for two or three weeks is a common inhabitant of the orchards and gardens, actively gleaning insects among the unfolding leaves and blossoms of the fruit trees. Nearly all go north, but a few retire to the woods and breed. During June, 1863, I frequently saw them in my excursions in the woods, often three or four males in an hour's walk. Its song so much resembles the song of the Chestnut-sided Warbler (Dendroica pennsylvanica) that it might readily be mistaken for it. To this cause, and to the difficulty of seeing such small birds in the dense summer foliage, is doubtless owing the firct of its being so commonly overlooked by naturalists during the summer months, rather than to its extreme rarity in this latitude at that season. I have found the nest of this species for two successive seasons, as follows:May 31st, 1862, containing four freshly laid eggs. The nest was placed on the ground, and sunken so that the top of the nest was level with the surface of the ground, and protected and completely concealed above by the dead grass and weeds of the previous year. It was composed of fine rootlets and dry grass, lined with fine dry grass and a few horse hairs, and covered exteriorly with a species of fine green moss. The eggs were white, sprinkled with light reddish brown specks, most thickly near the larger end. Longer diameter sixty, and the shorter fifty, onehundredths inches. The following year, June 5th, 1863, I found another nest of this species, within three or four feet of where the one was discovered the previous year, and containing three eggs of this species and one of the Cow Bunting, in all of which the embryos were far advanced. The nest in every particular was built and arranged like the one above described, and the eggs must have been laid at just about the same season. In both cases the female bird was secured, and the identity of the nests ascertained beyond question. The locality of the nests was a mossy bank, at the edge of young woods, sloping southward, and covered with bushes and coarse plants. Probably the male of the first nest, mating again, selected the same site for the second nest; and it may have been occupied for a longer time.

61. Helminthophaga celata Baird. Orange-crowned 
Warbler. Very rare; perhaps accidental. Shot a single specimen May 15th, 1863. Saw quite a number of this species among the fruit trees of the garden and orehard, then in blossom, but thinking them only pale individuals of $H$. ruficapilla, which thronged every tree, I neglected at first to shoot. Finally, being strongly in doubt, I shot one, and the specimen proved to be $H$. celata, which, as the group immediately passed on to a piece of woods, was the only one I secured.

62. Helminthophaga peregrina Cab. Tennessee Warbler. Very rare. Have taken it September 19th, and May 29th.

The Golden-winged Warbler ( $H$. chrysoptera Cab.) probably rarely occurs here, as it is occasionally taken in other parts of the State. Probably also the Blue-winged Yellow Warbler ( $H$. pinus Baird) and the Worm-eating Warbler (Helmitherus vermivorus Bonap.) may yet be detected here, but they must occur only as very rare visitants. Of the - Helminthophaga, $H$. ruficapilla is abundant and breeds here, while all the others appear to be extremely rare.

63. Siurus aurocapillus Swain. Golden-erowned Wagtail. "Oven Bird." Very abundant summer visitant, breeding plentifully, in every thicket and pateh of woodland. Arrives about May 10th, immediately making known its presence by its loud echoing song, heard every. where in the deep woods. Leaves first or second week in September.

64. Siurus noveboracensis Nutt. Water Wagtail. Not uncommon in spring and fall, and apparently a few breed here, having seen them in June, July, and August; is very rare during the summer months. Arrives May 12 th to 20 th.

The Large-billed Water Wagtail (Siurus ludoviciana Bonap.) ought to occur here, but after several seasons of careful search I have not found it.

65. Dendroica virens Baird. Black-throated Green Warbler. Abundant in May, and the last week of August and the first part of September. Though some breed, it is not much observed in summer, as it keeps mostly in the tops of the trees in thick woods. Arrives May 5 th and later, being most numerous in spring from May 15 th to 
25 th, when it is often seen in the gardens and orchards, gleaning insects among the opening foliage.

66. Dendroica canadensis Baird. Black-throated Blue Warbler. Common from May 15th to 25th, and again the fore part of September. Found in the breeding season on Mt. Holyoke (C. W. Bennett), and along the ridges in the western part of the State (B. Hosford).

67. Dendroica coronata Gray. Golden-crowned Warbler. Myrtle Bird..Yellow-rumped Warbler. Very abundant spring and autumn visitant. Commonly arrives first week in May, in great numbers, but generally passes rapidly northward, and is usually abundant but four or five days. Stragglers are sometimes seen the last of April, and a ferv as late as May 15th. Are often so abundant as to seem to be in an almost continuous loose flock, equally common in orchards, thickets, cultivated grounds and woodlands, keeping up a constant motion northward, others continually arriving to fill the places of those which have passed on. In autumn they are longer in passing, moving much more leisurely than in spring; are very abundant fir ten days to two weeks in the fore part of October. Often alights on the ground, particularly in autumn, and is then rather more common about cultivated fields, flying along fences and hastening from field to field, than in deep woods. None breed here.

68. Dendroica Blackburnice Baird. Blackburnian Warbler. Not very uncommon. Arrives about the middle of May. A few probably breed, having taken it here June 24th. Most common in mixed or hard wood forests. Thẻ nest was found in the eastern part of the State some years since, by Dr. Brewer. (Aud. Orn. Biog., vol. v., 73.)

69. Dendroica castanea Baird. Bay-breasted Warbler. Very rare. Have taken it May 20th and May 25th. One taken in July, 1862, by B. Hosford.

70. Dendroica pinus Baird. Pine Warbler. Very common, breeding plentifully. This is the earliest warbler to arrive in spring, except perhaps $D$. palmarum, and remains till the second week of October. In 1861, they were common in the pine woods April 4th, though the ground was covered with several inches of snow, some of which remained for a week after their arrival. During the last 
weeks of $\mathrm{A}$ pril and the early part of May they frequent open fields, obtaining much of their food from the ground, associating with $D$. palmarum, and at this time closely resembling it in habits. A little later they retire to the pine forests, where they almost exclusively remain during summer, keeping mostly in the tops of the taller trees. During a few weeks, about October first, they again come about the orchards and fields.

71. Dendroica pennsylvanica Baird. Chestnut-sided Warbler. Common. Arrives about May 9th, and many spend the summer and breed. Mostly frequents, in the breeding season, low woods and swampy thickets, nesting in bushes, and is not generally found much in high trees. Leaves early in September.

72. Dendroica striata Baird. Black-poll Warbler. Abundant spring and autumn visitant. Arrives the latest of the Warblers in spring, seldom being seen before May 20 th, and remains till June 1st. None breed. In fall becomes common the latter part of September, and remains till the last of October.

73. Dendroica astiva.Baird. Yellow Warbler. Summer Yellow Bird. Abundant summer visitant, arriving* early in May, and breeds in great numbers among the willows of river meadows, and among the fruit and ornamental trees of the city. Does not frequent the woods, and in many localities is rare, except in May, seeming to prefer the vicinity of water courses and alluvial meadows.

74. Dendroica maculosa Baird. Black and Yellow Warbler. Spotted Warbler. Common spring and autumn visitant. Seen in spring from May 15 th to June 1st, and in autumn as late as September 20th. Does not breed here.

75. Dendroica tigrina Baird. Cape May Warbler. Very rare. Took a single male May 15th, 1863. Has been taken at East Windsor Hill, Conn., by Dr. W. Wood.

76. Dendroica palmarum Baird. Yellow Red-poll Warbler. Common in spring from the first or second week of April to the middle of May, frequenting, in company with $D$. pinus, the edges of thickets, orchards, and open fields, and is much on the ground. Is not seen in summer, but becomes common again the last week of September, and is seen throughout October, and sometimes 
the first week of November, remaining the latest of all the Warblers. Is sometimes seen in spring before the snow is gone.

77. Dendroica discolor Baird. Prairie Warbler. Usually very rare, but was rather common in May, 1862. Have not known it detected here in summer, though it breeds in other parts of the State. The region is not of the kind they appear partial to, rather preferring rocky barrens, with scattered, dwarfish cedars and pines. Its habits are peculiar, and its notes are very much so.

Of the twenty-two species of Dendroica inhabiting the United States, thirteen have been found at Springfield, and one other (D. coerulea) may occur as accidental or extremely rare. Four of them (D. virens, pinus, pennsylvanica, astiva) are known to breed here, and two others (D. Blackburnice, castanea) have been taken in the breeding season. None are permanent residents, and none are seen in the winter. The remaining five (D. coronata, striata, maculosa, tigrina, palmarum) are at present known merely as spring and autumn visitants. D. coronata is most abundant; striata next so; virens, canadensis, maculosa, asti$v a$ and palmarum are but little less common; Blackburnice is more rare; castanea and discolor are quite rare, while tigrina is extremely rare. The earliest to arrive are pinus and palmarum, commonly appearing early in A pril ; striata is rarely seen before May 30 th ; the others commonly arrive from May 5 th to $12 \mathrm{th}$, and stragglers remain till June. $D$. coronata is decidedly gregarious in its migrations, and is everywhere about equally abundant. The others are usually seen in small parties, and keep pretty closely to the woods, except $D$. cestiva and palmarum, cestiva being never found in the deep woods.

78. Wilsonia* pusilla Bonap. Black-capped Flycatching Warbler. Rare. Have taken it May 12th to the 18th, and August 23d. Probably breeds. Generally found in swampy thickets.

Probably the Hooded Flycatching Warbler (Wilsonia mitrata Bonap.) will yet be found here.

* The prior use of Wilsonia in Botany does not appear to me to be sufficient reason for discarding its use in Ornithology. 
79. Euthlypis canadensis Cabanis. (Myiodioctes canadensis Aud.) Canada Flycatching Warbler. Common spring and autumn visitant, frequenting all woody situations. Arrives May 12th to 20th, and stragglers are seen till June $3 d$; returns about the first week of September. Has been found breeding at Lynn, Mass., by George Wells. (Dr. T. M. Brewer, Proc. B. S. N. H., vol. vi., p. 4.)

80. Setophaga ruticilla Swain. Redstart. Very common in all wooded places during the greater part of May, and for two or three weeks about September 1st. A very few breed, but the greater part retire to the mountains or northward.

81. Pyranga rubra Vieill. Scarlet Tanager. Rather common summer visitant, in high open woods, where it breeds. Occasionally visits open fields, and have known a pair nest in an apple tree, remote from any forest. Arrives about May 15th, and leaves early in September. Gathers its insect food almost wholly among the foliage of the forest trees.

82. Hirundo horreorum Barton. Barn Swallow. Very abundant from about May 1st to September 1st. A few usually seen the last week in April; stragglers often seen till the middle of September. One season knew some Barn Swallows to take possession of the nest of a pair of Cliff Sivallows, placed as usual under the eaves of a barn, driving off the Cliff Swallows; the next year they built a nest themselves under the eaves, in place of the old one that had fallen down. Have known Barn Swallows to attempt to build in the same place since, butafter persistent efforts generally fail, and take to their old quarters inside the barn.

83. Hirundo lunifrons Say. Cliff Swallow. "Eave Swallow." About equally common with the preceding; arrives commonly a few days later, and leaves a week earlier. Nests under the eaves of buildings.

84. Hirundo bicolor Vieill. White-bellied Swallow. Not very common; apparently least abundant of the Swallows, while in some of the maritime parts of the State it is the most abundant, arriving in numbers the second week in April.

85. Cotyle riparia Boie. Bank Swallow. Common, ESSEX INST. PROCEED. VOI. IV. I. 
arriving about the second week of May; leaves last of August. Arrives the latest, and leaves the earliest, of the Swallows. Breeds in communities.

86. Progne purpurea Boie. Purple Martin. Not abundant. Arrives early in May ; leaves last of August.

All the Hirundines are gregarious during the latter part of summer, and at other times as much so as the duties of incubation will admit.

87. Ampelis garrulus Linn. Bohemian Wax-wing. Winter visitant. Accidental. One was taken a few years since a few miles south of this city.-(East Windsor Hill, Ct.-Dr. W. Wood.)

88. Ampelis cedrorum Baird. Cedar Bird. Cherry Bird. "Wax-wing." Abundant during the summer. Is quite irregular and roving in its habits; seen here at nearly all seasons. Seems to be influenced in its wandering: by the supply of food rather than by climate, having observed it in Cambridge in every winter month, where it is often excessively abundant in February and Narch, feeding on cedar, ash, and hawthorn berries. Are also found in winter along the south side of Mount Holyuke. (C. W. Bennett.) Have observed them often in February and March at Springfield, but they are not common settled visitors till late in May. Seldom begins nesting before the 15 th or 20th of June, often laying its first eggs as late as the 25 th ; have seen the young of the second brood scarcely fledged September 12th. In May they gorge themselves to excess with the petals and stamens of apple blossoms, and generally depend on the smaller fruits for sustenance; they also take many insects, darting from a perch upon them, like the Flycatchers, and towards the end of summer hunt them in the air for half an hour together, pursuing them like the Swallows, but more clumsily, and apparently for amusement rather than from necessity. Gregarious at all seasons, but seen in smaller parties while breeding.

89. Collyrio borealis Baird. Great Northern Shrike. Butcher Bird. Regular winter visitant, but not very common. Seen from last of October to middle of April.

90. Vireo (Vireosylvia) olivaceus Vieill. Red-eyed Vireo. Abundant, breeding in open woods everywhere, generally fixing its nest to bushes and saplings, four to 
ten or twelve feet from the ground. Arrives about May 5 th, and is common till the last week of September. Most abundant of the Vireos; as numerous as all the others together.

91. Vireo gilvus Bonap. Warbling Vireo., Common. Arrives first week in May and remains till last week of September. Frequents orchards and gardens, and is very common among the shade trees of the city, but is very rarely seen about woods or thickets. Continues its song throughout the season.

92. Vireo (Lanivireo) solitarius Vieill. Solitary Vireo. Quite rare. Probably some breed. Arrives in spring about May 1st. Frequents open woods.

93. Vireo (Lanivireo), Aavifrons Vieill. Yellow-throated Vireo. Rather common, and breeds. Arrives second week in May. Frequents open woods and the shade trees of the city.

Have never known the White-eyed Vireo ( $V$. noveboracensis Bonap.) taken here, and if occurring, as it very probably does, being not very uncommon in the eastern parts of the State, must be excessively rare. In above a thousand specimens of the smaller land birds taken at Springfield during the last three years, by different collectors, not a single White-eyed Vireo has been found. Vireo philadelphicus Cass. may also occur, having been taken the past season at Waterville, Me., by Prof. C. E. Hamlin. (A. E. Verrill.)

Of the thirteen species of Vireo described by Prof. Baird as inhabiting the United States, only three ( $V$. olivaceus, gilvus, flavifrons) are at all common here, but one other ( $V$. solitarius) occurs, and perhaps two more ( $V$. noveboracensis and philadelphicus) will yet be detected here. All but $V$. philadelphicus, of the above mentioned, are known to breed within the State. $V$. olivaceus is rarely seen outside the woods, and gilvus as rarely elsewhere, while flavifrons is common to both situations.

94. Mimus polyglottus Boie. Mocking Bird. Very rare. Appears to be its extreme northern limit. Have been known to breed in Springfield several times within five years, and in 1860 two pairs nested here. June 20th, 1860 , I found a nest containing three freshly laid eggs, 
incubation not having been begun. Locality, a sandy field growing up to pitch pines, in one of which the nest was placed, about three feet firom the ground. The pair was secured, with the nest and eggs.

95. Galeoscoptes carolinensis Cab. (Mimus carolinensis Gray). Cat Bird. Very abundant, breeding in hedges, thickets and swamps everywhere. Arrives the last week in April; leaves about middle of October.

96. Harporhynchus rufus Cab. Brown Thrush. Brown Thrasher. Abundant summer visitant. Breeds in hedges and thickets, occasionally in fields, near woods or thickets. The nest is very generally placed on the ground; very rarely in bushes, one to three feet from the ground. Among scores of nests I have seen liere, only three were placed in bushes, though most authors describe it as always nesting: in bushes. But whether the nest is placed on the ground or in bushes may depend upon the nature of the soil, as many birds vary the situation of their nest according to circumstances. Those nests I have observed on the ground have all been in dry and sandy, and consequently warm, localities, favorable for nesting in such a manner: while in some cases where the nest has been found in bushes the ground was cold and wet. Here in the Connecticut Valley, the nest is almost universally placed on the ground, and only in a few exceptional cases in bushes.

97. Troglodytes aedon Vieill. House Wren. Summer visitant. Not very common. Breeds.

98. Troglodytes (Anorthura) hyemalis Vieill. Winter Wren. Rare spring and autumn visitant; occasional in winter. Found in swampy thickets and borders of moist woodlands. A specimen was taken in January, 1863, by Mr. B. Hosford.

All the Wrens are quite rare here, and though I have really detected no others, probably others occur very sparingly, as Telmatodytes paluistris Cab., and very possibly Cistothorus stellaris Cab., and Troglodytes americanus Aud. Dr. W. Wood has found the short-billed Marsh Wren (Cistothoms stellaris) breeding in the river marshes, at East Windsor Hill, Ct.

99. Certhia americana Bonap. Brown Creeper. Common. Resident; but most numerous in winter. Found 
mostly in high open woods, but is also common in the city. Breeds sparingly. Mr. Bradley Hosford showed me a nest of this species, June $2 \mathrm{~d}, 1863$, containing young, that apparently had been hatched some four or five days. The nest was in a large elm, in Court Square, Springfield, about ten feet from the ground, and built behind a strip of thick bark that projected in such a way as to leáve a protected cavity behind it.

100. Sitta carolinensis Gm. White-bellied Nuthatch. Resident. Very common, especially in autumn. Prefers open woods, but frequents orchards in the fall and spring.

101. Sitta canadensis Linn. Red-bellied Nuthatch. Winter visitant. Usually common; sometimes very rare. Seen in the woods from the first week in October till the last of April.

The Blue-gray Gnatcatcher (Polioptila corulea Scl.) perhaps will be found as a rare summer visitant.

102. Parus atricapillus Linn. Chickedee. Black-capped Titmouse. Resident, and abundant at all seasons. Seems to be the only Titmouse yet observed here.

103. Eremophila cornuta Boie. Shore Lark. Sky Lark. A few are seen in spring and fall.

104. Pinicola canadensis Cab. Pine Grosbeak. Winter visitant. Rare. Occurs in small parties at irregular intervals. Were seen in the winter of $1859-60$.

105. Carpodacus purpureus Gray. Purple Finch. Chiefly a spring and autumn visitant. But very few breed, and rarely stragglers are met with in the winter. Rather common in April, September and October, but are never so abundant as I have seen them at Cambridge, where, in the spring of 1863 , they were the most numerous species of bird for several weeks, occurring in flocks from March 25th to April 20th. Not uncommon in winter on Mount Holyoke.

(C. W. Bennett.)

This species seems to have greatly increased in numbers, in the last twenty-five years, in this State, as well as in other of the Eastern States, judging from the accounts of the older naturalists.

106. Astrigalinus tristis Cab. (Chrysomitris tristis Bonap.) Yellow Bird. Goldfinch. Resident. Abundant at all seasons. Breeds very late, often having unfledged 
young September 1st. Is gregarious most of the year, especially in winter, and of roving habits.

107. Chrysomitris (?) pinus Bonap. Pine Finch. Regular winter visitant, but not abundant. Arrives first or second week in October, and are seen in small parties till second or third week of May; often frequents orchards in autumn and in May to feed on a species of Aphis that infests the appletrees. A nest of this species, found in Cambridge a few years since, is in the Museum of Comparative Zoölogy.

108. Egiothus linaria Cab. Red-poll Linnet. Lesser Redpoll. Irregular winter visitant, occasionally abundant, occurring in very large flocks, as in February and March, 1860 , and again are not seen for several years.

109. Curvirostra americana Wilson. Common Crossbill. Red Crossbill. An irregular and often very abundant visitor. Though seen here at all seasons I have never been able to find it breeding. But few are generally observed here, but at intervals of several years the pine woods are found in the winter to abound with them, as in the winters of 1853-4, and 1859-60, when in February and March they were in full song; were also abundant in the spring of 1863 . Are at all times gregarious, and are sometimes seen in large flocks.

110. Curvirostra leucoptera Wilson. White-winged Crossbill. Winter visitant, occurring at irregular intervals in large flocks. Have never seen them later than April 15th. Were very abundant in 1854 and 1860 . Are much less frequent visitors than the preceeding.

111. Plectrophanes nivalis Meyer. Snow bunting. Regular winter visitant, roving about in flocks, and most numerous in severe weather. Stragglers are sometimes seen the last of October. Mr. C. W. Bennett tells me that a pair spent the summer of 1862 , and reared their young, in Springfield.

The Lapland Longspur (Centrophanes lapponicus Kaup, Plectrophanes lapponicus Selby,) may rarely oceur.

112. Passerculus savanna Bonap. Savanna Sparrow. Chiefly a spring and autumn visitant. Have never found it breeding. Not common.

113. Poøcetes gramineus Baird. Grass Finch. Bay- 
winged Sparrow. Summer visitant, breeding abundantly in open sandy fields and dry pastures. Arrives about April 1st, and remains till the first week in November. Breeds two or three times in a season, first young leaving the nest the last week of May.

114. Coturniculus passerinus Bonap. Yellow-winged Sparrow. Abundant summer visitant. Arrives about the first week in May, and leaves in autumn the earliest of the Sparrows, generally about the middle of September. Breeds in dry fields and pastures, raising two broods in the season.

115. Coturniculus (?) Henslowi Bonap. Henslow's Sparrow. Very rare summer visitant. Took a male May 18th, 1863 , and heard another in June. ' It probably occasionally breeds, as it has been found to do in other parts of the State. (Berlin, Mass.-E. S. Wheeler. Proc. B. S. N. H. vII, p. 137.-Near Lynn, Mass.-E. A. Samuels. Agr. Mass., 1863, Secy's Rep., App. p. Xxiv.)

116. Zonotrichia leucophrys Swain. White-crowned Sparrow. Rare spring and autumn visitant, possibly breeds here. Have taken it May 22d, and October 1st to 15th 1860; May 7th to June 6th 1861; and May 14th 1863. In 1861 were not very rare in May, and remained latest in spring of all those migratory Finches that do not breed here. Arrives in autumn with the White-throated Sparrow.

117. Zonotrichia albicollis Bonap. White-throated Sparrow. Common spring and autumn visitant. Seen in spring from the last week in April till May 20th; in fall from last week in September till the last week in October. Its favorite haunts, while here, are moist thickets, but is found much elsewhere. The males do not attain their mature colors till the second spring. The young males sing equally well with the adults, and probably breed in this plumage. Observing many birds singing in the garb of the female drew my attention to the subject, and dissection showed them invariably to be males. This accounts for the great proportion of birds in the livery of the female, both in spring and fall, often observed.

118. Junco hyemalis Sclater. Snow Bird. Spring and autumn visitant; a few are occasionally seen in winter. Arrives from the north about October 1st, and is abundant 
till the last of November; appears in spring early in March ; is very abundant till the middle of April, and stragglers are seen till May. Are in full song on their arrival in spring, and at all times are seen in loose flocks. While the snow is passing off in spring they seem to be more numerous than all other birds. Breed among the mountains of Berkshire County, according to Prof. Emmons, and as far south in Hampden County as Blandford and adjoining towns.

119. Spizella monticola Baird. Tree Sparrow. Common winter visitant. Seen from October 20th to about May 1st. In winter inhabits sheltered ravines and swamps, and feeds much on the seeds of weeds that remain above the snow in open fields. - Are gregarious, and when feeding, particularly in severe weather, keep up a peculiar tinkling twitter. This species was found breeding in the eastern part of the State in the summer of 1855 , its nest and eggs being found by Mr. E. Samuels. (Proc. B. S. N. H., vol. v, p. 213.)

120. Spizella socialis Bonap. Chipping Sparrow. Very common summer visitant, breeding everywhere in the vicinity of farm-houses, in the city, and even in remote fields, nesting in trees. Arrives about April 1st; leaves second or third week of October. Is not so gregarious while here as its congeners.

121. Spizella pusilla Bonap. Field Sparrow. Wood Sparrow. Common summer visitant. Breeds in old bushy fields, nesting on the ground. In one or two instances only have I found it nesting in bushes. The males sing the whole summer, and almost constantly from April till July. Arrives about April 1st, collects into loose flocks in August and September, and leaves about the middle of October. In autumn emit tinkling notes, similar to those of $S$. monticoldy.

122. Melospiza melodia Baird. Song Sparrow. Abundant summer visitant. Breeds about meadows and in moist situations. Arrives the last of March, and is extremely abundant during April, but is not properly gregarious, though occasionally found in considerable flocks when feeding; retires south late in October.

123. Helospiza Lincolnii Baird. (Melospiza Lincolnii 
Baird.) Lincoln's Sparrow. Very rare. Shot one in May, 1860, and another May 14th, 1863. No account of its previous capture in New England.*

124. Helospiza palustris Baird. (Melospiza palustris Baird.) Swamp Sparrow. Not uncommon in spring and fall, and probably some breed, though I have never taken it later than May 25th. In spring arrives first or second week in April, and appears fully as aquatic as the Water Thrush (Siurus noveboracensis Bonap.), associating with it about the margins of ponds and streams, hopping in the shallow water, and is very rarely seen away from watery situations; in autumn is found in bushy marshes and wet places, becoming common about the last week of September, and continuing till the last week of October. Said by Audubon to be abunda/nt, in vinter, about Boston.

125. Passerella illiaca Swain. Fox-colored Sparrow. Abundant in fall and spring, in small parties, scratching in thickets and moist woods. Arrives in fall October 15th; leaves last of November; appears again early in March, occasionally in February, in open winters, and leaves about April 10th. Often sings finely while here in spring, and sometimes in fall. Audubon was mistaken in saying: this species is abundant about Boston, in summer.

126. Guiraca ludoviciana Sivain. Rose-breasted Grosbeak. Summer visitant, breeding in open woods. Not abundant. Arrives May 10th to 15th. One of our most noted woodland songsters, the male occasionally singing while sitting on the nest, both sexes incubating. Nest placed in shrubs and low trees, often in evergreens, six to ten or twelve feet from the ground. Seems to have increased in numbers in the last twenty-five years, in all. parts of the State.

127. Cyanospiza cyanea Baird. Indigo Bird. Not very common summer visitant. Breeds in bushes, near gardens, orchards, edges of woods, and in bushy meadows. Arrives about the middle of May; leaves middle of September.

* Since the above was written I have taken another specimen (shot May 25th, 1864.) It was a female, and the largest eggs contained in the ovary were not bigger than a common pin's head.

ESSEX INST, PROCEFD. VOL. IV. J. 
128. Pipilo erythrophthalmus Vieill. Chewink. Towhe Bunting. Ground Robin. Very abundant summer visitant, breeding in thickets, edges of woods and swamps everywhere, nesting on the ground. Arrives last week in April; leaves second week in October. Somewlat gregarious in autumn.

129. Dolichonyx oryzivorus Swain. Bobolink. "Skunk Blackbird." Summer visitant. Arrives about May 10th. Abundant in orchards and meadows. Is scarcely gregarious in the breeding season, though many are usually found nesting in the same meadow, but begin to collect into flocks about the third week in July, at which time the old birds are beginning to moult.

130. Molothrus pecoris Swain. Cow Bird. Cow Blackbird. Abundant summer visitant. Polygamous, and more or less gregarious at all seasons. In spring and fall are sometimes seen in flocks of many hundreds, particularly in fall. Arrives first to third week in March, and commonly leaves last week in October. Dr. Brewer was mistaken in saying that the Cow Bird leaves Massachusetts before the first of July, or earlier, \&c. (See Aud. Orn. Biog., vol. v, p. 490.)

131. Agelceus phoniceus Vieill. Red-winged Blackbird. Marsh Blackbird. Summer visitant, arriving in small parties about the second and third weeks of March. Breeds plentifully, in communities, in the marshes. Rove about the country in considerable flocks during the latter part of the season, and leave the last of October.

132. Sturnella magna Swain. Meadow Lark. Common summer visitant. Breeds in meadows and moist - pastures. Arrives second or third week in March; leaves about the first week in November; a very few remain in winter. Partially gregarious, especially in autumn.

133. Icterus Baltimore Daud. Baltimore Oriole. "Golden Robin". Abundant summer visitant. Breeds plentifully in orchards and shade trees, the elm and the apple being its favorite nesting trees. Arrives about May 10th, and remains till the second week of September. In August and September hunts much in the tall deciduous woods, where it sometimes breeds, feasting, in loose, roving parties of sometimes several dozens, upon the caterpillars 
and beetles that infest the trees, and are then seldom seen in the orchards they so much frequent in the breeding season.

134. Icterus spurius Bonap. Orchard Oriole. Rare summer visitant. A few pairs breed every season.

135. Scolecophagus ferrugineus Swain. Rusty Grakle. Rusty Blackbird. Rather rare. Stragglers are seen in fall and spring; occasionally small flocks. In spring arrives early, and is seen as late as May; seen in autumn from the last week in September till November; have seen it November 24th.

136. Quiscalus versicolor Vieill. Purple Grakle. Crow Blackbird. Common summer visitant, breeding in communities, but is not generally dispersed over the country. Arrives last week in March, and earlier.

137. Corvus carnivorus Bartram. American Raven. Accidental. One was taken by Mr. C. W. Bennett, in the fall of 1859. One was killed at Tyngsborough, Mass., a few years since. (Agr. of Mass., 1859, Secy's Rep., p. 143.)

138. Corvus americanus Aud. Common Crow. Resident. Very abundant in spring and fall, appearing in immense flocks. Seems to have diminished very materially in numbers in the last six or eight years, hundreds, and probably thousands, having been killed in the State by the use of strychnine almost every year. Fewer have bred here for the last few years than formerly.

139. Cyanura cristata Swain. - Blue Jay. "Corn Bird." Common resident. Somewhat gregarious. Resides in the woods, but makes frequent excursions over the open country, visiting the orchards for piratical purposes in the summer, and the farmer's corn crib in the winter. In winter have found in its stomach the eggs of the common tent caterpillar in abundance.

140. Ectopistes migratoria Swain. Wild Pigeon. Seen in some years in great numbers; in others very rarely; are usually more or less common at all seasons, except winter, and a few generally breed. Lays but one egg at a time, but breeds tivo or three times in a summer.

141. Zencedura carolinensis Bonap. Carolina Turtle Dove. "Mourning Dove." Very common summer visi- 
tant. Often nests in orchards, and generally in low pine woods. Lays two eggs, and breeds more than once in a season. Arrives second week in March, or earlier; have seen it March 5th. Collects into loose flocks the last of July, frequenting old rye fields, and for two months is abundant, and much hunted by sportsmen, so that at all seasons it is a shy bird. The greater part leave about the 1st of October, but some remain till the second or third week.

142. Bonasa umbellus Steph. Ruffed Grouse. "Partridge." Common resident. In autumn many are taken in snares.

143. Ortyx virginiana Bonap. Quail. Resident, and now extremely rare. As late as 1851 it was quite abundant, but severe winters and sportsinen have nearly exterminated the species in this vicinity.

144. Herodias egretta Gray. White Heron. A single specimen was taken a few years since. There is a fine specimen of this species in the Springfield Museum, taken in West Brookfield, Mass., in $\mathbf{1 8 6 0 .}$

145. Ardea herodias Linn. Great Blue Heron. "Blue Crane." Regular summer visitant, breeding. Not common. Arrives early in April.

146. Ardetta exilis Gray. Least• Bittern. Extremely rare. Has been taken here. (C. W. Bennett.) Have seen specimens taken in other parts of the State.

147. Botaurus lentiginosus Steph. Bittern. "Stakedriver." Common in the marshes and river meadows. Arrives first week in April; remains till second week of October, or later.

148. Butorides virescens Bonap. Green Heron. "Shitepoke." Common. Breeds plentifully in trees in the vicinity of marshes.

149. Nyctiardea Gardeni Baird. Night Heron. "Squawk." Common. Arrives about the middle of April. In August have seen several dozens in the air at once, near their feeding grounds, soon after sunset. Are gregarious and breed in communities. Says Dr. Wood, in a letter to the writer, "I know of a swamp some fourteen miles from here [East Windsor Hill, Ct.] where thousands breed. I have counted eight nests on one maple tree. 
BIRDS OF SPRINGFIELD, MASS., ETC.

I knew two sportsmen shoot a business wagon body full one forenoon-probably two hundred."

150. Charadrius virginicus Borck. Golden Plover. Spring and autumn visitant. Not Common, except occasionally.

151. Oxyechus vociferus Reich. (AEgialitis vociferus Cass.) Killdeer Plover. Summer visitant, and breeds. Common only in particular localities.

152. AEgialeus semipalmatus Reich. (AEgialitis semipalmatus Cab.) Semipalmated Plover. Spring and autumn visitant. Not rare.

153. Plitohela minor Gray. Woodcock. Common summer visitant, arriving early in April. Breeds.

154. Gallinago Wilsonii Bonap. Wilson's Snipe. Spring and autumn visitor; sometimes abundant. Probably a few breed.

155. Pelidna americana Coues. ('Tringa alpina var. americana Cass.) Red-backed Sandpiper. Spring and anltumn visitor; not generally common.

156. Actodromas maculata Cass. (Tringa maculata Vieill.) Jack Snipe. Occasionally taken in autumn.

157. Actodromas minutilla Coues. (Tringa Wilsonii Nutt.) Least Sandpiper. Occasionally taken towards autumn ; probably occurs also in spring. Bonaparte's Sandpiper (Actodromas Bonapartii Cass.) is undoubtedly to be found here occasionally in autumn.

158. Symphemia semipalmata Hart. Willet. Spring and autumn visitant. Not common. Perhaps a few oceasionally breed.

159. Gambetta melanoleuca Bon. Greater Tell-tale Tatler. Rare spring and autumn visitant; less common than the next.

160. Gambetta favipes Bon. Lesser Tell-tale Tatler. "Yellow Legs." Spring and autumn visitant. Not uncommon.

161. Rhyacophilus solitarius Wils. Solitary Tatler. Spring and autumn visitant; not usually common.

162. Tringoides macularius Gray. Spotted Sandpiper. Summer visitant, breeding abundantly. Most common of the Gralla. 
163. Bartramia laticauda Less. (Actiturus Bartramius Bonap.) Field Plover. Bartram's Sandpiper. Summer visitant; breeds, and towards autumn is often very common.

16t. Tringites rufescens Cab. Buff-breasted Sandpiper. Rare spring and autumn visitant.

165. Rallus virginianus Linn. Virginia Rail. "Water Hen". Not common. Occasionally breeds here; a pair of young in the Springfield Museum taken here.

166. Porzana carolina Vieill. Common Rail. Sora Rail. Arrives in April, and some remain till November. Breeds, and is pretty common in September and October.

The Yellow Rail ( $P$. noveboracensis), being found in other parts of the State, may be looked for here, but only as a rare species.

167. Fulica americana Gm. Coot. Occasionally taken. Dr. W. Wood says: "I have taken five in a season. They come after most ducks have gone north, and resort to the small and inland ponds." Breed in some parts of Massachusetts.

168. Bernicla canadensis Boie. Canada Goose. "Wild Goose." Common spring and autumn visitant, but seldom seen except flying in the air. Pass to the north in March and April, and to the south in November. Have seen flocks as early as September 28th, and as late as December 10th. Were unusually abundant in the fall of 1859 . November 19 th, 1859 , between the hours of $10 \mathrm{~A}$. M. and 12 M., I noted ten flocks in a breadth of two miles, estimated (more than half being actually counted) to contain more than seven hundred geese, a remarkably large number for the length of time Probably does not breed in the State, though supposed to by Audubon.

169. Bernicla brenta Steph. Brant. Not common; seen at the same seasons as the preceding.

170. Anas boschas Linn. Mallard. Taken near here by Dr. Wood, and undoubtedly occurs here, but is very rare, as it is in all parts of the State.

171. Anas obscura Gm. Black Duck. Abundant. Arrives in March and remains till May; becomes common again in September and remains till late in November; a few sometimes seen in winter. Our most common Duck. Breeds in the mountainous parts of Western Massachusetts. 
BIRDS OF SPRINGFIELD, MASS., ETC.

172. Dafila acuta Jenyns. Pin-tail Duck. "Sprig Tail." Rather rare winter visitant.

173. Nettion carolinensis Baird. Green-winged Teal. Common. Dr. W. Wood tells me they pass north later and return earlier than most Ducks.

174. Querquedula discors Steph. Blue-winged Teal. Common, but less abundant than the preceding.

175. Chaulelasmus streperus Gray. Gadwall. Gray Duck. Rare. Specimen in Springfield Museum taken here. Said to breed in the State, but the authority is doubtful.

176. Mareca americana Steph. American Widgeon. Bald-pate. Not very common, in spring and fall.

177. Aix sponsa Boie. Wood Duck. Summer Duck. Not an uncommon summer visitant, breeding. Arrives early in spring, and leaves late in November.

178. Aythya vallisneria Bon. Canvass-Back Duck. Very rare; found occasionally near here (Dr. Wood), and undoubtedly is to be found here. Occurs in other parts of the State. Probably the Red-head (A. americana Bon.) is also to be found here.

179. Bucephala americana Baird. Golden-eye Duck. "Whistler." "Whistle-wing." Not uncommon in winter. Dr. Wood, says it is abundant on the river in winter, but very difficult to obtain unless you are pretty familiar with its feeding grounds.

180. Bucephala albeola Baird. Buffel-headed Duck. "Butter Ball." Occasionally taken here in winter.

181. Harelda glacialis Leach. Long-tailed Duck. "South Southerly." Occasionally taken near here (Dr. Wood), and undoubtedly occurs at Springfield.

182. Melanetta velvetina Baird. Velvet Duck. Rare. Dr. Wood has taken two specimens at East Windsor Hill, Ct., and it must occur here.

183. Erismatura rubida Bon. Ruddy Duck. Rare: there is a specimen in the Springfield Museum taken here by Mr. L. Hyde.

184. Mergus americanus Cass. Sheldrake. Goosander. Common winter visitant. Said by Audubon to breed in the State, which is not improbable. 
185. Mergus serrator Linn. Red-breasted Merganser. Common winter visitant; rather more common than the preceding. Breeds in the State, according to Audubon. (Orn. Biog., vol. v, p. 93.)

186. Lophodytes cucullatus Reich. Hooded Merganser. Winter visitant; rather less common than either of the two immediately preceding.

187. Thalassidroma Leachii 'Temm. Leach's Petrel. Very rare; probably accidental; has been taken here in a few instances only. Common off the coast of the State.

188. Larus Smithsonianus Coues. (Larus argentatus Brünn.) Herring Gull. Not very uncommon at times along the river, especially in spring and fall. Abundant along our coast in autumn, winter, and early spring.

- 189. Chrococephalus Philadelphia Lawr. Bonaparte's Gull. Occasionally observed here. Common along the coast.

190. Colymbus torquatus Brünn. Great Northern Diver. "Loon." Resident, occasionally breeding. Not common.

191. Colymbus septentrionalis Linn. Red-throated D)iver. Rare winter visitant; chiefly young that are seen

192 Podiceps (Pedecethya) Holbolli Reinh. (Podiceps griseigena Gray.) Red-necked Grebe. Chiefly a winter visitant; not common. Possibly breeds, as it has been taken here the third week of May in full breeding plumage

193. Podiceps cristatus Latl. Crested Grebe. Rare winter visitant.

194. Podiceps (Dytes) cornutus Lath. Horned Grebe. Rare; chiefly young taken here. A pair was killed here a few years since, about $J$ une 1 st, in full breeding plumage.

195. Podilymbus podiceps Lawr. "Dipper Duck." Common in spring and fall.

List of Birds found in Massachusetts not observert at Springfield.

To complete a catalogue of the Birds known to exist in the State of Massachusetts, I have added, in the following list, all those known to have been obtained within the 
State that have not been noticed at Springfield. The list will be seen to consist mainly of those Water Birds that frequent the coast and are not found far inland, with a f'ew rare or accidental visitors. No species is admitted of which there is not good evidence of its capture in the State; and when the species is extremely rare, the authority is cited on which it is inserted. Consequently some species that have been attributed to Massachusetts, from their occurrence in adjoining States, though probably to be found here as rare visitors, and are thus mentioned, are not counted as a part of the list; very careful observers will, doubtless, yet detect most of them here.

1. Cathartes atratus Less. Black Vulture. Accidental. One was obtained in Swampscott, in November, 1850. (S. Jillson, Proc. Ess. Inst., Vol. I, p. 223 -Brewer's N. Am. Oölogy, pt. I, p. 5.) Another was taken the past season, Sept. 28, at Gloucester, by Mr. William Huntsford. (A. E. Verrill.)

2. Cathartes aura Ill.' Turkey Vulture. Accidental. Two were taken in the State in 1863. (E. A. Samuels, Agr. Mass., 1863, Secy's Rep, App, p. xvirr.)

3. Falco candicans Gm. Jer Falcon. Accidental in winter. One was shot at Sekonk Plains, about 1840 . (S. Jillson, Proc. Ess Inst., vol. I, p. 226.) Has been seen here by Nuttall and others.

4. Aquila canadensis Cass. Golden Eagle. Extremely rare; but few recorded instances of its capture in the State. (Lynn, S. Jillson, Proc. Ess. Inst., vol. I, p. 203. Lexington, Dr. Kneeland, Proc. B. S. N. H., vol. v, p. 272. Near Boston, Brewer, N. Am. Oöl,. pt. I, p. 45.-Upton, Agr. Mass., 1859, Secy's Rep., p. 141.)

5. Syrnium oinereum Gmelin. Great Cinerous Owl. Occasional in winter. (Marblehead, February, 1831, and January, 1835 ; S. Jillson, Proc. Ess. Inst., vol. I, p. 204.) Seven were taken in the State during the year ending: February, 18t3. (Dr. S. L. Abbot, Proc. B. S. N. H., vol. I, pp. 57 and 99.) Two specimens in the Mus. Comp. Zoilogy were obtained in 1848, in the Boston markets, and were probably killed in the State.

The Hawk Owl (Surnia ulula Bon.) is said by Prof. Emmons to have been seen in autumn. Though I have. ESSEX INST. PROCEED. VOL. IV. K. 
found no notice of its capture, it is not improbable that it may occasionally occur along the Green Mountains in the Western part of the State.

The Banded Thrree-toed Woodpecker (Picoides hirsutus Gray) has been repeatedly attributed to the State, and may occur as a very rare or accidental winter visitor.

6. Hylotomus pileatus Baird. Pileated Woodpecker. "Log Cock." Rare. Driven from most parts of the State by the absence of extensive forests, but is still found in the wooded, mountainous parts of Berkshire County.

The Varied Thrush (Ixoreus ncevius Bon.) is said by Prof. Baird, in the Reports on the Pacific Railroad Explorations and Surveys, vol. Ix, pp. xxI and 219, to be accidental near Boston, quoting Dr. Cabot (Proc. Bost. So. N. H., vol. III, p. 17) as authority. Dr. Cabot states that a specimen of this species was obtained in Boston market, but adds that it was shot in New Jersey. This is the only notice I can find respecting this species being found in Massachusetts, either by Dr. Cabot or others.

7. Oporornis agilis Baird. Connecticut Warbler. Very rare. Was taken in Berlin, in the summer of 1845. (Dr. S. Cabot Jr., Proc. Bost. So. N. H., Vol. II, p. 63.)

8. Helmitherus vermivorus Bon. Worm-eating Warbler. Very rare. Its nest has been found in Cambridge. (Peabody's Rep. Orn. of Mass., p. 312.*)

9. Helmitherus Swainsonii Bon. Swainson's Warbler. Audubon states, on the authority of Dr. T. M. Brewer, that one was taken in Massachusetts by Mr. S. Cabot Jr. (Aud. Orn. Biog., vol. v, p. 462.) Mr. Peabody probably alludes to the same specimen (Rep. on Orn. of Mass., p. 213.) Very rare in this State.

10. Helminthophaga pinus Baird. Blue-winged Yellow Warbler. Summer visitant. Very rare. (S. Cabot Jr., Proc. B. S. N. H., vol. vi, p. 386.)

11. Helminthophaga chrysoptera Baird. Golden-winged Warbler. Summer visitant. Very rare. (S. Cabot Jr., Proc. B. S. N. H., vol. vi, p. 386.) Have seen specimens in the Mus. Comp. Zoöl., Cambridge, that were taken in the State.

* Fishes, Reptiles and Birds of Massachusetts. 
The Blue Warbler (Dendroica cœrulea Baird.) is said to be a rare summer visitant, (F. W. Putnam, Proc. Ess. Inst., vol. I, p. 207,) but I have failed to find an authentic instance of its capture in this State. Audubon says it has been taken at Pictou, Nova Scotia, and so may very naturally be expected to occur in Massachusetts.

12. Wilsonia minuta Bon. (Myioioctes minutus Baird.) Small-headed Flycatcher. This little known and rather doubtful species is said to occur in this State. (Ipswich, Dr. T. M. Brewer; Berkshire County, Prof. E. Emmons. Peab. Rep. Orn. Mass., p. 297.-Salem, T. Nuttall, Man. Orn., vol. I, p. 297.)

The Hooded Flycatcher (Wilsonia mitrata Bon.; Myiodioges mitratus Aud.) may be looked for in this State, as it has 'been found in Connecticut and New York. Mr. E. A. Samuels, in his recent list of the Birds of Massachusetts, (Agr Mass., 1863, Secy's Rep., App, p. XxII,) gives it as a rare summer visitor.

13. Pyranga cestiva Vieill. Accidental. "Two were taken in Lynn, after a severe storm, April 21st, 1852." (S. Jillson, Proc. Ess. Inst., vol. I, p. 224.)

14. Vireo noveboracensis Bon. White-eyed Vireo. Summer visitant. Not very uncommon in the eastern part of the State, where it breeds.

15. Cistothorus (Telmatodytes) palustris Cabanis. Marsh Wren. Summer visitant. Rare.

16. Cistothorus stellaris Cab: Short-billed Marsh Wren. Summer visitant. Not uncommon.

The Blue Gray Gnatcatcher (Polioptila corulea Sclat.) is said by Peabody to be found in Massachusetts, on the authority of Dr. Brewer, (Rep., p. 297.) Having been found in adjoining States,-in New York north of the latitude of Boston, as well as in Nova Scotia, and in Connecticut,-it may be looked for as a rare straggler from its usual habitat. I have been unable as yet to learn of its actual capture in this State.

The Crested Chickadee (Lophophanes bicolor Bonap.) though mostly a southern species, Audubon states (Orn. Biog., vol. v, p. 472) is common in Nova Scotia, and hence may be expected to occur here.

17. Parus hudsonicus Forster. Hudsonian Titmouse. 
Occasional or accidental in winter. (Brookline, S. Elliot Green, Peabody's Rep., p. 402.) Resident at Calais, Maine, but not common. (G. A. Boardman, Proc. B. S. N. H., vol. IX, p. 126.)

18. Centrophanes lapponicus Kaup. Lapland Longspur. Winter visitant. Occasional, or accidental. (F. W. Putnam, Proc. Ess. Inst., vol. I, p. 210.)

19. Ammodromus maritimus Swain. Sea-side Finch. Summer visitant. Common in the salt marshes along the coast, where it breeds.

20. Ammodromus caudacutus Swain. Sharp-tailed Finch. Common summer visitant in salt marshes, where it breeds. Have taken it in the marshes of Charles River the last week in October.

21 Chondestes grammaca Bon. Lark Finch. Accidental. "One found in Gloucester, about 1845." (S Jillson, Proc. Essex Inst., vol. I, p. 224.)

22. Euspiza americana Bon. Black-throated Bunting. Probably rare or occasional. Said to be found here by Nuttall (Man. Orn., vol. I, p. 461). According to Peabody, "is found in high meadows near salt water marshes, from the middle of May till the last of August." (Rep. Orn. of Mass., p. 319.) Mr. E. A. Samuels informs me that he has seen two specimens killed in this State; one was sent him from Woburn. Nuttall, in his account of the notes and habits of this species, as observed here, has described the peculiar song and habits of the Yellow-winged Sparrow (Coturniculus passerinus Bon.) with remarkable aptness, which species he evidently mistook for the Blackthroated Bunting. Nuttall seems not to have known the Yellow-winged Sparrow, under its proper name, at the time he wrotê, and it is difficult to tell what he had in mind when describing its habits and distribution in the breeding season; his description of its song, which he strangely likens to that of the Purple Finch, and of its eggs, being not at all applicable to the Yellow-winged Sparrow. As Nuttall has been the authority chiefly depended on for the occurrence of Euspiza americana in this State, I strongly doubted its having been taken here, till assured of the fact by Mr. Samuels.

The Blue Grosbeak (Guiraca ccerulea Swain.) may be 
looked for as an occasional visitor. Has been found at Calais, Maine, where it is "very uncertain, but common in the spring of 1861." (G. A. Boardman, Proc. B. S. N. H., vol. Ix, p. 127.)

23. Cardinalis virginianus Bon. Cardinal. Red Bird. Accidental summer visitant, according to Nuttall. (Man. Orn., vol. I, p. 519.) Seen "only at irregular intervals, in the villages on the Connecticut river." (Peabody, Rep. Orn. Mass., p. 329.)

24. Quiscalus major Vieill. Boat-tailed Grakle. Accidental. Have heard of one that was killed in Cambridge a few years since. Mr. E A. Samuels tells me that a pair bred in Cambridge in 1861.

25. Corvus ossifragus Wils. Fish Crow. An occasional visitor along the southern coast of the State.

26. Tetrao canadensis Linn. Spruce Partridge. Accidental. Found in the hemlock woods of Gloucester, in September, 1851. (S. Jillson, Proc. Ess. Inst., vol. I, p. 224.)

27. Cupidonia cupido Baird. Pinnated Grouse. Prairie Hen. Nearly extinct in Massachusetts. A few are occasional visitors in the southeastern part of the State, from Long Island, where they still remain. (S. Cabot Jr., Proc. B. S. N. H., vol. v, p. 154.) About thirty years since were quite common in Martha's Vineyard (Audubon Birds Amer., vol. v, p. 101.)

The Wild Turkey (Meleagris gallopavo Linn.) is now probably extinct in this State. Within a few years it has been said to occur wild on Mts. Tom and Holyoke; but I can find no authentic instancs of its recent capture in this State. The accounts of those recently taken seem to rest on the authority of hunters, who might readily mistake a stray domestic turkey for a wild one, and not on the authority of reliable naturalists. It is well known that the domestic turkey will sometimes take to the woods, assuming the habits of the wild bird; hence these reports may well be received with considerable caution. In winter the wild birds are found in Boston markets, but are brought from distant parts of the country, chiefly from the West.

28. Garzetta candidissima Bonap. Snowy Heron. Ac- 
cidental. Stragglers have been taken in a few instances. Have seen one that was killed near Boston, in 1862.

29. Florida ccerulea Baird. Blue Heron. Stragglers only taken here. There is a specimen in the State Agricultural Cabinet, taken in the eastern part of the State.

30. Ibis Ordii Bonap. Glossy Ibis. Occasional; apparently accidental. Have been taken here at irregular intervals. In June, 1830, three were obtained in the eastern part of the State. (Nuttall, Man. Orn., vol. II, p. 88.) Others have been taken. (Cabot, Proc. B. S. N. H., vol. III, pp. $313,333,355$; vol. IV, p. 346.$)$

hel- $>$ 31. Octhodromus Wilsonius Reich. (AEgialitis WilsoBlack-nius Cass.) Wilson's Plover. Occasional in summer. Inrer. serted on the authority of Dr. Brewer, who found them, Inrt, x. according to Peabody (Rep. Orn. Mass. p. 360), "abundant at Nahant, in August," 1838.

32. AEgialeus melodus. (AEgialitis melodus Cab.) Piping Plover. Common visitant, mostly along the seacoast in summer, some breeding.

33. Hcematopus palliatus Temn. Oyster Catcher. Very rare. Has been found in the State by Dr. Brewer. (Peab. Rep. Orn. Mass., p. 358.)

34. Strepsilas interpres Ill. Turnstone. Common spring and autumn visitant, along the coast.

The American Avoset (Recurvirostra americana Gmel.) and the Black-necked Stilt (Himantopus nigricollis Vieill.), from their general distribution, may be looked for in Massachusetts as very rare species.

35. Phalaropus Wilsonii Sab. Wilson's Phalarope. Very rare. Found in the State by Audubon. (Birds Am., vol. v, p. 301.)

36. Phalaropus hyperboreus Temn. Northern Phalarope. Along the coast; not common.

37. Phalaropus fulicarius Bon. Red Phalarope. Occasional visitor, chiefly along the coast, in spring and autumn.

38. Macrorhamphus griseus Leach. Red-breasted Snipe. Not very common. Spring and autumn visitant, near the coast.

39. Tringa canutus Linn. Ash-colored Sandpiper. 
Knot. "Gray Back." Spring and fall; sometimes very abundant in autumn, arriving in August.

40. Arquatella maritima Baird. (Tringa maritima Brünn.) Purple Sandpiper. "Rock Snipe." On the coast in autumn; not generally common.

41. Ancylochilus subarquata Kaup. Curlew Sandpiper. Coast; not common.

42. Actodromas Bonapartii Cass. (Tringa Bonapartii Schl.). Bonaparte's Sandpiper. Coast in spring and fall ; sometimes abundant.

43. Ereunetes pusilla Cass. Semipalmated Sandpiper. Common along the coast in spring and autumn.

44. Limosa fedoa Ord. Marbled Godwit. Rare passenger in spring and fall.

45. Limosa hudsonica Swain. Hudsonian Godwit. Spring and fall. Not common.

46. Numenius longirostris Wilson. Long-billed Curlew. Spring and fall. Not common.

47. Numenius hudsonius Lath. Hudsonian Curlew Rare. Spring, fall and winter.

48. Numenius borealis Lath. Esquimaux Curlew. Spring and fall; occasionally in winter on the coast. Rare.

49. Rallus crepitans Gm. Clapper Rail. Rare or accidental. (S. Cabot Jr., Bost. So. N. H., vol. III, p. 326.)

50. Porzana noveboracensis -? Yellow Rail. Found in spring and fall; perhaps breeds. Not common.

51. Gallinula galeata Bonap. Florida Gallinule. Accidental. Has been taken at Fresh Pond, Cambridge, by. Mr. Cabot. (Peab. Rep. Orn. Mass., p. 258.)

52. Gallinula martinica Lath. Purple Gallinule. Like the preceding, occurs as a very rare, chance visitor from the south, but is oftener met with. Has been taken but a few times in this State.

53. Anser hyperboreus Pallas. Snow Goose. Winter visitant. Not common.

54. Anser Gambellii Hartl. White-fronted Goose. Have seen specimens obtained in Boston market that were probably taken in the State.

55. Bernicla Hutchinsii Bonap. Hutchin's Goose. 
This species is introduced as a bird of Massachusetts with considerable doubt. For its occurrence here, we have the authority of Nuttall, (Man. Orn., vol. II, p. 362) who mentions it as a straggler on our coast, - and of Giraud, who says it is quite abundant some seasons on the coast of Massachusetts. Lindsley, in his Catalogue of the Birds of Connecticut, (Am. Jour. Sc. and Arts, vol. xurv, p. 249) says it is not unfrequently taken in Connecticut in spring.

56. Bernicla leucopsis -? (Anser erythropus Linn.) Barnacle Goose. Is said to have been shot at Quincy, Mass., by Dr. S. Cabot Jr., (Proc. B. S. N. H., vol. III, p. 136.) Prof. Baird says, "its occurrence in North America is very doubtful, resting only on very insufficient evidence. (P. R. R. Ex. and Surv., vol. Ix, p. 768.)

57. Nettion crecca Kaup. English Teal. Accidental from Europe. Has been taken in the State. (Dr. H. Bryant, Proc. B. S. N. H., vol. v, p. 195.)

58. Spatula clypeata Boie. Spoonbill. Shoveller. Not uncommon. Chiefly seen in spring and fall.

59. Mareca penelope Bon. European Widgeon Has been taken at several points along the eastern coast of the United States, and has been found apparently breeding on Long Island, (Dr. T. M. Brewer, Proc. B. S. N. H, vol. vi, p. 419) where it has been repeatedly found. One has been taken in this State. (E. A. Samuels.)

-60. Fulix marila Baird. Scaup Duck. Black-headed Duck. "Blue Bill." Not common. Found chiefly in spring and autumn; occasionally in winter.

61. Fulix affinis. Baird. Little Black-headed Duck. Spring and fall. Not common.

62. Fulix collaris Baird. Ring-necked Duck. Spring and autumn. Rare.

63. Aythya americana Bon. Red-headed Duck. "Redhead." Autumn and winter. Not very common. Abundant in the markets of Boston in winter, but, like the Canvassbacks, are brought from the bays and rivers of the Middle States

64. Histrionicus torquatus Bonap. Harlequin Duck. Winter visitant. Not common.

65. Camptolcemus labradorius Gray: Lyabrador Duck. Rare winter visitant. 
66. Pelionetta perspicillata Kaup. Surf Duck. Common in fall and spring, and some remain through the winter.

67. Oidemia americana Swain. Scoter. Autumn and winter. Not uncommon; often abundant.

68. Somateria mollissima Leach. Eider Duck. Not uncommon in winter.

69. Somateria spectabilis Leach. King Eider. Rare visitant in winter.

The Smew (Mergellus albellus Selby) Mr. E. A. Samuels attributes to this State, having seen a specimen which he was told was taken in Massachusetts Bay.

The American Pelican (Pelecanus erythrorhyncus Gmelin) has recently been taken at Calais, Me., (G. A. Buardman, Proc. B. S. N. H., vol. Ix, p. 130) and, according to DeKay, was formerly numerous on the Hudson and other rivers and lakes of New York. It probably occurs as a chance visitor in this State.

70. Sula bassana Ross. Gannet. Occasional on the sea coast in fall and winter.

71. Graculus carbo Gray. Common Cormorant. "Shag." Common near the coast in fall and winter.

72. Graculus dilophus Gray. Double-crested Cormorant. Not uncommon near the coast in winter.

73. Procellaria glacialis Linn. Fulmar Petrel. Spring and autumn visitant.

74. Thalassidroma Wilsonii Bon. Wilson's Petrel. Not uncommon off the coast. Have seen specimens taken near Chelsea Beach.

75. Thalassidroma pelagica Bon. Mother Cary's Chicken. Rare, off the coast, as far south as Provincetown. (E. A. Samuels.)

76. Puffinus major Bon. Greater Shearwater. Not common. Off the coast in winter.

77. Puffinus fuliginosus Strick. Sooty Shearwater. Coast in autumn and winter. Not common.

78. Puffinus anglorum Temn. Mank's Shearwater. Rare, off the coast in winter.

ESSEX INST. PROCEED. VOL. IV. I. 
79. Stercorarius pomarinus Temn. Pomarine Jager. Massachusetts Bay. Rare in winter.

80. Stercorarius parasiticus Temn. Arctic Jager. Massachusetts Bay in winter. Not common.

81. Stercorarius cepphus Lawr. Buffon's Skau. Rare. Has been taken near Boston.

82. Larus marinus Linn. Black-backed Gull. Not a common winter visitant.

83. Larus delawarensis Ord. Ring-billed Gull. Not very uncommon near the coast in winter.

84. Larus leucopterus Fabr. White-winged Gull. Rare winter visitant.

85. Chroecocephalus atricilla Lawr. Laughing Gull. Winter. Not common.

86. Rissa tridactyla Bon. Kittiwake Gull. Very common about the islands in Massachusetts Bay in autumn and winter.

The Fork-tailed Gull (Xema Sabinii Bonap.) may occur on our coast as an occasional visitor.

87. Sterna aranea Wils. Marsh Tern. Rare summer visitor. (E. A. Samuels, Agr. Mass. 1863, Sec's Rep. App., p. xxix.)

88. Sterna fuliginosa Gm. Sooty Tern. Rare summer visitor. (F. A. Samuels, Agr. Mass., 1863, Secy's Rep., App., p. xxix.) Mr. Samuels informs me that it breeds on Muskegat Island, near Martha's Vineyard.

89. Sterna hirundo Linn. Wilson's Tern. Common in summer, breeding on the rocky islands in the Bay.

90. Sterna macroura Naum. Arctic Tern. Common. Chiefly a winter visitant. Sometimes breeds.

91. Sterna paradisea Brünn. Roseate Tern. Very rare; perhaps merely accidental; from the south in summer. Several instances known of its capture in the State. (Chelsea Beach, Nuttall, Man. Orn. vol. II, p. 278.-Beverly, Mass., 1847, S. Cabot Jr., Proc. B. S. N. H. vol. II, p. 248.- Have seen a specimen taken off our coast a few years since.

92. Sterna frenata Gambel. Least Tern. Spring and 
autumn visitant. Not common. Occasional in summer.

Other species of Sterna undoubtedly occur as rare visitors off our coast, as the Caspian Tern (Sterna caspia Pall.) in winter, from the north; and possibly, at the same season, Trudeau's Tern (Sterna Trudeauii Aud.) as a very rare, or accidental species.

93. Hydrochelidon fissipes Gray. (Hydrochelidon plumbea Wils.) Short-tailed Tern. Not common. Have seen specimens taken near Chelsea Beach.

94. Colymbus arcticus Linn. Black-throated Diver. rare autumn and winter visitor.

95. Utamania torda Leach. Razor-billed Auk. Not uncommon on the coast in autumn and winter.

96. Mormon arctica Ill. Arctic Puffin. Not uncommon in winter.

97. Uria grylle Lath. Black Guillemot. Not very uncommon winter visitant.

98. Cataracles troile Bryant. Foolish Guillemot. Murre. Not uncommon in winter, and perhaps a few breed.

99. Cataractes ringvia Bryant. Murre. Common in winter.

100. Cataractes lomvia Bryant. (Uria arra Pall.) Thick-billed Guillemot. Murre. Rather common in winter.

101. Mergulus alle Vieill. Little Auk. Sea Dove. Rather rare winter visitant. Has been taken on the Connecticut, at Greenfield, Mass., in one instance.

The birds found in Massachusetts may be conveniently grouped into the following classes: 1. Species that regularly breed in the State. II. Resident species. III. Winter visitants. IV. Spring and autumn visitants. V. Summer visitants. VI. Accidental or irregular visitants.

\section{Species that regularly breed in the State.}

Those marked with a star, though repeatedly found breeding in some localities, breed rery sparingly, and not generally over the State. Some others are common in some parts of the State, but are unknown or very rare 
in most parts. Several others have been known to breed, but apparently only accidentally, as in the case of Chrysomitris pinus, Spizella monticola, and a few others. A few not in the list may occasionally breed.

1. Falco anatum Bonap.*

2. Tinnunculus sparverius Vieill.*

3. Accipiter Cooperii Bonap.

4. " fuscus Bonap.

5. Buteo borealis Vieill.

6. " lineatus Jard.

7. “ pennsylvanicus Bon.

8. Circus hudsonius Vieill.

9. Haliætus leucocephalus Sav.*

10. Fandion carolinensis Bon.*

11. Bubo virginianus Bonap.

12. Scops asio Bunap.

13. Otus americanus Bonap.

14. Brachyotus Cassinii Brewer.

15. Syrnium nebulosum Gray.

16. Nyctale acadica Bonap.

17. Coccygus americanus Bon.

18. " erythrophthalmus Bon.

19. Picus villosus Linn.

20. " pubescens Linn.

21. Sphyropicus varius Baird.

22. Hylotomus pileatus Baird.*

23. Melanerpes erythrocephalus $\boldsymbol{S} \boldsymbol{w}$.*

21. Colaptes auratus Swain.

25. Trochilus colubris Linn.

26. Chætura pelasgia Steph.

27. Antrostomus vociferus Bon.

28. Chordeiles popetue Baird.

29. Ceryle alcyon Boie.

30. Tyrannus carolinensis $B d$.

31. Myiarchus crinitus $C a b$.*

32. Sayornis fuscus Baird.

33. Cuntopus borealis Baird.

34. " virens $\mathrm{Cab}$.

35. Empidonax Traillii Baird.

36. " minimus $B d$.

37. “ acadicus $B d$.

38. Turdus mustelinus Gmelin.

39. “ Pallas\$í Cubanis.*

40. " fuscescens Steph.

41. " migratorius Linn.

42. Sialia sialis Baird.

43. Mniotilta varia Vieil?.

44. Parula americana Bcn.

45. Geothly pis trichas $C a b$.

46. Icteria viridis Bon.*

47. Helmitherus vermivorus Bon.*

43. Helıninthophaga ruficapilla $B d$.

49. Siurus aurocapillus Swain.

50. “ noveboracensis Nutt.

51. Dendroica virens Baird.
52

53.

54.

55.

56.

57.

58.

59.

60.

61.

62.

63.

64.

65.

66.

67.

68.

69.

70.

71.

72.

73.

74.

75.

76.

77.

78.

79.

Astrigalinus tristis Cabanis.

81. Passerculus savanna Bon.

82. Poœcetes gramineus Baird.

83. Coturniculus passerinus Bon.

84. “ Henslowii Bon.*

85. Ammodromus caudacutus $S w$.

86.

87.

88. Spizella pusilla Bonap.

89. " socialis Bonup.

90. Melospiza melodia Baird.

91. Helospiza palustris Baird.

92. Guiraca ludoviciana Swain.

93. Cyanospiza cyanea Baird.

94. Pipilo erythrophthalmus Vieill.

95. Dolichonyx oryzivora Swain.

96. Molothrus pecoris Swainson.

97. Agelæus phœniceus Vieill.

98. Sturnella magna Swain.

99. Icterus spurius Bon.*

100. “Baltimore Bon.

101. Quiscalus versicolor Vieill.

102. Corrus americanus $\boldsymbol{A} u d$. 
103. Cyanura cristata $\boldsymbol{S} w$.

104. Ectopistes migratoria $S w$.

105. Zenædura carolinensis Bon.

106. Cupidonia cupido Baird.*

107. Bonasśa umbellus Steph.

108. Ortyx virginianus Bonap.

109. Ardea herodias Linn.

110. Ardetta exilis Gray.

111. Botaurus lentiginosus Steph.

112. Butorides virescens Bon.

113. Nyctiardea Gardeni Baird.

114. Oxyechus vociferus Reich.

115. Egialeus melodus Reich.

116. Squartarola helvetica Cuv.

117. Philohela minor Gray.
118. Gallinago Wilsonii Bonap.

119. Symphemia semipalmata Hartl.

120. Tringoides macularius liray.

121. Bartramia laticauda Less.

122. Rallus virginianus Linn.

123. Porzana carolina Vieill.

124. Fulica americana $\mathrm{Gmel}_{\text {.* }}$

125. Anas obscura Gmel.*

126. Mergus americanus Cass.*

127. " serrator Linn.*

128. Aix sponsa Boie.

129. Thalassidroma Leachii Temm.

130. Sterna hirundo Linn.

131. " macroura $\mathcal{N a u m}$.

\section{I. Resident Species. Su/. 98}

Of a few species more properly to be regarded as spring and autumn or summer visitors, a few individuals are sometimes found in winter, as of Ceryle alcyon, Turdus migratorius, Melospiza melodia, \&c., but since the Inajority are migratory, they are not placed in the list of resident species.

1. Falco anatum Bon.

2. Tinnunculus sparverius Vieill.

3. Buteo borealis Vieill.

4. Circus hudsonins Vieill

5. Haliætus leucocephalus Savigny.

6. Bubo virginianus Bonap.

7. Scops asio Bonap.

8. Otus americanus Bon.

9. Brachyotus Cassinii Brew.

10. Syrnium nebulosum Gray.

11. Nyctale acadica Bonap.

12. Picus villosus Linn.

13. " pubescens Linn.

14. Hylotomus pileatus Baird.
15. Certhia americana $B u n$.

16. Sitta carolinensis Gmel.

17. Parus atricapillus Linn.

18. Astrigalinus tristis $\mathrm{Cab}$.

19. Corvus americanus $\boldsymbol{A} u d$.

20. Cyanura cristata Swain.

21. Cupidonia cupido Baird.

22. Bonasa umbellus Steph .

23. Ortyx virginiana Bonap.

24. Fulica americana Gmel.

25. Anas obscura Linn.

26. Mergus americana Cass.

27. “ serrator Linn.

28. Colymbus torquatus Brunn.

\section{Winter Visitants.}

Those species marked with a star are occasional or irregular visitors, but some of them sometimes occur in great abundance. A few individuals are often found in winter of some of those species properly to be considered as spring and autumn visitants, and as such are placed in the next list below.

1. Astur atricapillus Bon.

2. Archibuteo lagopus Gray.

3. "Sancti-Johannis $G r$.

4. Aquila canadensis Cass.*

5. Syrnium cinereum $\boldsymbol{A} u d$. $^{*}$

6. Nyctale Richardsonii Bon.*

7. Nyctea nivea Gray.

8. Picoides arcticus Gray.*

9. Regulus satrapa Licht.

10. Ampelis garrulus Linn.*
11. Collyrio borealis Baird.

12. I'roglodytes hyemalis Vieill.

13. Sitta canadensis Linn.

14. Parus hudsonicus Forst.*

15. Eremophila cornuta Boie.

16. Pinicola canadensis $\mathrm{Cab}$. $^{*}$

17. Chrysomitris pinus Bonap.

18. Curvirostra americana Wils.

19. " leucoptera Wils.*

20. Egiothus linaria $\boldsymbol{C} a b$.* 
21. Plectrophanes nivalis Meyer.

22. Centrophanes lapponicus Kaup.*

23. Spizella monticolof Baird.

24. T'etrao canadensis Linn.*

25. Arquatella maritima Baird.

26. Anser hyperboreus Pallas.

27. " Gambellii Hartl.

28. Dafila acuta Jenyns.

29. Bucephala americana Baird.

30. “ albeola Baird.

31. Histrionicus torquatus Bon.

32. Camptolæmus labridorius $\boldsymbol{G} r$.

33. Melanetta velvetina Baird.

34. Pelionet ta perspicillata Kaup.

35. Oidemia americana Swain.

36. Somateria mollissima Leach.

37. “ spectabilis Leach.

38. Erismatura rubida Bonap.

39. Lophodytes cucullatus $R \in i c h$.

40. Sula bassana Briss.

41. Graculus carbo Gray.

42. “ dilophus Gray.

43. Puffinus major Fuber.

44. " fuliginosus strick.
45. Puffinus anglorum Temm.

46. Stercorarius pomarinus Temm.

47. “ parasiticus Temm.

48. "، cepphus Ross.

49. I arus leucopterus $F a b e r$.*

50. " marinus Linn.

51. " "Smithsonianus Coues.

52. " delawarensis $\mathrm{O} \cdot d$.

53. Chrococephalus atricilla Lawr.

54. " " Philadelphia Lawr.

55. Rissa tridactyla Bonap.

56. Sterna macroura Naum.

57. Colymbus septentrionalis Linn.

58. Podiceps Holbollii Reinh.

59. “ cristatus Lath.

60. " cornutus Lath.

61. Utamania torda Leach.

62. Mormon arctica Illiger.

63. Uria grylle Latham.

64. Cataractes troile Bryant.

65. " " ringvia Bry.

66. “ lomvia Bry.*

67. Mergulus alle Vieill.

\section{Spring and Autumn Visitants.}

Of some species properly regarded as spring and autumn visitants, a few individuals remain through the winter, in sheltered situations, or through the summer, now and then breeding. Those of which some remain in winter are marked with this*; those in summer, with this $\dagger$. There may be a few other species of this character not thus marked, as Empidonax faviventris, Vireo solitarius, \&c., that should be.

1. Hypotryorchis columbarius $\mathbf{G r}$.

2. Pandion carolinensis Bon.

3. Empidonax flaviventris Baird.

4. Turdus Pallassi Cub.†

5. $\{$ Turdus Swainsonii $C a b$.

5. " alicia Baird.

6. Regulus calendula Licht.

7. Anthus ludovicianus Licht.

8. Geothlypis Philadelphia $B d$.

9. Oporornis ngilis Baird

10. Helmitherus Swainsonii Bon.

11. Helminthophaga pinus Baird.

12. " " chrysoptera $B d$.

13. " " celata Baird.

14. " peregrina Baird.

15. Dendroica coronata Gray.

16. " castanea Baird.

17. 6 striata $B d$.

18. "6 maculosa $B d$.

19 a tigrina $B d$.
20. Dendroica palmarum $B d$.

21. Wilsonia pusilla Bon.

22. Euthlypis canadensis $\mathrm{Cab} . \dagger$

23. Vireo solitarius Vieill.

24. Zonotrichia leucophrys Swain.

25. "6 albicollis Bon.

26. Junco hyemalis Sclat.*十

27. Helospiza Lincolnii Baird.

28. Passerella illiaca $S w$.

29. Scolecophagus ferrugineus $S w$.

30. Charadrius virginicus Borck.

31. Egialeus semipalmatus Reich.

32. Strepsilas interpres Illig.

33. Phalaropus Wilsonii $C a b$.

34. " hyperboreus Temn.

35. "6 fulicarius Bonap.

36. Macroramphus griseus Leach.

37. Tringa canutus Linn.

38. Ancylochilus subarquata Kaup.

39. Pelidna americana Coues. 
40. Actodromas maculata Cass.

41. “ pusillus Coues.

42. " Bonapartii Cass.

43. Calidris arenaria Illig.

44. Ereunetes pusilla Cass.

45. Micropalama himantopus $B d$.

46. Gambetta melanoleuca Bon.

47. “ flavipes Bon.

48. Rhyacophilus solitarius Bon.

49. Tringites rufescens $C a b$.

50. Limosa tedoa Ord.

51. " hudsonica Swain.

52. Numenius longirostris Wils.

53. " " hudsonicus Lath.

54. "s borealis Lath.

55. Porzana noveboracencis-?

56. Bernicla canadensis Boie.

57. “ Hutchinsii Bon.
58. Bernicla brenta Sleph.

59. Anas boschas Linn.

60. Nettion carolinensis $B d$.

61. Querquedula discors Steph.

62. Spatula clypeata Boie.

63. Chaulelasmus streperus $\boldsymbol{G r}$.

64. Mareca americanca Steph.

65. Fulix marila Baird.

66. " affinis $B d$.

67. " collaris $B d$.

68. Aythya americana Bonap

69. "* vallisneria Bon.

70. Harelda glacialis Leach.

71. Procellaria glacialis Linn.

72. Sterna frenata Gambel.

73. Hydrochelidon fissipes Gray

74. Podilymbus podiceps Lawr.

\section{Summer Visitants.}

Of some species of which the greater part are merely summer visitants a few individuals remain in winter, but not enough to entitle the species to be considered resident, and are marked thus *; those of which the greater part pass north to breed, thus $\dagger$; those of which but few reach us in summer from the south, thus $\ddagger$.

1. Accipiter Cooperii Bon.

2. “ fuscus Bon.

3. Buteo lineatus Jard.*

4. " pennsylvanicus Bon.

5. Coccygus americanus Bon.

$6 . \quad$ “ erythrophthalmus $B p$.

7. Sphyropicus varius Baird.

8. Melanerpes erythrocephalus $\mathbf{S} w$.

9. Colaptes auratus Swarn.

10. Trochilus colubris Linn.

11. Chætura pelasgia Steph.

12. Antrostomus vociferus Bon.

13. Chordeiles popetue Baird.

14. Ceryle alcyon Boie.*

12. Tyrannus carolinensis $B d$.

16. Myiarchus crinitus Cab.‡

17. Sayornis fuscus Baird.

18. Contopus borealis Baird.

19. “ virens $C a b$.

20. Empidonax Traillii $B d$.

21. "6 minimus $B d$.

$22 . \quad$ " acadicus $B d$.

23. Turdus mustelinus Gmel.

24. " fuscescens Steph.

25. “ migratorius Linn.*

26. Sialia sialis Baird.

27. Mniotilta varia Vieill. $\dagger$ -
28. Parula americana Bon.

29. Geotlilypis trichas $C a b$.

30. Icteria viridis Bon. $\neq$

31. Helmitherus vermivorus Bon.

32. Helminthophaga ruficapilla $B d$.

33. Siurus aurocapillus $\boldsymbol{S} w$.

34. " noveboracensis Nutt.

35. Dendroica virens $B d$.

36. " canadensis Bd.t

37.

38.

39.

40.

41.

42.

43.

44.

45.

46.

47.

48.

49. Progne purpurea Boie.

50. Ampelis cedrorum Baird.

51. Vireo olivaceus Vieill.

52. " gilvus Bonap.

53. " noveboracensis Bon.

54. " flavifrons Tieill.

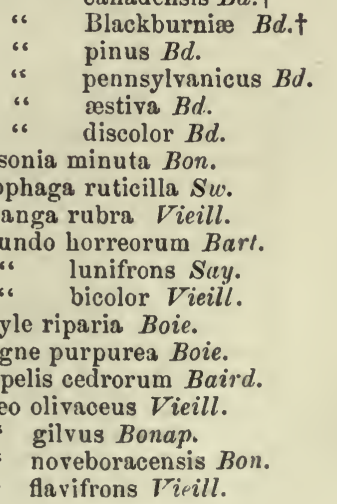


55. Mimus polyglottus Boie.

56. Galeoscoptes carolinensis $\mathrm{Cab}$.

57. Harporhyncus rufus $\mathrm{Cab}$.

58. Cistothorus palustris $C a b$.

59. “ stellaris $\mathrm{Cab}$.

60. Troglodytes ædon Vieill.

61. Carpodacus purpureus $G r . *+$

62. Passerculus savanna Bon.

63. Poœcetes gramineus $B d$.

64. Coturniculus passerinus Bon.

65. " Henslowii Bon.

66. Ammodromus maritimus $S w$.

$67 . \quad$ " caudacutus $S w$.

68. Spizella pusilla Bon.

69 "socialis Bon.

70. Melospiza melodia Baird.

71. Helospiza palustris $B d$.

72. Euspiza americana Bon.

73. Guiraca ludovicana $S w$.

74. Cyanospiza cyanea Baird.

75. Pipilo erythophthalmus Vieill.

76. Dolichonyx oryzivorus $S w$.

77. Molothrus pecoris $\mathbf{S} w$.

78. Agelæus phœniceus Vieill.

79. Sturnella magna Swain.*

80. Icterus spurius Bon.‡
81. Icterus Baltimore Daud.

82. Quiscalus versicolor Vieill.

83. Ectopistes migratorius $S w$.

84. Zenædura carolinensis Bon.

85. Ardea herodias Linn.

86. Ardetta exilis Gray.

87. Botaurns lentiginosus Steph.

88. Butorides virescens Bon.

89. Nyctiardea Gardenii $B d$.

90. Oxyechus vociferus Reich.

91. Ochthodromus Wilsonius Reich.‡

92. Agialeus melodus $\mathrm{Cab}$.

93. Squartarola belvetica Cur.

94. Hæmatopus palliatus Temm.

95. Philohela minor Gray.

96. Gallinago Wilsonii Bon.

97. Symphemia semipalmata Hartl.

98. Tringoides macularius Gray.

99. Bartramia lacticauda Less.

100. Rallus rirginianus Linn.

101. Purzana carolina Vieill.

102. Aix sponsa Boie.

103. Sterna hirundo Linn.

104. " paradisea Brunn.

105. " a aranea Wils.

106. " fuliginosa Gm.

\section{Accidental and Irregular Visitors.}

The following species are known in this State merely as rare chance visitors, a few only excepted, from the common habitat of their respective species. The others are very irregular in their visits. There are many other species so extremely rare that there are but few known instances of their capture in the State ; but from what is known of their distribution we are not to regard them in the light of chance visitors.

1. Cathartes atratus Lesson.
2. " aura Ill.
3. Falco candicans Gmelin.
4. Syrniunr cinereum Aud.
5. Nyctale Richardsonii Bon.
6. Picoides arcticus Gray.
7. Centurus carolinus Bon.
8. Icteria viridis Bon.
9. Pyranga rativa Vieill.
10. Ampelis garrulus Linn.
11. Mimus polyglottus Boie.
12. Parus hudsonicus Forster.
13. Curvirostra leucoptera Wils.
14. Agiothus linaria Cab.
15. Centrophanes lapponicus Kaup.
16. Chondestes grammaca Bon.
17. Helospiza Lincolnii Baird.
18. Euspiza americana Bon.

1. Cathartes atratus Lesson.

3. Falco candicans Gmelin.

4. Syrniunr cinereum $\mathcal{A} u d$.

5. Nyctale Richardsonii Bon

6. Picoides arcticus Gray.

7. Centurus carolinus Bon.

9. Pyranga æstiva Vieill.

10. Ampelis garrulus Linn.

11. Mimus polyglottus Boie.

12. Parus hudsonicus Forster.

13. Curvirostra leucoptera Wils.

15. Centrophanes lapponicus Kaup.

16. Chondestes grammaca Bon.

18. Fuspiza americana Bon.
19. Cardinalis virginianus Bon.

20. Quiscalus major Vieill.

21. Corvus carnivorus Bartram.

22. " ossifragus Wils.

23. Tetrao canadensis Linn.

24. Garzetta candidissima Bon.

25. Herodias egretta Gray.

26. Florida cærulea Baird.

27. Ibis Ordii Bon.

28. Ochthodromus Wilsonius Reich.

29. Rallus crepitans $\boldsymbol{G} m$.

30. Galinula galeata Bon.

31. “ martinica Lath.

32. Bernicla leucopsis Linn.

33. Nettion crecca Kaup.

34. Mareca penelope Bon.

35. Sterna paradisea Brunn.

36. $\therefore$ fuliginosa $G m$. 


\section{Summary.}

Number of species found at Springfield . . . . . . 195

os of o 6 in the State . . . . . 296

" "6 " that breed in the State . . . . 131

" " resident species . . . . . . . . 28

Winter visitants . . . . . . . . . 67

Spring and Autumn visitants . . . . . . 75

Summer visitants . . . . . . . . . . 106

Chance visitors . . . . . . . . . 35

Springficld, April, 1864.

Supplemental Notes. While the preceding paper has been passing through the press the following facts have been ascertained:

A specimen of the Snowy Owl (Nyctea nivea Gray) was taken in Springfield, the present year, about May 20th. Another instance of its capture here late in May has occurred within a few years. It has been found here repeatedly in November, and consequently spends at least half the year here.

A specimen of the Yellow-billed Cuckoo (Coccygus americanus Bonap.) was killed here in May this year, by Mr. B. Hosford, who informs me that he obtained another specimen here several years sincê. The capture of only three specimens of this species at Springfield has as yet come to my knowledge.

That the Hermit Thrush (Turdus Pallasi Cab.) does occasionally breed at Springfield I am now convinced, having seen a specimen shot here in July, but the instances appear to be extremely rare

In the preceding list of the Birds of Springfield, the Prairie Warbler (Dendroica discolor Baird) is mentioned as rare, and as not breeding at Springfield. I find it not uncommon in sandy fields, growing up thinly to pitch pines, the present summer, where it is breeding quite plentifully. It was not uncommon in June to hear several males singing at a time.

ESSEX INST. PROCEED, VOL. JV. M. 
A pair of Yellow-breasted Chats (Icteria viridis Bonap.) are breeding here the present season. Noticed another pair in Ludlow, Mass., about June $3 d$, which were probably also breeding.. Have seen a specimen taken in Berkshire county, in the breeding season. Only straggling pairs of this species, however, reach Massachusetts.

The following species of Hawks, though extremely rare in winter, should probably be properly included in the above list of "Resident Species :" Hypotriorchis columbarius Gr., Accipiter Cooperii Bon., A. fuscus Bon., Buteo lineatus Jard., and B. pennsylvanicus Bon.

July, 1864.

K. Notes on the Habits of some species of Humble Bees. By F. W. Putnam.

(Communicated October 22, 1863.)

During the summer of 1862 , while in Warwick, Mass., my attention was called to the Humble Bees by finding three nests of Bombus fervidus Fabr. and B. vagans Smith. These nests were formed of the deserted nests of mice, one under a barn in an old stump of a tree, the other two under piles of stones in a field. One of the nests of $B$. fervidus I kept in a box for some time, and watched the actions of the bees, but as I then neglected to make full notes, and as my first observations were confirmed by later ones, 1 allude to them here only to introduce an incident which has relation to the duration of life of the various kinds which always compose the communities of the Humble Bees. Upon leaving Warwick I left my valise, in which was a nest of bees, at the depot. Two months afterwards, in November, it was brought to me, when upon examining the nest several large queen bees were found in a lively condition, while the males, small females and workers were all dead. When the valise was left at the depot there was but one queen in the nest. This incident proves that the queens are not only late in leaving the cells, but that they are capable of enduring cold which is 


\section{AMERICAN NATURALIST.}

Vol. III. - DECEMBER, 1869. - No. 10.

ancoronos

\section{NOTES ON SOME OF THE RARER BIRDS OF MASSACHUSETTS.*}

BY J. A. ALLEN.

THe Natural History of any portion of country cannot, of course, be too fully known; and the few ornithological notes at this time presented I feel sure will be acceptable to those who are interested in the study of the New England birds. While a large portion of the facts now communicated are of my own observing I am greatly indebted to the kindness of other persons for many of the interesting notes that, during the last five years, have been accumulating in my note-book. As the authorities upon which the observations not my own in the following pages are communicated are always indicated, I have here but to return thanks to my numerous ornithological correspondents and friend's who have so generously favored me from time to time with their valuable contributions. Only by knowing thoroughly the fauna of a locality can the subsequent changes in it, induced by its becoming more densely settled, or by

\footnotetext{
*A supplement to a Catalogue of the Birds of Massachusetts, published five years since by the writer in the fourth volume of the Proceedings of the Essex Institute.
}

Entered according to Act of Congress, in the year 1869, by the PEABODY ACADEMY OF SciexcE, in the Clerk's Office of the District Court of the District of Massachusette.

ANER. NATURALIST, VOL. III. 
other causes, be traced. As is well known, the mammalian and bird faunæ of all the older settled parts of the United States are vastly different from what they were two hundred years ago. These changes consist mainly in the great decrease in numbers of the representatives of all the larger species, not a few of which are already extirpated where they were formerly common; a few of the smaller species of both classes have doubtless increased in numbers. Two causes operate unfavorably upon the larger ones; the disforesting of the country and the sporting propensities of the people, everything large enough to be shot, whether useful or otherwise, being considered as legitimate game. The former destroys the natural haunts of many species, while the latter destroys and drives away others that would otherwise remain. Many of the water-fowl that are now only transient visitors, as the Canada Goose, the several species of Merganser, Teals, Black Duck and Mallard, undoubtedly once bred in this State, as did also the Wild Turkey and the Prairie Hen. Several of the Gulls and probably some of the Tringce have been driven, like the Ducks and Geese, to seek more northern breeding grounds. In comparatively recent times, geologically speaking, probably other causes, as climatic, have been operating to effect a gradual northward migration, in certain species at least. These changes are of great interest, not only generally, but in a scientific point of view, and we shall be able to trace them and their causes only by comparing, from time to time, exhaustive faunal records of the same localities.

In a district so little diversified as that portion of Massachusetts lying east of the Connecticut River, it is perhaps a little unexpected that marked discrepancies should occur in the observations made at adjoining localities by equally competent naturalists, in respect to the relative abundance of certain species. As every experienced observer must have noticed that the birds of passage, as many of the Warblers especially, vary greatly in numbers in different 
years, and in the time occupied by them in passing a given locality, it is less surprising that at different points they should vary in abundance the same year. Among the birds that regularly breed in the district in question, there are some that are not equally common at all points. The Savannah Sparrow .(Passerculus savanna), for instance, that along the coast and on the islands is one of the most common species of its family during the summer, is almost unknown at this season in the interior of the state, although a species that at different seasons of the year is found throughout nearly the whole continent. The Swanip Sparrow (Melospiza palustris) is likewise locally restricted, for while a common summer bird in many of the larger swamps in the eastern part of the state, as the Fresh Pond marshes in Cambridge, it has thus far escaped the detection of very expert observers in the interior and western part. The Yellow-winged Sparrow (Coturniculus passerinus) is likewise partial to peculiar localities, preferring apparently sandy plains and dry open pastures; while it is one of the most numerous summer sparrows about Springfield, on Cape Cod and at Nantucket, it is generally much more rarely observed in the eastern counties of the state, where at some localities it is deemed rare. The same remarks apply to other species, as the Solitary and White-eyed Vireos (Lanivireo solitarius and Vireo Novceboracensis), etc. The Prairie Warbler (Dendroeca discolor) is much more at home in old pastures partially grown up to barberries and cedars than elsewhere. The Song Sparrow (Melospiza melodia), generally so numerous everywhere, I found last year was one of the rarest sparrows on the islands and extreme coast border, where its relative, the Savannah, was so common.

Birds, as probably other animals, are not quite so invariable in their habits as has been commonly supposed, nor in the precise character of their notes and songs, or the situation and materials of which they compose their nests. Hence one should not rashly question the accounts given by usually 
reliable authorities, because in particular instances they do not accord with their own observations. Neither should differences in habits, in song, etc., be taken as infallible evidence of a difference of species. It is well known that in Massachusetts the Brown Thrush (Harporhynchus rufus) is not uniform in the location of its nest, as about Springfield it almost invariably builds on the ground (in the many scores of nests that I have seen there I have met with but a single exception), while in other localities it as invariably places its nest a little above the ground in bushes. At Evanston, Ill., I once found one in an oak higher than I could reach; the locality, however, was swampy. How universally the Chipping Sparrow (Spizella socialis) breeds in trees, and generally at an elevation of several feet, is well known, but several authentic instances of this bird's nesting on the ground have come to my knowledge, one of which I myself discovered. Variations of this character in other species are of occasional occurrence, examples of which have doubtless been met with by every experienced collector.

The materials which birds select in the construction of their nests are well known to vary in different localities; the greater care exhibited by some species to secure a soft warm lining at the north that are much less precautious in this respect at the south, is already a recorded fict. Aside from this, the abundance of certain available materials occurring at only particular localities gives a marked character to the nests there built, which serves to distinguish them from those from other points. Some of the Thrushes, for instance, make use of a peculiar kind of moss at some localities that elsewhere, from its absence, are compelled to substitute for it fine grass or dry leaves. At Ipswich, on Cape Cod, and perhaps generally in the immediate vicinity of the sea, the Purple Grackles (Quiscalus versicolor) and Red-winged Blackbirds (Agelceus phoeniceus), and in fact numerous other species, in building their nests often use little else than dry eel-grass or "sea-wrack," which results in 
nest-structures widely different in appearance from those of their relatives residing in the interior. Every egg-collector is aware of the wide variations eggs of the same set may present, not only in the markings and in the tint of the ground color, but in size and form, and especially how wide these differences sometimes are in eggs of different birds of the same species. Also how different the behavior of the bird is when its nest is approached, in some cases the parents appearing almost utterly regardless of their own safety in their anxiety for their eggs or helpless young, while other parents of the same species quietly witness the robbing of their nest at a safe distance, and evince no extraordinary emotion. Those who have witnessed this, and have also watched the behavior of birds when undisturbed in their quiet retreats, will grant, I think, the same diversity of disposition and temperament to obtain among birds that is seen in man himself.

In respect to the songs of birds, who that has attentively listened to the singing of different Robins, Wood Thrushes or Purple Finches, has not detected great differences in the vocal powers of rival songsters of the same species? Different individuals of some species, especially among the Warblers, sing so differently that the expert field ornithologist is often puzzled to recognize them; especially is this so in the Black and White Creeper (Mniotilta varia) and the Black-throated Green Warbler (Dendroeca virens). But the strangest example of this sort I have noticed I think was the case of an Oriole (Icterus Baltimore) that I heard at Ipswich last season. So different were its notes from the common notes of the Baltimore that I failed entirely to refer them to that bird till I saw its author. So much, however, did it resemble a part of the song of the Western Meadow Lark (Sturnella magna; S. neglecta Aud.) that it at once not only recalled that bird, but the wild, grassy, gently undulating primitive prairie landscape where I had heard it, and with which the loud, clear, rich, mellow tones of this beau- 
tiful songster so admirably harmonize. This bird I repeatedly recognized from the peculiarity of its notes during my several days stay at this locality. Aside from such unusual variations as this, which we may consider as accidental, birds of unquestionably the same species, as the Crow, the Blue Jay, the Towhe and others, at remote localites, as New England, Florida, Iowa, etc., often possess either general differences in their notes and song, easily recognizable, or certain notes at one of these localities never heard at the others, or an absence of some that are elsewhere familiar. This is perhaps not a strange fact, since it is now so well known that birds of the same species present certain well marked variations in size according to the latitude and elevation above the sea of the locality at which they were born, and that they vary considerably, though doubtless within a certain range, in many structural points at one and the same locality. In other words, since it is known that all the different individuals of a species are not exactly alike, as though all were cast in the same die, as some naturalists appear to have believed.

Certain irregularities in the breeding range of birds have also come to light. It is perhaps not remarkable that a pair of birds of species that regularly breed in northern New England should now and then pass the summer and rear their young in the southern part, as has been the case in certain known instances in the Snow Bird (Junco hyemalis), the Pine Finch (Chrysomitris pinus), and the White-throated Sparrow (Zonotrichia albicollis); but it is otherwise with the Snow Bunting (Plectroplianes nivalis), which rarely breeds south of Labrador, of which there is a single well authenticated instance of its breeding near Springfield. The casual visits of northern birds in winter, which we may suppose sometimes results from their being driven south by want of food or the severity of the season, are also less remarkable, it appears to me, than the occurrence here of southern species, as of the two Egrets, the Little Blue Heron 
(Florida ccerulea) the Gallinules and other aquatic species, which never, so far as known (with one exception perhaps), breed so far north. In the latter case they are generally young birds that reach us towards fall in their chance wanderings.

It may here be added that the cause of the migration of our birds still offers an interesting field for investigation. Observers are of late noting that in the case of some northern species that reach us only occasionally in their winter migrations, young birds only are at first seen, but if the migration continues the older birds appear at a later date. But sometimes young birds only are seen. This frequently happens in the case of the Pine Grosbeak (Pinicola eneucleator). The cause of their visits is not always, it is evident, severe weather; the last named species appearing sometimes in November, - weeks before severe cold sets in-while at other times it is not seen at all during some of our severest winters. The probable cause is more frequently, doubtless, a short supply of food, as last winter was remarkable in this state for its mildness and for the great number of northern birds that then visited us. It has repeatedly been observed that on their first arrival these unusual visitors are generally very lean, but that they soon fatten; an argument in favor of the theory that their migration was compelled by a scarcity of food.

Probably fewer birds are actually permanently resident at a given locality than is commonly supposed, for species seen the whole year at the same locality, as the Blue Jay, the Titmouse, the Brown Creeper, and the Hairy and Downy Woodpecker, etc., in Massachusetts, are represented, not by the same, but by different sets of individuals, those seen here in summer being not those seen in winter, the species migrating north and south, en masse, with the change of season. We are generally cognizant of a migration in a given species only when the great "bird wave" sweeps entirely past us either to the north or south. Some species, how- 
ever, seem actually fixed at all seasons, and are really essentially non-migratory, as the Spruce Partridge, and Quail (Ortyx Virginianus) are in New England. But only a small proportion, doubtless, of the so-called non-migratory birds at any given locality are really so.*

In connection with this topic of migration, the fact that some of the young or immature individuals of our marine birds, as the Herring Gull (Larus argentatus) and other species of that family, and several of the Tringæ, linger on our coast during summer, while the adult all retire northward, is one of some interest. Mature and strong birds only, in species that breed far to the north, evidently seek very high latitudes. Birds of the first year also appear to roam less widely than the older. In different species of the Gull family it is generally only the mature birds that in winter are seen far out at sea, though in the same latitudes the young may be numerous along the coast. All observant collectors are well aware of the fact that those birds that first reach us in the spring, of whatever species, are generally not only very appreciably larger, but brighter plumaged and in every way evidently more perfect birds than those that arrive later; and that in those species that go entirely to the north of us there is a much larger proportion of paler colored and immature birds, especially among the Sylvicolidce, or warblers, towards the close of the migrating season than earlier. Hence the presence here of a few individuals in summer of species that usually go farther north is not always sufficient evidence that the species breeds with us.

In reference to the notes which follow, they may be considered as forming a supplement, as already stated in a foot note, to a "Catalogue of the Birds of Massachusetts" published by me five years since. In the present paper seven species $\dagger$

* In respect to the proof whereon this proposition rests, see my remarks on this point in the Memoirs of the Boston Society of Natural History, Vol. i, Pt. iv, p. 488 (foot note).

† Strix pratincola, Surnia ulula, Turdus nævius, Seiurus Ludovicianus, Centronyx Bairdii, Micropalama himantopus, Pelecanus erythrorhynchus. fee $/ 2.6 .47$ fort trote 
are added to the list then given, four of which are entirely new to the fauna of the State, and the others have not before been fully established as occurring within it, though supposed to from their known general distribution. Two, the Barn Owl (Strix pratincola) and Varied Thrush (Turdus novius), have only been previously given in Dr. Coues' Addenda to his "List of the Birds of New England." *

The latter occurs only as a straggler from the far interior and western portions of the continent. Another now added, $24 \mathrm{f} .647$, fow the Baird's Finch (Centronyx Bairdii), discovered by Mr. C. J. Maynard at Ipswich (see notes beyond for farther particulars), is another similar example equally remarkable, it having been previously known only from near the mouth of the Yellowstone River. A few errors in that Catalogue are also now corrected, with the design of making that and the present paper a fair exposition of the ornithological fauna of the State, so far as it is at present known. Three species $\dagger$ there ineluded are now stricken out. Numerous unrecorded instances of the capture of rare speoimens within the State are also chronicled, as also the breeding of a few not before positively known to breed here. There are remarks also on a few species, for obvious reasons, that are not to be regarded as among the rarer species of the State.

The whole number of species of birdș now known to occur in Massachusetts is three hundred.

Gerfalcon. Falco sacer Forster. (F. candicans et Islandicus Auct.) A specimen in the speckled plumage was taken near Providence, R. I., by Mr. Newton Dexter, during the winter of 1864 and 1865. Its occurrence so far south appears to be wholly accidental.

The suspicion many authors have had that the $F$. candicans and $F$. Islandicus were but birds of the same species in different states of plumage, my own examination of speci-

* Proceedings of the Essex Institute, Vol. v, p. 312.

† Archibuteo Sancti-Johannis, Helminthophaga Swainsonii, Quiscalus major.

AMER. NATURALIST, VOL. III. 
mens of both, in the Museum of the Boston Society of Natural History and elsewhere, has led me to believe is actually the fact. Sabine, so long ago as 1819 , I think has fully shown this in his remarks on Falco Istandicus in his Memoir on the Birds of Greenland.* According to the late lamented Mr. Cassin, sacer is the specific name which has priority for this species. $\dagger$

DucK HawK. Falco peregrinus Linn. (Falco anatum Bon., and $F$. nigriceps Cass). I stated in my Catalogue, published five years since, that the eggs and the young of this species had been taken at different times from Mount Tom, and that the young had also been obtained from Talcott Mountain in Connecticut. A few months later I had the pleasure of giving a full account of the eyrie on Mount Tom, with a detailed description of the eggs, and some general remarks on the distribution of this interesting species in the breeding season. $\neq$ These eggs were the first eggs of the Duck Hawk known to naturalists to have been obtained in the United States, the previous most southern locality whence they had been taken being Labrador; but the species had previously been observed in the breeding season by Dr. S. S. Haldeman as far south as Harper's Ferry, Virginia. One or more pairs of these birds have been seen about Mounts Tom and Holyoke every season since the first discovery of the eggs at the former locality in 1864. Mr. C. W. Bennett, of Holyoke, their discoverer, has since carefully watched them, and his frequent laborious searches for their nest have been well rewarded. In 1866 he took a second set of eggs, three in number, from the eyrie previously occupied. In 1867 the male bird was killed late in April, and this apparently prevented their breeding there that year, as they probably otherwise would have done. At least no nest was that

*Transact. London Linn. Soc., Vol. xx, p. 528.

† See Dr. Coues' List of the Birds of New England, Proceedings of the Essex Institute, Vol. v, p. 254.

‡ See Proceedings Essex Institute, Vol. iv, p. 153. 
year discovered. In 1868 hawks of this species were seen about the mountains, and although they reared their young there, all effort to discover their nest was ineffectual. The present year (1869) they commenced to lay in the old nesting place, but as they were robbed when but one egg had been deposited, they deserted it and chose a site still more inaccessible. Here they were equally unfortunate, for during a visit to this mountain, in company with Mr. Bennett (April 28th), we had the great pleasure of discovering their second eyrie, and from which, with considerable difficulty, three freshly laid eggs were obtained. Not discouraged by this second misfortune, they nested again, this time depositing their eggs in the old eyrie from which all except the last set of eggs have been obtained. Again they were unfortunate, Mr. Bennett removing their second set of eggs, three in number, May 23d, at which time incubation had just commenced. The birds remained about the mountain all the summer, and from the anxiety they manifested in August it appears not improbable that they laid a third time, and at this late period had unfledged young.

The first set of eggrs and the female parent, collected April 19th, 1864, are in the Museum of Natural History at Springfield, as also a male killed subsequently at the same locality in April; the second set, collected in April, 1866, are in the cabinet of $\mathrm{Mr}$. E. A. Samuels; the third and fourth sets, collected April 28th and May 23d, 1869, are in that of Dr. William Wood, of East Windsor Hill, Conn. Although in each set the different eggs sometimes varied considerably from each other, neither of the three last present that remarkable range of variation exhibited by the first.* It is probable that some years more than one pair have nested on Mount Tom, but only one nest-site had been discovered before the present year. I learn from Dr. Wood that this bird is every year seen also about Talcott Mountain, and that it probably regularly breeds there. The young

* See Proceedings of the Essex Institute, Vol. iv, p. 157. 
obtained from it in $186 \%$ Dr. Wood kept till the following fall, when they were sent to Professor Baird, and died at the Smithsonian Institution the succeeding spring. Mr. G. A. Boardman informs me that the Duck Hawk in summer keeps about the islands in the Bay of Fundy, and "breeds upon the high cliffs all along this bay.*"

As stated by me elsewhere, $\uparrow$ the Duck Hawks repair to Mount Tom very early in the spring, and for a month or six weeks, as Mr. Bennett informs me, carefully watch and defend their eyrie. They often manifest even more alarm at this early period when it is approached than they do later when it contains eggs or young.

Sparrow HawK. Falco sparverius Linn. In reference to this species, Dr. Wood communicates the following interesting fact. "A few years since a pair of Sparrow Hawks attacked and killed a pair of doves and took possession of the dove cot and laid four eggs. Being too fumiliar with the farmer's chickens they were shot, and I had the good fortune to obtain two of the eggs."

Gosmawk. Astur atricapillus Bon. This species varies most remarkably in the number of its representatives seen in different years, and also in the same season at localities in Southern New England not far apart. Some wintersthe only season at which it is usually seen in Massachusetts - it is extremely rare, while the next it may be one of the most numerous species of its family. In years when it is generally common some of our most careful observers do not meet with it. Dr. Wood writes me, under date of October $22 \mathrm{~d}, 1868$, that with him "it has been a very rare winter visitor until the last winter, when they were more common than any of our rapacious birds. I mounted five specimens and sent away several for exchanges. I think twenty were shot within a radius of five miles. I have resided at East Windsor Hill twenty-one years, and have

* In epist., Sept. $19,1864$.

† Proceedings of the Essex Institute, Vol. iv. p. 155. 
known only three specimens taken here prior to 1867." At Springfield, less than twenty miles in a direct line north of East Windsor Hill, and at nearly the same elevation above the sea, I have known them to be quite common during several winters within the last ten years. Mr. J. G. Scott says it was common at Westfield in 1867, and not rare during the three or four winters immediately preceding. When numerous this species is very destructive to the Ruffed Grouse, which forms its principal food. In some localities they sometimes hunt them almost to extermination.

Mr. C. J. Maynard informs me that he is confident that this species sometimes breeds in Massachusetts. He says he once observed a pair at a locality in Weston until the latter part of May; after this time he had no opportunity of observing them, but he feels sure that they bred there. This is not improbable, since its usual breeding range embraces the greater part of northern New England, and probably the mountains of Western Massachusetts.

Dr. Wood mentions in his letters another interesting fact respecting this bird, which I think all careful observers are apt to notice, not only in this species but as a general fact; namely, that the birds in immature plumage are often larger than any specimens obtained in mature plumage. Dr. Wood observes, "the young are very unlike the adult both in size and markings ; the young is the largest until after moulting, when the wing and tail feathers never again acquire their former dimensions. The same difference is observable in the Bald Eagle between the young and the adult."* I have myself observed it in Ardea herodias and other Herons, in Thrushes, and in Larus argentatus, and other species of Laridce. This difference in size between the adult and the young has also been reported to me by Messis. Maynard and Bennett.

Red-shouldered Hawk. Buteo lineatus Jard. This species was placed in the list of "Summer Visitants" instead of 
among the "Resident Species," as it should have been, in my Catalogue. At Springfield, I have rarely observed it in winter; but I learn from Dr. Brewer, Mr. Maynard and others, that it is in some sections of the state a quite common species at that season.

California Hawk. Buteo Cooperii Cassin. A specimen of this species was shot in Fresh Pond woods, Cambridge, November 17, 1866, by Mr. William Brewster, of Cambridge, in whose collection it was detected a few months since by Mr. Maynard. It seems to be the first specimen yet reported from east of the Rocky Mountains. It is one of the most eharateristic of the Buteones of this continent, and there seems to be not the slightest reason to question its capture in Cambridge.

Rough-legged Hawk. Black Hawk. Archibuteo lagopus Gray. (A. lagopus et S'ancti-Johannis Auct.) Generally not uncommon in winter in the Connecticut Valley.

Dr. Wood is of the opinion that the Rough-legged Hawk and the Black Hawk are the same. "I have," he says, "all shades of color from the light to the black, and I am unable to find the dividing line; both have the same measurements, the same claws and bill, the same habits, come and leave at the same time, and hunt together. I have them almost black with the faint markings of the lighter bird, showing to my mind that the lighter markings become extinct as the black increases, or as the bird increases in age. Those who claim that they are distinct say that in some localities the Rough-legs are common and no Black Hawks are to be seen. This proves nothing. The young of the Red-throated Diver are very common in Long Island Sound, yet the adult is never seen there. So it is with the Crested Grebe; the young are found here in winter - never the adult." *

On another occasion, when writing on this point, Dr. Wood expressed his views still more strongly, as follows: "The Rough-legged Falcon and Black Hawk are the same. I have 
taken and examined, I presume, forty specimens. They are the same bird, but not of the same age. The black is the adult. . . . The differences in markings between them are not as great as in many birds, as, for example, in the Bald Eagle, the Golden Eye, Sheldrake, etc. I have taken them from those with the lightest markings to jet black, with all the intermediate varieties in color. So gradually do they become more and more black till jet black is reached, that I will defy any one to draw the separating line. It would be as difficult as to tell when the "pig becomes a hog." *

The late Mr. Lucius Clarke, of Northampton, I have been informed, had a similar series, and that from an examination of a large number of specimens he had arrived at the same conclusion. I have not yet had an opportunity of comparing a very large number, but from a study of those I have seen, and of the accounts given by authors, I believe the view taken by Dr. Wood and Mr. Clark to be the correct one.

\section{TROUT FISHING IN THE YOSEMITE VALLEY. BY HON. J. D. CATON.}

BY far the hardest day's work the tourist has in "doing" the wonderful valley is the visit to the Vernal and the Nevada falls, where the Merced River makes a clear leap of three hundred feet over the first, and seven hundred feet over the second. Our guide, Mr. Cunningham, assured me that not a fish of any kind is found in the river, or any of its tributaries above the first or lower fall. Below these falls several varieties occur, the most interesting and the most abundant of which is the Speckled Trout (Salmo iridea Gib.). It differs materially from its cousin, the Speckled Trout of the Enstern States (Salmo fontinalis), especially in habit and 
coloring, and is more sluggish in movement and less voracious in appetite. Its spots are all black, less regular in size, form and arrangement, and it has a coppery stripe running along the lower part of either side. It was the unanimous verdict of our party that its flesh is inferior to that of the eastern brook trout, though it was highly relished by all. The waters of the river are almost as transparent as the atmosphere, and are as cold as it is safe to bathe in. The trout were so abundant that usually several were in view to the observer standing on the river bank, but so shy that one would rarely remain within forty feet.* The Indians daily brought in large strings taken with the hook, which they sold to Mr. Hutchings, our landlord; but it was said, that with one exception, no white man had ever taken one. The bait always used by the natives is the angle-worm, which Mr. Hutchings assured me was found abundant in the valley by the first white visitors. I may pause here to say that this statement interested me much from the fact that none of these worms were ever found on Lake Superior till they were planted there; ten years ago those who used them for bait were obliged to take them along. I planted the first at Eagle River, seven years since, with worms taken from Ottawa, Illinois, and they have flourished finely since.

After nine hours of travel on a very hot day, we returned from viewing the falls to the botel. While the rest of the party sought rest on beds in their rooms, or on robes or blankets under the oaks, I determined to try my hand with the trout. I overhauled my satchel and found a few flies and some naked hooks, and a very indifferent line. Mine host loaned me a Chinese rod, which answered well enough. I first essayed with artificial flies, from behind a bunch of willows, by which I was entirely concealed. They simply laughed at all my efforts at deception. They seemed as indifferent to any fly which I had as they would

\footnotetext{
* They were generally observed moving slowly about from six to twelve inches below the surface. The current is very strong.
} 
here it is brought in contact with the sunlight and air, and certain chemical changes take place in its composition. Dornwwards, through another set of ducts, it is carried just inside the bark, and here through its instrumentality, woody fibre is deposited, one fibre upon the other externally, and thus the twig grows by outside growth, becoming thicker and thicker each year. This addition of substance goes on during the spring and autumn months, the plant doing very much the same as human beings, that is to say, resting during the hot season. But when winter comes its growth is arrested entirely, and like the hibernating animals the tree sleeps. Now in animals the blood is carried by a set of vessels, known as arteries, to the lungs, where it comes in contact with the air inhaled, and has its composition so changed that it can build up new tissues. The same thing, essentially, we see, takes place in the tree, the leaves representing the lungs, or oxygenating organs. Now as the tree sleeps during the winter months here is an arrest of growth, and therefore when we examine such a cross-section of a piece of wood as we have given, we find a number-less or greater, according to the number of winters it has existedof these rings of arrested growth, and by counting them we can arrive at the age of such a stick of wood. So we see how the microscope assists in acquiring such a knowledge; and of course we shall find similar structure in all outside growers or Exogens. With inside growers the case is very different; for here the new matter is not deposited externally in regular rings; and, in fact we can, from a consideration of the fucts we have related, readily understand why the Endogens are mostly confined to such portions of the globe where there are no cold months to arrest the growth. However, even in such climates, Exogens grow and rest also during a part of the year. We have given the two sections represented to show the very marked difference in these two modes of growth as illustrated by microscopic sections, and those who desire to verify our illustrations can readily do so 
by cutting a slice of some green stem, when the sap is in the wood and it is therefore the more readily cut, and also taking a slice of some Endogen, the garden asparagus being an excellent plant for that purpose, and after placing them on a glass "slide" and moistening them with water, covering them with a piece of thin "covering glass," and then examining them with a microscope; even an ordinary pocket lens will often show these points of structure very well. Thus will the student of nature find instruction and amusement, knowledge and pastime, even in a shaving of wood cast off from a carpenter's jack-plane.

EXPLANATION OF PLATE 10.

Fig. 1. Section of oak wood cut transversely across the grain. Fig. 2. Transverse section of sugar cane.

Both magnified 25 diameters.

\title{
NOTES ON SOME OF THE RARER BIRDS OF MASSACHUSETTS.
}

\author{
BY J. A. ALLEN.
}

(Continued from page 519.)

Golden Eagle. Aquila chrysaëtos Limn. (A. Canadensis auct.) A specimen was killed near Munson in November, 1864, and another near Deerfield, December 14th, 1865. The latter, a female, is said to have weighed thirteen and a half pounds, and to have measured seven feet and six inches in alar extent. It is now in the Springfield Museum of Natural History. Mr. J. G. Scott informs me that two specimens were captured near Westfield three years ago, one of which is in his cabinet.* 
Osprey. Fish Hawk. Pandion haliaëtus Sav.* ( $P$. Carolinensis Bonap.) It seems at first a little strange that this noble bird should not be found breeding any where on the Massachusetts coast, but when we recall the peculiar situations usually chosen by it for its eyrie we cease to be surprised. At present there are here no heavy forests near the sea, with lofty dead trees spreading their broad whitened arms to receive its bulky and conspicuous nest. All who are acquainted with this bird's breeding habits must have been struck with its marked predilection for such nesting sites. While it breeds abundantly on the New Jersey coast, on portions of Long Island, on the coast of Maine and about the large lakes in the interior, it is now only seen in this state, so far as I can learn, during its migrations. It undoubtedly nested here before the thorough disforesting of the seacoast; a former nesting site near Ipswich being still remembered by some of the older residents there. The present puny second forest-growth affords it no suitable breeding places, and this is no doubt the reason of its being now but a transient visitor here.

Hawk Ows. Surnia ulula Bon. Mr. A. L. Babcock of Sherborn, has a specimen which he took a few years since at Natick. Dr. Brewer informs me he once obtained it near Roxbury. Mr. Scott writes that five specimens were taken at Westfield, near the village, in the autumn of 1867. In my Catalogue this species, though mentioned incidentally. as probably occurring occasionally along the Green Mountain ranges in the western part of the state, was not reckoned as a Massachusetts bird. Dr. Emmons salys it has been observed in that section in autumn, $\dagger$ and from what I now know of its distribution I doubt not it is a somewhat regular winter visitor there.

\footnotetext{
*In the Museum of Comparative Zoölogy are numerous specimens of this bird, from Brazil, Florida, and New England, the North, and from Europe. They differ a good deal, but some of those that differ most are from the same locality. I cannot see wherein the European differ essentially from the American. Some of these are more like the Ainerican than some of the American are like each other.
}

$\dagger$ Hitchcock's Geological Report for 1835 .

A.MEr. NatUraLIST, vol. III. 
Great Gray Owl. Syrnium cinereum Bon. I mentioned the capture of several specimens in this state in my Catalogue. Dr. Brewer has since informed me that about 1839 he obtained two for Mr. Audubon that were shot near Boston, - a fact which does not appear to have been previously recorded. There is also a specimen in the Museum of the Peabody Academy, taken in Salem, November 10th, 1866, by Mr. E. S. Waters.

Great Horned Owl. Bubo Virginianus Bon. There are three specimens of this species in the Museum of Comparative Zoölogy, all from Eastern Massachusetts, that represent Mr. Cassin's three varieties Bubo Virginianus Atlanticus, B. Virginianus Pacificus, and B. Virginianus Magellanicus. The first of these he supposed to be restricted to the Atlantic slope of North America, the second to the Pacific slope, and the third to the extreme southern parts of this continent and to South America. Mr. Cassin remarks, "this fine species is either subject to considerable variation in the color of its plumage, or there are several species, some of which have been named by naturalists, as cited above, in our synonymes." * The first of these alternatives it seems to me is the true state of the case.

BARN OWL. Strix pratincola Bon. As already stated by me in the "Addenda" to Dr. Coues" "List of the Birds of New England," the first specimen of this species known to have been captured in this state was taken near Springfield, in May, 1868. Dr. Wood informs me that he has a specimen in his cabinet that was shot "at Sachem's Head [Ct., ], October 28th, 1865." The capture of another at Stratford, Connecticut, is recorded by Mr. Linsley. $\dagger$ These three are all thus far known to me to have been taken in New England.

Yellow-Billed Cuckoo. Coccygus Americanus Bon. No other of our birds seems to be so variable in numbers in

\footnotetext{
* Report on N. American Birds, p. 50.

† See "Catalogue of the Birds of Connecticnt," by Rev. J. H. Linsley, Am. Journ. Science and Arts, Vol. xliv (1813), p. 253.
} 
different years as this. In my Catalogue it is mentioned as "extremely rare" at Springfield, but as occurring frequently in the eastern part of the state. Since then a number of specimens have been taken at Springfield, and others at Westfield, Chicopee and Holyoke. Dr. Wood says that it "has been very uncommon at East Windsor Hill, except in 1867, when it was as common as the Black-billed. I obtained," he adds, "three sets of eggs during that season; have seen none this year." * I think it was in 1867 that it was so unusually common at the other above-mentioned localities, but it was also taken at Springfield in 1866. Mr. Scott says he does not think it "extremely rare," as he has obtained four or five specimens without special effort. In the eastern part of the state I find it is not generally so numerous as I had supposed. It seems to be common here only at irregular intervals, when it sometimes appears to be as numerous as the Black-billed species, but sometimes it is scarcely observed for several seasons. Mr. Maynard says it was common about Newton during 1866, when the Black-billed was rare, but that it has not been so since that year, while the latter has been abundant. If the very large collections of birds from a considerable number of localities in New England in the Museum of Comparative Zoölogy can be taken as any index of their relative abundance in the Easter'n States, the Black-billed species may be considered as, on the average, a hundred fold more numerous than the other.

Yrelow-BFlaled Woodpecker. Sphyrapicus varius Baird. As observed by Dr. Coues, $\uparrow$ this bird may be common in summer at many localities in New England. But in this state, so far as I can learn, it is rare at all seasons in that portion east of the Connecticut, and generally seen only in the fall. Not so, however, to the westward and northward; but I doubt its being any more numerous in Rhode 
Island and Eastern Commecticut than it is in Eastern Massachusetts.

Pileated Woodpecker. "Log Cock." Hylotomus pileatus Baird. The capture here of a bird so nearly extirpated in most parts of Massachusetts as is this, is a fact of interest. Mr. J. G. Scott informs me that he has taken three specimens near Westfield. Dr. Wood wrote me in 1864 that one was killed about five years before at East Windsor Hill, and that he had also seen it about twenty miles to the westward of this locality.

Black-Backed Three-toed Woodpecker. Picoides arcticus Gray. Mr. Scott took two specimens, male and female, of this northern species at Westfield in 1867.

Banded Three-tond Woodpecker. Picoides hir'sutus Gray. I learn from Mr. George O. Welch, of Lynn, that he took a pair of these birds some years since not far from that town. Dr. Brewer also gave it in his additions to the "Catallogue of the birds of the state" given by Dr. Hitchcock, * but it has not usually been numbered among the birds of the state, and doubtless occur's only as an accidental winter visitor.

Yellow-Bellied Flycatcher. Empidonax faviventris Baird. As remarked by Dr. Coues in his "List of the Birds of New England," this species is probably less rare than the collectors usually suppose. It seems to prefer woods and thickets, and its close resemblance to $E$. minimus when a few yards distant tends to prevent its more frequent capture. I generally meet with quite a number each year in May, sometimes several in a single excursion. Mr. Maynard informs me that he took eight specimens in a few hours May 31st, the present year. It has been observed in the breeding season as far sonth as Washington, D. C., by Dr. Cones.

Varied Tirrush. Turdus noevius Gmelin. As already recorded in Dr. Coues "Addenda," this western species has at last been taken in Massachusetts, a specimen having been 
shot near Boston (at Ipswich) in December, 1864. This seems to be the first known instance, as the specimen mentioned by Prof. Baird as having been obtained here was killed in New Jersey.*

RoBıs. Turdus migratorius Limn. Generally this well known bird is not met with in Massachusetts in winter except at particular localities; it seems more frequently to occur at this season in the eastern part of the state than elsewhere. It is not seen every winter, but sometimes occurs in considerable abundance. In the severe winter of 1867-'68, they were seen in Cumbridge at intervals all winter; they were more numerous in January than in December, and were still more abundant in February, when they appeared in quite large flocks. They disappeared on the approach of warm weather, leaving for the north or for the interior before the arrival of their lorothers from the south, which this year first appeared about March 10th. It does not seem to be an unusual mildness of the season that causes them to linger, as they are as often seen during the severer winters as in the milder.

Hermir Thrush. Turdus Pallasi Cab. Although the southern limit of this species in the breeding season is nearly coincident with the southern boundary of the Canadian fauna, $\uparrow$ straggling pairs breed in various parts of Massachusetts. It has been taken at Springfield in June, $\ddagger$ and last year I saw young just able to fly at Hyannis, July $3 \mathrm{~d}$. Dr. Brewer informs me he found it breeding in Roxbury, in 1837. In the more elevated western districts of the state, as in the elevited and northern parts of New England generally, it breeds regularly and in large numbers.

Olive-Backed 'Thrush. Turdus Swainsonii Cab. As is well known, this is not a rare species in this state.

* See my "Catalogue," 1. c., p. 82.

†In respect to the boundaries of the Canadian and Alleghanian Fauna, see Prof. Verrill's remarks in the Proceedings of the Boston Society of Natural History (Vol. $x$, p. 260) and my own in the Memoirs of the Boston Society of Natural History, Vol. i, pt iv, p. 483.

† See "Addenda" to my "Catalogue," l. c.. p. 97. 
In my "Catalogue of Massachusetts Birds" I first advanced the opinion that the so-called T'urdus "Alicice" Baird, or Gray-cheeked Thrush, was but the paler form of this species. To this view other writers have taken exceptions. Prof. Baird, in his "Review of American Birds" (p. 21), summarily disposes of the matter by presuming that I had not seen what he called T. Alicioe. Dr. Coues, in his "List of the Birds of New England," in referring to my remarks on the subject, says they "illustrate very fully the well-known seasonal and other variations to which $T$. Swainsonii and $T$. fuscescens are subject," and adds that I appear to have been "autoptically unacquainted" with $T$. Alicice at the time of writing them. Since that time I have still firther considered the subject, and have had large series of authentic specimens of both $T$. Swainsonii and Alicice (mostly so labelled at the Smithsonian Institution) for comparison with Massachusetts specimens, and after five years of additional experience I am now more than ever convinced that the opinion there expressed is correct. Some years the Alicice type is quite common; again more rare. Generally, however, the majority of the specimens range between the forms considered as typical respectively of $T$. Swainsonii and $T$. Alicice.*.

Mocking Bird. Mimus polyglottus Boie. Several instances of the occurrence of this southern species in the vicinity of Springfield other than those previously recorded have come to my knowledge during the last five years, and also one of its occurrence in the easterin part of the state.

Connecticut Warbler. Oporornis agilis Baird. Concerning this species Mr. C. J. Maynard writes: "Perhaps not as rare as is generally supposed by collectors, especially in autumn. A specimen was shot by Mr. L. L. Thaxter in Newton Centre, September 16th, 1867. Another was taken by myself in September, 1868, in a thick swamp near Newton." $\dagger$

\footnotetext{
* For a fuller discussion of this subject, see my paper in the Memoirs of the Boston Society of Natural IIistory, Vol. i, part iv (1868), p, 507.

† MSS. notes, received June, 1869.
} 
Tennessee Warbler. Helminthophaga peregrina Cab. This species, generally rare here, appears to have been much less so this year than usually. Mr. Maynard took five at Newtonville during May 18th to the 23d, - the first, he says, he had seen. He informs me that his friend Mr. William Brewster procured at about the same time two near Mount Auburn. I have taken it repeatedly at Springfield, where I have always esteemed it rare; but Mr. Boardman says he finds it quite common near Calais, Maine.*

Goldex-Wixged Warbler. Helminthophaga chrysoptera baird. This beautiful warbler has been taken, so far as I can learn, but a few times in the western part of the state; it seems to be more common in the eastern, where it breeds. I saw it once in July at Springfield, and Mr. S. Jillson informed me some years since that it was quite frequent at Bolton, where it spends the summer and undoubtedly breeds. I am not aware that its nest has been found in the state prior to the present year, when it was discovered by Mr. C. J. Maynard, June 12th, near Newtonville. This gentleman says that for the last three years he has seen this Warbler in swampy thickets near Newton in June, and felt confident that it bred there. This year he observed a female so anxiously chirping from a. small elm that he felt sure she had a nest in the vicinity, and quietly watching her he soon saw her fly down into the weeds. Approaching the spot carefully he discovered her sitting on her nest. This he describes as situated on the ground, in a tract of coarse weeds and ferus near a swampy thicket, and but a few rods from a public highway. It was placed entirely above the surface of the ground, and the birds seemed to have made no special effort to conceal it. It was composed externally of dried oak leaves and the bark of the grape-vine, and rather roughly lined with fine griss and a few horse hairs. He says it is large for the size of the bird, and somewhat reminds one 
of the nest of the Maryland Yellow-throat. It is a little smaller at the top, where the internal diameter is less than two inches, while in the middle it is two and a quarter. The eggs were five in number, including a Cow Bunting's egg that these watchful parasites had introduced. The Warbler's eggs are thus described by Mr. Maynard:

"No. 1 is regular in form, thickly spotted and blotehed with dark brown at the larger end and sparsely at the smaller, on a white ground. Length, sixty-six one-hundredths of an inch; diameter, fifty-five onehundredths. No. 2 is like No. 1, only it is less thickly spotted. Length, sixty-six one hundredths; diameter, fifty-three. No. 3 is least spotted of the four, it being but sparsely so on the larger end and not at all on the smaller. Dimensions same as those of No.1. No. 4 is more elongated, and much the most spotted, the spots forming a broad band around the larger end, and are scattered over the remaining surface."

Mr. Maynard adds: "It is a curious fact that although I have seen and collected quite a number of males of this species, this is the first female that I have seen, although I have made diligent search for them."

Swainsox's Warbler. Helmithemus Swainsonii Bon. Although this species is recorded by both Audubon and Peabody as having been taken in Massachusetts, and on these authorities given in my Catalogue, there is some reason to doubt its having been captured here. Both notices doubtless refer to the same specimen, as well as to the same authority,-Dr. Brewer. But this gentleman informs me that the record is erroneous and the result of a misunderstanding; the specimen referred to he says was not this species at all. Dr. Brewer knows of no instance of its occurrence here, and it should doubtless be stricken from the list of Massachusetts birds. Dr. Coues says he has never seen it so far north as Washington, D. C. *

Worm-eating Warbler. Helmitherus vermivorus Bon. Mr. Peabody states, in his "Report on the Birds of Massachusetts," that the nest of this species had been found in Cambridge, which statement I repeated in my Catalogue. 
I have since been informed by Dr. Brewer that the nest referred to by Mr. Peabody as above "was, without doubt, a Nashville Warbler's. I do not think it occurs," he adds, "nearer than the Hudson River."* Prof. Verrill, however, in his list of the birds of Norway, Maine (p. 21), gives it as rare in the southern part of Maine. From its range being generally southern, its occurrence in New England can only be accidental.

Syall-headed Flycatcher. Wilsonia minuta Bon. This rather apocryphal species is given by Peabody as having been met with at Ipswich by Dr. Brewer, and in Berkshire County by Dr. Emmons (Rep. Orn. Mass. p. 297). Dr. Brewer writes me that in 1834 his eat caught a specimen of this species in Roxbury, which he sent to Audubon, though as Dr. Brewer observes, he (Audubon) makes no mention of it. Dr. Brewer renuarks: "This was the only one I ever knew or heard of. Ipswich I ignore." Compare with this Dr. Coues' remarks on this supposed species in his "List of the Birds of New England." $†$

Long-Billed Water Thrush. Seiurus Ludovicianus Bon. The first and only specimen thus far kuown to have been found in Massachusetts I captured April 28th, the present year, on Mount Tom. There is another in the Museum of Comparative Zoölogy, taken by Irving Frost, at Norway, Maine, in May, 1865. These two I believe are all the specimens known from New England, its actual occurrence in the Eastern States being now for the first time reported. $\neq$

Blackburnian Warbler. Dendroeca Blackburnice Baird. Mr. Bennett found the young of this species this year near Holyoke that were scarcely able to fly. This establishes its breeding in Massachusetts. This fact I had already inferred, as in $1863 \mathrm{I}$ shot it in Springfield, June 24th. Mr. J. G. Scott also shot it in Westfield, late in June, 1866. Some

* In epist., May 8, 1869.

† Proc. Essex Inst., Vol. v, p. 275.

$\ddagger$ See concerning this species Dr. Coues' List of New England Birds, 1. c. p. 271.

A.HER. NATURALIST, VOL. III. 
seasons they are extremely abundant at some localities, and commonly are not rare, except in particular situations. $\mathrm{Mr}$. Scott observes that for several weeks in May, in 1866, he could remain at a single place in the woods and shoot ten to twenty per hour.

Bay-breasted Warbler. Dendroea castanea Baird. This species I find is esteemed to be rare by most collector's in the eastern part of the state, but in the Connecticut valley it is generally more or less common and sometimes very abundant. I found it very numerous in 1866 in Springfield, and it seems to have been equally so the same year in Westfield. Mr. Scott writes, "I could easily have shot a bushel-basket full of them without very greatly changing my position." He says it was scarce in 1867, but not very rare in 1868 . In 1866 he obtained a partial albino. Mr. Maynard, however, considers it to be very rare about Newtonville. He has known only a few specimens taken there, as follows: June 19th, 1867, May 22d, 1868, and May 27th, 1869.

Prairie Warbler. Dendroeca discolor Baird. In particular situations a more or less common summer resident. In the eastern part of the state, especially in the breeding season, it is much more common than in the western. Old pastures partially grown up to cedars and barberry bushes seem to form its favorite resorts.

Cape May Warbler. Perissoglossa tigrina Baird. This species, like most of the warblers, varies greatly in abundance in different years and at different places. Generally it seems to be very properly regarded as rather rare. Specimens, however, are taken almost every year in different parts of the state, but generally they altogether number very few. Mr. Maynard tells me it has been found near Boston, by Dr. Bryant and others, to be some years quite common.

Summer Red Brrd. Pyranga, oestiva Vieill. Mr. A. L. Babcock, of Sherborn, has a specimen taken in Framingham 
some years since in May. This, I believe, forms the second authentic instance of its capture in this state. Two were taken in Lynn, April 21st, 1852, by Mr. S. Jillson.*

Northern Wax-iving. Ampelis garrulus Linn. The visits of this beautiful northern species so far south are very infrequent, and in only a few instances has it been recorded from this state. It has been taken, however, in Connecticut by Dr. Wood. I am also informed by Mr. S. Jillson, that eleven specimens were taken by him in Bolton, in this state, in January, 1864. A specimen has been seen the present autumn (October, 1869), in Cambridge, by Wm. Brewster.

Solitary Vireo. Lanivireo solitarivs Bon. This species formerly supposed to be more properly a spring and autumn visitant than a summer resident, seems to breed not unfrequently at some localities. Dr. Brewer says it is as common in summer about Roxbury as any of the Vireos, except perhaps the Red-eyed.

White-éyed Vireo. Vireo Novceboracensis Bon. As stated in my Catalogue, this species is much more common in the eastern part of the state than in the western. Like some other species, it is much more common during some years than in others. Dr. Wood has found three nests at East Windsor Hill during the last ten years, but he considers it rare there. Mr. C. W. Bennett obtained the first specimen I have known found in Western Massachusetts in May, 1867, at Holyoke. I killed a pair the last week in July in Springfield, in 1868. These I believe are the only ones as yet known from that portion of the state. In 1868 it was quite common in and about Cambridge, but this year I have not observed it.

Loggerhead Shrike. Collurio Ludovicianus Baird. (Lanius excubitoroides and $L$. elegans Swain). This species, as observed by Dr. Coues, $\uparrow$ was formerly given as a bird of New England, but deeming the authority to be highly ques- 
tionable, I omitted it from my Catalogue. As Dr. Cones remarks, New England is beyond its usual range; the nearest point heretofore given where it regularly occurs is Hamilton, C. W., where, according to Mr. Charles McIlwraith, it is not a very rare summer resident.* Mr. Charles Linclen informs me that he has this year obtained the birds and a nest containing six eggs at Buffalo, N. Y. Its occasional occurrence in New England hence becomes more probable.

On several occasions the so-called Collurio excubitoroides has been confounded by local observers with the Collurio Ludovicianus, and with very good reason, since they are undoubtedly the same. Specimens from the upper Mississippi valley, where the habitats of the two supposed species join, are with 'difficulty referred to the one rather than to the other. In habits and every particular, except in some minor differences of coloration, the two are quite alike. In fact no one seems to have insisted very strenuously on the specific distinctness of $C$. Ludovicianus and $C$. excubitoroides (or of $C$. elegans from the latter) though they have usually been presumed to be distinct. I have collected the birds in question in Western Iowa, Illinois, and in Florida; according to authors those from the first two localities should belong to $C$. excubitoroides and those from the latter to $C$. Ludovicianus. The differences between them are exceedingly slight. Specimens of the so-called C. Ludovicianus from the South Atlantic states differ from others from California and Iowa called $C$. excubitoroides not more than specimens of the latter from New Mexico do from Iowa ones, or than the two supposed species do in the average, and less than specimens firom near the assumed line of junction of their respective habitats. Audubon, it seems to me, very properly regarded them as a single species. It seems to be rare in the Atlantic states north of Washington, but in the interior reaches the Saskatchewan valley, and extends westward to the Pacific, and south to Mexico. In avoiding the

* Birds of Hamilton, C. W., Proc. Essex Inst., Vol. v, p. 87. 
North-eastern states it resembles the Eremophila alpestris, or Horned Lark (in the breeding season), Myiarchus crinitus (Great-crested Flycatcher), Centurus Carolinus (Redbellied Woodpecker), Melospiza Lincolnii (Lincoln's Sparrow), Zonotrichia leucophrys (White-crowned Sparrow), and some other species that extend much farther north in the interior than on the Atlantic coast. The Horned Lark is not known to breed regularly on the coast much, if any, south of Labrador, but in the interior it breeds abundantly on the prairies as far south as Missouri, and even in Texas. Some of the other species mentioned above do not extend farther north on the coast than New Jersey, except as stragglers, although in the interior they reach the Saskatchewan. The elimate there is certainly not warmer than that of Southern New England, and some other cause must be sought to explain such an unusual clistribution.

Red-bellied Nuthatch. Sitta Canadensis Linn. The known instances of this bird's breeding in Massachusetts are very few. Five years since, when my Catalogue was published, I knew of none, and gave it as a winter visitant, having then seen it only during the colder portion of the year. Mr. Jillson has informed me that he found its nest a few years since in Bolton. Dr. Brewer also informs me that he saw it on his place in Hingham, in July, 1867, but was unable to find its nest. Many experienced collectors of birds in Southern New England have never met with it here in sunmer, but it is known to breed (perhaps only among the Alleghanies) much farther south.

Pine Grosbeak. Pinicola eneucleator. (P. Canadensis Cab.). This northern bird has occurred within the state several times within the last five years. During the last two winters they were quite common at certain localities, but were not generally distributed. As usual, they were chiefly young birds. It seems to be of late a more regular visitor than was formerly supposed.

Purple Fincir. Carpodacus purpureus Gray. Common 
in summer in many parts of the state, and the number that breed here seems to be increasing. They usually select evergreens for their nests, and appear to more often build in the cultivated shrubbery of the towns than elsewhere. They are almost as unsuspicious as the proverbially familiar Chipping Sparrow (Spizella socialis), they often placing their nests in the hedge-rows that border frequented walks. I learn from Mr. B. P. Mann that he has repeatedly found their nests in such situations, and Mr. R. B. Hildreth has observed the same fact at Springfield. This familiar habit in the Purple Finch of California has obtained for it the name of House Finch, and it was supposed to differ greatly in this respect from the Purple Finch of the Atlantic states, before the breeding habits of the latter were so well known. It differs in this respect not apparently from the eastern bird, nor in any other way to any essential clegree, specimens from California in the Museum of Comparative Zoölogy being quite indistinguishable from others from Massachusetts. Hence its distinctive name of fiontatis becomes properly a synonym of purpureus.

For the past two winters I have observed individuals of this species at frequent intervals in Cambridge, and $\mathrm{Mr}$. Bennett has observed it at the same season about Mount Holyoke. By far the greater part, however, go further south at this season.

Nearly all observer's in Southern New England that I have met remark that this bird has greatly increased there during the last ten years; especially is it more numerous in the breeding season.

Pine Fincr. Chrysomitris pinus Bon. But a single instance of the breeding of this bird in Massachusetts has come to my knowledge - that mentioned in my Catalogue. The present year, however, they were quite common in Cambridge till the last of June, and on two or three occasions I observed them during the first half of July. I felt sure at one time that they would breed here, but if they, like the 
Yellow Bird (Astragalinus tristis), breed very late in the season, they may have retired in July farther north for this purpose, as I did not meet with them later in the season. This is very probably the fact, since Mr. William Brewster found this species breeding in August this year at Gorham, New Hampshire.

Red-poll Finch. AEgiothus linaria Cab. During the past five years this little northern visitor has been several times very numerous in Massachusetts. It was especially so during the winters of 1866-'67, 1867-'68, and quite so in 1868-'69.

A series of skins in the collection of the Museum of Comparative Zoölogy, collected in this state by Mr. C. J. Maynard, represent four of the so-called species of this group recently recognized, - the common $A$. linaria, the supposed larger Mealy Redpoll, $A$. canescens Aud.,=AE. epilipes Coues, the $A$. rostratus, and the $A$. fuscescens, described as a new species by Dr. Coues.* From a careful examination of many specimens, from the far north, as well as from Massachusetts, I cannot consider these forms as distinct species, since the differences on which they are based are very inconstant, and connected by endless intermediate stages. The extreme forms to which these several specific designations have been applied are quite different from each other, and if the differences were constant might well be regarded as distinct species. But, as already stated, the diferences are not constant, and it is almost impossible to draw a separating line between these several so-called species. $\dagger$

Red Crossbill. Curvirostra Americana Wilson. This bird, as is well known, is very irregular in its visits to this state, not only in respect to numbers but in regard to the season of its appearance. It is generally most numerous in winter, but is sometimes more or less common throughout

* See his "Monograph of the Genus Egiothus," Proc. Phil. Acad. Nat. Sci., Nov., 1865. † On this point see farther my "Notes on the Birds of Iowa, Illinois, etc.," in the Memoirs of the Boston Society of Natural History, Vol. i, pt. iv, p. 515 (foot note). 
the year; at other times very few are seen for a considerable period. Concerning this species I have received from $\mathrm{Mr}$. Maynard the following very interesting note. He says that in 1868 these birds appeared in Massachusetts "early in September, in very immature plumage, which seemed to indicate," he thought, "that they were raised in the states. But upon visiting Oxford county, Maine," he continues, "October 12th, and not seeing a single specimen of this bird (although after the 21 st the White-winged species was common) I was induced to inquire of the farmers respecting them, when I was informed that they passed through that region early in August, in large numbers, doing great damage to the oat crop. This shows that the unusual occurrence of this bird in immature plumage early in the season was owing to the early migration of northern raised birds, induced, probably, by an insufficient supply of food, which I think regulates the migrations of all northern birds; hence the irregulurity of their visits. The species in question passed entirely south of Newton (Mass.), as upon my return from Maine, November 13th, not a specimen could be found, but $C$. leucoptera was abundant. From what $I$ have seen of these two species I think the latter is generally much more boreal in its habits."*

Specimens of the Red Crossbill have been received at the Museum of Comparative Zoölogy from Massachusetts so young that it seems highly probable that they were raised here. Among them are specimens collected in Weston, in May, 1862, by the late Mr. Horace Mann. Some were so young that their bills were not fully grown, while the plumage also indicated great immaturity. It is hardly possible that they could have been born far from where they were collected. The condition of the specimens collected by $\mathrm{Mr}$. Maynard, alluded to above, seems to indicate that they also have not been long from the nest, though they may, as he supposes, have come from Maine. These facts seem to 
indicate that this species breeds at irregular times, since the eggs obtained near Milltown, Maine, by Mr. G. A. Boardman, ${ }^{*}$ were, as he has informed me, found in February, and birds hatched thus early would probably moult their nesting plumage early in summer. Mr. Maynard's specimens must have been hatched at least as late as June, and probably in July, else in respect to the time of moulting the first or nestling plumage of this species is strangely anomalous. $\dagger$

Since the above was put in type I have received from $\mathrm{Mr}$. Boardman firther information respecting the breeding of the Crossbills, as follows: "They breed all the season, from the middle of February till into May, and perhaps later."

White-winged Crossbill. Curvirostra leucoptera Wilson. This species is much less frequent in its visits than the preceding, it being, as Mr. Mayinard has observed, much more boreal, and is generally seen only in winter. Last winter they were quite numerous in the eastern part of the state, when, as he has stated above, Mr. Maynard observed them as early as the middle of November. They remained, according to the same authority, till the first of June, they being observed by him in flocks during the last week of May. He also informs me that he shot a male in fine breeding plumage the 13th of June. In the summer of 1866 he found their stomachs filled with canker worms.

Lapland Lovgspur. Centrophanes Lapponicus Kaup. This is a very lare winter visitor in the interior of the state, but rather common, according to $\mathrm{Mr}$. Maynard, at Ipswich, where he has taken half a dozen in a day, and seen many more. It associates with the Snow Bunting (Plectrophanes nivalis), and is probably more or less common in winter along the whole coast of the state.

* See American Naturalist, Vol. iii, July, 1869.

† With the above Mr. Boardman sends the following interesting notes: "The Canada Jay also breeds when the snow is quite deep, usually in March, and I think again in summer, as I have seen young birds in September. 'I have also found Raven's eggs when the snow was quite deep, and have also known the young of Mergus Americanus to be out by the middle of May, which is usually early." 


\section{THE LINGERING ADMIRERS OF PHRENOLOGY.}

BY PROF. CLELAND.

To slay those that are already slain may be excellent sport to employ the courage of a Falstaff, but the reader perusing the title of this article may perhaps be disposed to ask why the pages of this review should be occupied with the discussion of so dead a doctrine as Phrenology. The answer is, that although phrenology never had much countenance from scientific men, and has long since been banished by them, with one consent, to the limbo of exploded chimeras, yet among educated men and women not physiologists, and not pretending to know anything about anatomy, it still holds its grounds wonderfully, and counts considerable numbers of people who believe in its miraculgus skull maps; while, besides these, there is a far more numerous class of persons, including, undeniably, a certain proportion of scientific men, who, admitting that the minute division of the cranial vault into organs is untenable, yet profess belief in a larger mapping, and have no hesitation in relegating the reasoning faculties exclusively to the forehead, and the moral sentiments and volitionary power's to other parts of the brain-pan.

This state of matter does not exist without a sufficient reason to account for it. Long before the time of Gall and Spurzheim, men were in the habit, sometimes consciously, and much more frequently half unconsciously, of gauging the intelligence and moral qualities of their neighbors by their personal appearance generally, and more particularly of estimating them according to crude impressions derived from the shapes of their heads. They judged rightly enough that there was some connection between brain and mind. Mych of the evidence that the brain is the organ of the mind is so palpable that it could not remain long hid. The effects (586) 


\section{NOTES ON SOME OF THE RARER BIRDS OF MASSACHUSETTS.}

BY J. A. ALLEN.

(Continued from page 585 .

Baird's Sparrow. Centronyx Bairdii Baird. Mr. C. J. Maynard while collecting Long-spurs and Snow Buntings on the Ipswich sand-hills, December 4th, 1868, had the good fortune to shoot the first specimen* of this species thus far obtained east of the Missouri, so far as known. No other at least is yet on record, and but one other specimen seems to be extant. This is one of Audubon's types collected near the mouth of the Yellowstone, in the summer of 1843 , and now in the Museum of the Smithsonian Institution. Mr. Audubon is the only naturalist who has previously met with it. He reports it as common at the locality where he discovered it, where he obtained both males and females and its nest. $\dagger$ But very little is known respecting its migrations or its distribution. Its discovery in Massachusetts was quite unlooked for. Mr. Maynard thinks he saw others, but supposing it to be some other species he made no especial efforts to obtain them. In his notes kindly communicated to me he remarks: "I saw other specimens, and am confident that I detected it the preceding season, 1867. It is probable that it is a regular winter visitor from the north, accompanying the $C$. Lapponicus and $P$. nivalis, for it does not seem probable that it should occur regularly so far from its usual habitat - the distance being some over sixteen hundred miles - and not be found in the intermediate space." As he further observes, his specimen somewhat resembles the Baywinged Sparrow (Poocotes gramineus), with which inexperienced ornithologists might easily confound it. It is ,

\footnotetext{
* Mr. Maynard gives a good flgure of this specimen in his book on Taxidermy ("Gulde to Naturalists in Collecting and Preserving Objects of Natural History") now publishing.
}

† Birds of America, Vol. vii, p. 359, pl. 500. 
certainly nearer this than the Savannah Sparrow, with which it has been compared. "My specimen," he says, "also differs in size [from Audubon's*]. I give measurements of both for comparison, remarking that mine was measured from the fresh bird, while the other was from the skin."

\begin{tabular}{|c|c|c|c|c|c|c|c|c|}
\hline LoCALITY. & Date. & Length. & Alar ext. & Wing. & Tail. & Bill. & Tarsus. & Sex. \\
\cline { 1 - 3 } & & & & & & & \\
\hline Mouth of Yellowstone. & 1813 & 4.64 & - & 2.77 & 2.10 & .39 & .84 & - \\
Ipswich, Mass., .... & Dec. 4, 1868. & 6.30 & 11.00 & 3.25 & 2.60 & .40 & .95 & $\delta$ \\
\hline
\end{tabular}

It differed in color as well as in size from the specimen described by Prof. Baird. The former difference is doubtless due $t_{0}$ the different seasons of the year at which they were collected, and the latter to the fact of the Ipswich specimen having a more northern birth-place. That there might be no mistake, the specimen was transmitted to Professor Baird for examination, who kindly compared it with the type in the Smithsonian Institution, and reports that he found them identical.

Savannah Sparrow. Passerculus savanna Bon. Rather rare in the interior at all seasons, and, so far as I can learn, only seen there during its migrations. On the coast, however, it is one of the most common sparrows throughout the summer, where great numbers breed. I have seen it from Ipswich southward all along the coast to Nantucket Island. On the islands off the coast it is often the most numerous species of bird. The Song Sparrow, on the contrary, is more numerous in the interior, it being comparatively scarce on the islands and on the coast close to the sea.

Henslow's Sparrow. Coturniculus Henslowii Bon. This species must still be considered a rare summer visitor, though it proves to be more common than was supposed a few years since. Specimens are taken in the eastern part of the state nearly every year, where also several of its nests 
have been found. The first nest found in this state was discovered by $\mathrm{Mr}$. E. S. Wheeler, in Berlin, and the fact is recorded in the seventh volume of the Proceedings of the Boston Society of Natural History (page 137). This species was at first wrongly identified as Peucea Backmanii Aud (=P. ostivalis Baird), and as such stands recorded in the sixth volume of the same Proceedings (p. 21). The mistake was corrected, however, on p. 74 of the same volume, so that Peucea oestivalis has never been included nor referred to as a bird of Massachusetts in any of the lists of the birds of the state, or of New England.

In respect to $C$. Henslowii, Mr. Maynard informs me it has been confounded with $C$. passerinus by a number of collectors, and that it seems to be more common at some localities in the state than the latter.

White-Crowned Sparrow. Zonotrichia leucophrys Sw. Rare in all parts of the state, and thus far not known to breed in Massachusetts, though it may do so among the mountains in the western counties. Though mentioned by Dr. Coues as "usually common, but of somewhat irregular occurrence" in New England, * the score or more of collectors with whom I am acquainted all look upon it as one of our rarest species in Massachusetts. Some have never met with it. More to the westward, however, it is quite common. In Wayne county, New York, I found it as numerous in May, 1867, as the White-throated Sparrows usually are in New England.

White-throated Sparrow. Zonotrichia albicollis Bon. A pair of these birds, probably the same pair, has been observed by Mr. R. B. Hildreth at Springtield during the last three summers. Though he has not succeeded in discovering their nest, he this year observed them feeding their scarcely fledged young. He reports that they have become very familiar and readily answer his call. Though breeding nu- 
merously in Northern New England, Springfield is considerably south of their customary breeding range.

Sharp-tailed Finch. Ammodromus caudacutus Swain. Some half a dozen nests and as many pair's of the birds were obtained the present year, by Mr. H. W. Henshaw in the Charles River marshes in Cambridge. These are the only recent instances known to me of the fiuding of the nest of this species in Massachusetts. None of the Seaside Finches were observed, though they were formerly known to breed in the Chelsea marshes, and probably do still.

Tree Sparrow. Spizella monticola Baird. I mentioned in my Catalogue that a nest of this species was found in this state in 1855 by Mr. E. Samuels, there being a record to that effect in the fifth volume of the Proceedings of the Boston Society of Natural History (p. 213). I have since learned from Mr. E. A. Samuels that this was a case of malidentification, the nest and eggs being really those of the Chipping Sparrow (Spizella socialis). Dr. Brewer confirms the latter account, and says he has the nest in his possession.

Lincoln's Sparrow. Melospiza Lincolnii Baird. The first record of the occurrence of this species in Massachusetts is given in my Catalogue, at which time I had taken three specimens at Springfield. It has since been taken by Mr. S. Jillson, at Hudson,-one specimen in May, 1867, and another in May, 1868. In $1867 \mathrm{I}$ took it in May in Wayne County, N. Y., when it appeared to be not uncoinmon, and in Northern Illinois the same year I found it numerous.

Swamp Sparrow. Melospiza palustris Baird. In the "Addenda" to Dr. Cones" "List of the Birds of New England" I stated I had never met with this species in the breeding season. I have since learned that it is not at all uncommon at that season at several localities in the eastern part of the state; some years it breeds quite numerously in the Fresh Pond marshes.

Black-throated Bunting. Euspiza Americana Bon. Since the publication of my Catalogue, Mr. C. W. Bennett 
has taken this species at Holyoke,-a single specimen in May, 1866. Dr. Brewer informs me he has found it breeding at Hingham. The species is still known, however, as only a straggler from the southward.

Cardinal. Red Bird. Cardinalis Virginianus Bon. Four specimens of this bird were taken near Springfield in October, 1866. Mr. W. H. Niles observed it at Belchertown the last week of October, 1868, and at Southampton May 5th, 1869. As these form all the recent authentic instances of its occurrence in the state, it can only be regarded as an accidental visitor. It has been questioned whether in the previous instances of its capture here the specimens taken were not hirds that had escaped from cages. In all probability they were, however, wild birds.

European House Sparrow. Passer domestica Leach. The few pairs turned loose in the Boston Common a few years since seem to be slowly increasing in numbers, and bid fair to be of great service in checking the ravages of several species of caterpillar's that now greatly injure the foliage of the shade trees. These interesting birds are now frequently observable both on the Common and in the Public Garden.

European Goldfinch. Carduelis elegans Steph. February 28 th, 1865 , I saw a single male on Quincy street, Cambridge, that had probably escaped from a cage. It was feeding on the seeds of the larch and appeared fully at home. Its notes first drew my attention to it, which, while so much resembling those of our common Yellow Bird, yet differ from them in surpassing in sweetness the pleasant warble of that favorite bird. I doubt not that if a considerable number of European Goldfinches should be introduced into New England the spécies would soon become acclimated and generally distributed.

Serin Finch. Serinus meridionalis Brehm. A specimen of this European species was taken near Springfield in November, several years since. It may have been a cage bird that had escaped. 
Yellow-Headed BlackBiRd. Xanthocephalus icterocephalus Baird. The wings, tail and feet, of a specimen of this species taken in Watertown, in October, 1869, were shown me a few weeks since by Mr. C. J. Maynard. Although the whole bird was unfortunately not preserved, its identity could be readily determined. This is the first known instance of the occurrence of this species in New England, but Mr. Cassin* states that several have to his knowledge been taken near Philadelphia. Its usual eastern range, as ornithologists well know, is the vicinity of Chicago, it being essentially a prairie species.

Boat-tailed Grackle. Quiscalus major Vieill. I now seriously question the occurrence of this southern species in Massachusetts, or anywhere in New England, as even an accidental visitor. I gave it as such in my Catalogue, but a reëxamination of the evidence has led me to my present opinion. I think the cases cited by Peabody $\nmid$ and Linsley $\ddagger$ (under Q. baritus) as well as that of Mr. Samuels, refer only to the common Crow Blackbird or Purple Grackle.

Spruce Partridge. Canace Canadensis Bon. The occurrence of this northern species in the hemlock woods of Gloucester in 1851 was recorded by Mr. F. W. Putnam.\| This instance is cited in my own Catalogue, and by Dr. Coues in his "List of the Birds of New England." A second instance is to be now added, as I have learned from Mr. S. C. Martin that a bird of this species was shot in November, a few years since, in Roxbury. These two instances seem to be all thus far known, and only give it a place on our list as a very rare, accidental visitor. I have, however, recently learned from Mr. Wm. Brewster, of its capture near Portland, Maine, in the autumn of 1868 , - a locality much south of its usual range.

* Proc. Phila. Acad. Nat. Sci., Vol. xviii, p. 11, 1866.

†Rep. on Orn. Mass., p. 285.

$\ddagger$ Amer. Journ. Sci. and Arts, Vol. xliv, p. 260.

|| Catalogue "Birds of Essex Co.," Proc'd's Essex Inst., Vol. i, p. 224. 
The Ptarmigan (Lagopus albus), captured at Manchester in May, $1859,{ }^{*}$ is supposed, Dr. Coues states, "to have been brought alive from Labrador or Newfoundland, and escaped." $\dagger$

Great White Heron. Herodias egretta Gray. To the previously recorded instances of the capture of this beautiful southern Egret in this state may be added the following. Two immature specimens were taken near Hudson by Mr. S. Jillson in 1867, and several others seen there. A fully plumaged male was also taken in Ashland in May several years since by Mr. A. L. Babcock, and another near Lynn, by $\mathrm{Mr}$. N. Vickary. New Jersey seems to be the most northern point on the Atlantic coast where these birds breed, or at which they can be considered as regular visitors, yet this species, as well as the Snowy Heron (Garzetta candidis$\operatorname{sima}$ ), have recently been captured in Nova Scotia. $\ddagger$

Little Blue Heron. Florida ccerulea Baird. - In addition to the previously recorded instances of its occurrence in Massachusetts, Mr. Maynard informs me he has recently seen it on one or two occasions in autumn.

Yellow-Crowned Night Heron. Nyctherodius violaceus Reich. Mr. N. Vickary, of Lynn, the well known taxidermist, informs me that in October, 1862, he shot a fine specimen of this bird in Lynu. Though occurring occasionally as far north along the coast as New York, I have learned of no other instance of its capture in New England.

Glossy Ibrs. Ibis Ordii Bon. In addition to those previously recorded as having been captured in Massachusetts, a specimen was taken in Nantucket, September, 1869. It was also taken, as I learn from Mr. N. Vickary, in New Hampshire, in October, 1858, by Dr. Palmer.

Wilson's Plover. Ochthodromus Wilsonius Reich. The usual northern limit reached by this bird seems to be the

* F. W. Putnam, Proc. Essex Inst., Vol. i̊, p. 378.

† Ibid., Vol v, p. 289.

$\ddagger$ J. Matthew Jones, Trans. Nova Scotia Inst. Nat. Sci., Vol. ii, pt. 2, p. 72 (1868). 
coast of New Jersey, where it is said to breed.* In my Catalogue $I$ inserted it as a bird of this state on the authority of Dr. Brewer, who, according to Mr. Peabody, found them abundant at Nahant in August, 1838. But Dr. Brewer wrote me under date of May 8th, 1869, that "Wilson's Plover is not a Massachusetts bird, so fur as I know." Dr. Wood informs me that "Wilson's Plover is abundant in August on Long Island," and Mr. Linsley has recorded it from Stratford, Connecticut. It hence seems unquestionable that they sometimes occur in Southern New England, and it would not be strange if they should occasionally reach the coast of Massachusetts. $\dagger$

BlacK-NeCKed Stilt. Himantopus nigricollis Vieill. Mr. G. A. Boardman informs me that he once saw two specimens of this species in Boston Market that were killed in this state. I have also learned from Mr. Maynard that it is well known. to the gunners of Ipswich, who occasionally meet with it, and by whom it is ironically named "Humility." It appears to be, however, one of the rarest of our visitors, it being properly a southern and south-western species.

Sanderling. Calidris arenaria Illiger. A few specimens of this species and of the Semipalmated Sandpiper (Ereunetes pusillus Cass.), and the Solitary Sandpiper (Rhyacophilus solitarius Baird), were taken by Mr. Maynard and myself at Ipswich in June, 1868. The last mentioned may have been breeding, as the Massachusetts coast is within its usual breeding range, but the others appeared to be only stragglers that were not breeding, all, apparently, being immature birds. The first of these is well known to breed on the coast of Maine, where Prof. Verrill gives it as abundant in summer. In some notes hastily penned for Dr. Coues' "Addenda" to his "List of the Birds of New England," written from memory (at the time of writing them I was on

* Dr. C. C. Abbott, Geology of New Jersey, Appendix.

t Compare with this Dr. Coues' remarks on this species in his "List of the Birds of New England," 1. c., p. 291. 
a journey and my notes were inaccessible), I state that $A c$ todromas Bonapartei was among the birds seen by us in summer on the Massachusetts coast. This I think is an error of memory, as I do not find it recorded in my note book, and no specimens of it were taken. Arquatella maritima is also there mentioned as having been seen; though this is probable, I should add that it does not rest on positive evidence, as none were taken.

Stilt SAndpiper. Micropalama himantopus Baird. As this southern species has been twice taken recently at Rye Beach, New Hampshire, by Mr. William Brewster, the question as to whether it should be included among the birds of New England is now settled. As it must have passed through Massachusetts, it is properly to be included in our list, though not yet recorded as actually taken in this state.

Yellow Rail. Porzana Norceboracensis Cass. Taken by Mr. C. J. Maynard, September 8th, 1868, in a dry field in Newton.

Common Gallinule. Gallinula galeata Bon. I learn from Mr. Ruthford Deane of Cambridge that he shot a young bird of this species in Fresh Pond on the 3d of September, 1868, and saw two others in the latter part of the same inonth. 'The 9th of October of the same year he informs me his friend William Brewster shot one which he obtained, and wounded another, at the same locality. Also that the latter observer saw an old bird there on the $3 d$ of June, which Mr. Deane believes to have been the parent of these young. As this species regularly breeds in New Jersey, it is not improbable that straggling pairs may now and then rear their young in Massachusetts, but this is much beyond its usual breeding range.

Canvas-Backed Duck. Aythya vallisneria Bonap. It is stated in my Catalogue that this species was taken near Springfield by Dr. Wood. 'This proves to be an error, as Dr. Wood has since informed me he never knew it taken nearer that locality than ten miles above the mouth of the 
Connecticut. So far as I have been able to learn by careful inquiry, this species is much less common in New England than several authors represent. It seems to be but an accidental or very rare visitor.

American White Pelican. Pelecanus erythrorhynchus - Amer. Gmelin. I learn from Mr. S. C. Martin that a flock of f. Wirt. thirteen individuals visited Nantucket Island during a heavy storm a few years since. After being repeatedly fired at one of them was finally killed, near Brant Point light-house. Mr. C. J. Maynard also informs me that several were seen at Ipswich at about the same time. The only other recent instance of the capture of this species in New England seems to be that at Calais, Maine, given by Mr. G. A. Boardman.* It seems to be entirely accidental here now, although formerly, according to early writers, of not unfrequent occurrence. It still ranges, however, over the greater part of the continent.

Herring Gull. Larus argentatus Brünn. Although large numbers of this species spend the summer along the Massachusetts coast, I have not been able to find any breeding here. Those seen in summer are all immature birds, generally in brown plumage. Although they once unquestionably bred on our coast, none now appear to rear their young nearer than the northern part of the coast of Maine. Hence the occurrence of large numbers of immature birds in summer two hundred miles south of the nearest breeding grounds of the species is a fact of considerable interest.

Some year's since Dr. Elliott Cones separated the American Herring Gull from the European, under the name of Larus Smithsonianus, he supposing it to differ in certain points of coloration from the European bird. $\dagger$ Unfortunately, these differences do not prove constant, specimens identical in every particular with the typical European $L$. argentatus of Coues occurring not unfrequently on the New

* Proc. Bost. Soc. Nat. Hist., Vol. ix, p. 130.

† Revision of the Gulls of North America, etc., Proc. P. A. N. S., June, 1862, p. 296. 
England coast. As I have already called attention to this fact* I will only add that during last winter additional specimens of this character were obtained by me in Cambridge.

Laughing Gull. Chroecocephahus atricilla Lawr. This bird now breeds on the Massachusetts coast very sparingly, it having been nearly extirpated by the incessant persecution it suffers from "eggers" during the breeding season. A few pairs were observed last year on Muskeget Island, by $\mathrm{Mr}$. Maynard and myself, and a few of its eggs obtained, about July 1st. As they had previously been repeatedly robbed, "eggers" almost constantly haunting the island, they were extremely shy. Another small colony of this species, I have learned from Mr. L. L. Thaxter, breed on the islands near Tennant's Harbor, Maine.

In my Catalogue I by some mistake gave this bird as occurring in winter. Though said by Mr. Boardman to be resident in the vicinity of Calais, Maine, I have as yet been unable to learn of its occurrence in this state except in summer. My earlier impression that the species was resident in Massachusetts I have since found was wrongly founded.

Common Tern. Sterna hirundo Limn. This interesting bird must soon be numbered among the species which persecution has driven from the state during the breeding season, unless some effective mode of protecting it during the breeding season is soon adopted. At present it is only found at a. few localities, chiefly on Muskeget and the neighboring islets; a few only breed at different points along Cape Cod and at Ipswich. Almost everywhere they are more or less persecuted, and at Muskeget this and the other species of Terns that breed there are so systematically robbed of their eggs that if they succeed in rearing any young at all it is only after having been several times deprived of their eggs. Muskeget is a small, barren, sandy, crescent-shaped island, about two miles in length, with, in its wider part, a breadth

* Memoirs Bost. Soc. Nat. Hist., Vol. i, p. 520.

AMER. NATURALIST, VOL. III. 
of about half a mile. Only thinly clothed with beach grass, it is naturally well suited to the breeding habits of the several species of Terns that regularly resort to it to breed. Though uninhabited by man and quite distant from large towns, the birds are far from secure there. Besides the daily visits of small egging parties during the proper season from Nantucket and other near points, excursions are made by large parties from distant places to the island for the express purpose of participating in the novelty of an egg hunt, with sad results to the birds, as above stated. This is certainly a matter that the "Society for the Prevention of Cruelty to Animals" should look after.

Arctic Ters. Sterna macroura Naum. In company with the preceding are found a certain proportion of these birds. Last year Mr. Maynard and myself found them breeding apart from the others on the island of Muskeget. We also found them at Ipswich, as Mr. Maynard has also done the present year. In voice and habits, however, the two seem not to differ in the slightest, nor in general size. In color they only differ as young birils often do from older ones of the same species, the $S$. macroura corresponding to the mature form and the S. hirundo to the younger. The tarsi and the bill in $S$. macroura seemed to be generally the shorter, but not always. In color S. macroura was always the brighter, without the black tip of the bill seen in $S$. hirundo; the black on the head is generally more intense and better defined; the sooty wash beneath is much deeper, and the white of the rump purer. The tarsus was not only shorter but had a roughened appearance not seen in the other, they differing in the latter respect much as young birds in this and allied families frequently do from those perfectly mature. On the whole there seemed to be good reasons for believing them to be simply different ages of the same species. The young of S. macroura being then unknown, it was evident that the discovery of them would afford decisive evidence on the point in question. Fortunately this 
year Mr. Maynard succeeded in obtaining the young of $S$. macroura at Ipswich, when they were just able to leave the nest. A comparison of these with the young of $S$. hirundo of corresponding age, or even with mature $S$. hirundo, leaves no question as to their distinctness. 'The differences between the young of the two are as great as between the adult. In these nestlings of $S$. macroura the color of the rump is as different from that of the back as it is in the adult, the plumbeous bluish mantle not being continued to the tail as in S. hirundo.

The distinctive differences then between them may be stated thus :

S. macroura has the under parts strongly tinged with plumbeous, with the throat and under tail coverts abruptly white, while in S. hivunclo the under parts are faintly washed with plumbeous which fades gradually into white on the throat and under tail coverts. S. macroura has the shorter tarsi, and the shorter, smaller and more delicately shaped bill; in color the bill of the latter is uniformly carmine, not coral red with a black tip, as in the other, and the tarsi and feet deep vermilion, almost lake (not light vermilion as in S. hirundo), and roughened. The rump is abruptly white at all ages, while in $S$. hirundo it is dilute plumbeous, shading gradually into the color of the back. In size and general proportions there are no essential differences between them.

So long as the young of $S$. macroura was unknown, it seemed that the differences in color between the young of $S$. livundo and the adult of that species, if carried a little further, would result in a form, so far as color is concerned, exactly like $S$. macroura.*

Rosente Terv. Sterna paradisea Brünn. Occurs plentifully on Muskeget Island during the breeding season. Was also taken by Mr. Maynard and myself at Ipswich in June,

\footnotetext{
* For an excellent revision of the Tern's of North America, see Dr. Elliott Cones' paper on this subject in the Proceedings of the Philadelphia Academy of Natural Sciences, 1862 , p. 535 .
} 
1868. Heretofore generally considered rare in this state, which appears to be its northern limit.

Sandwich Tern. Sterna cantiaca Gmelin. (Sterna acuflavida Cabot.) Mr. Nathaniel Vickary, of Lynn, has a specimen of this species in his collection, which he shot at Chatham, in August, 1865. The usual northward range of this southern species does not extend beyond South Carolina, and is now for the first time reported as captured either in this state or in New England.

Short-tailed Tern. Hydrochelidon fissipes Gray. Occasional, chiefly after the breeding season. Mr. C. J. Maynard has taken it at Ipswich, and probably it occurs all along the coast, though its existence here has been questioned.

Sooty Tern. Haliplana fuliginosa Wagl. (Sterna fuliginosa Gm.) This species was given in my list as a rare summer visitor, on the authority of $\mathrm{Mr}$. E. A. Samuels, who - he having found two young birds he referred to this species-informed me that it bred on Muskeget Island. As it is a southern species, and is only occasional on the coast of New Jersey, which is north of its breeding range, it is somewhat doubtful whether it is entitled to a place in a list of the birds of Massachusetts. Respecting this species Dr. Brewer has written me as follows: "It does not and never did breed on Muskeget, nor do I believe it ever comes here." Since the equally southern Sandwich Tern has been taken here, the probability of this being also an accidental visitor is increased.

Great Auk. Alca impennis Limn. This species has recently been made known as a former inhabitant of Massachusetts. Professor Wyman first discovered its remains in New England at Mount Desert, in the Indian shell-heaps.* Mr. F. W. Putnam reports that a humerus of this bird was found in August, 1868, in the shell-heaps of Ipswich, by Professor Baird. $†$ Mr. Maynard and myself found frag-

* American Naturalist, Vol. i, p. 578.

† Coues" "Birds of New England," Proc. Essex Inst., Vol. v, p. 310, foot note. 
ments of several different bones of this bird in June of the same year at the latter locality, where also Mr. Maynard had obtained them in previous years.

It appears, from information received too late to enable me to insert them in their proper places, that the following species should also be added to those already recorded from Massachusetts :

Swallow-Tailed Hawk. Nauclerus furcatus Vigors. From Mr. Bennett I have received a description of a hawk seen near Whately, not long since, that was unquestionably of this species; but, so far as I am aware, it has not yet been taken in Massachusetts. Although a southern species, it is rather common in the interior as far north as Iowa, and stragglers have been taken along the Atlantic coast as far north as New York. It can only occur in New England, however, as an extremely rare visitor.

A South American Humming Bird, Argytria maculata Cab. and Heine, was taken in Cambridge in August, 1865, by $\mathrm{Mr}$. Wm. Brewster. It seems almost incredible that so small a bird should wander so far from its usual haunts, since its real habitat is the northern countries of South America; yet after carefully investigating the history of this specimen, it seems to me there is no reason to doubt its capture in this state. It is possible, of course, that it may have been brought here in a cage and have escaped, but that such was the case does not appear to be at all probable.

Gray Kryg Brrd. Tyrannus Dominicencis Rich. A specimen of this species, now in Mr. Vickary's collection, was shot in Lynn, early in October, 1869, by Mr. Charles I. Groodale. Although essentially a West Indian species, it is not uncommon in Florida, but only occasionally ranges so far north as Charleston, South Carolina. It hence forms one of the most remarkable additions to the fauna of the state yet recorded. The specimen was evidently a young bird, or a bird of the year. 
The following facts also came to hand too late to be inserted in their proper connection :

Black Vulture. Cathartes atratus Less. Mr. S. Jillson informs me that a specimen of this species was killed in Hudson a short time since, and that several others were seen there which no one cared to shoot. Mr. G. A. Boardman has also recently taken it near Calais, Maine.* Though rather more southern in its distribution than its near relative the Turkey Buzzard ( $C$. aura), it seems to be much more frequently met with in New England, and has been taken as far north as Nova Scotia.

BarN Owl. Strix pratincola Bon. A specimen of this species, Mr. Vickary informs me, was taken in Lym six years since, by Mr. James Teal, and is still in a private collection in that town. This forms the second specimen of this species thus far known to have been taken in Massachusetts.

Tengmaly's OwL. Nyctale Tengmalmii Bon. Mr. Vickary has a specimen of this rare winter visitor that he informs me was shot in Lymn, in 1863, by Mr. J. Southwick. I have also seen two other specimens of this bird that have been recently killed in this state.

This is the species referred to in my Catalogue as Richardson's Owl (Nyctale Richardsonii Bon.), which is the name of late generally given to it by American authors. It does not, however, upon comparison, appear to be distinct from the so-called Tengmalm's Owl of Europe, with which, previous to 1838 , it was by all writers considered to be identical.

From information received since the first part of this paper went to press, several species whose occurrence in Massachusetts was unknown to the writer at that time (two of them having been for the first time captured here since that part of the paper was written) have been added to the

* See American Naturalist, Vol. iii, p. 498, November, 1869. 
Massachusetts fauna, so that a revision of a portion of that part is already necessary. * The whole number of species is now three hundred and eight, or-excluding the House Sparrow (Passer domestica), which has been introduced by man, the Goldfinch (Carduelis elegans), the Serin Finch (Serinus meridionalis), and the South Anerican Humming Bird, which may also have been (but probably were not) similarly introduced - three hundred and five, instead of three hundred, as there stated, or two hundred and ninetysix, as given in my Catalogue. Three of the species recorded in the Catalogue being now no longer counted, the whole number of species of birds added to the fauna of the state since 1864 is sixteen; eleven, and probably fifteen, of which can unquestionably be legitimately counted.

In this connection it may be asked, in view of the numerous recent additions to the bird fauna of this state: Are not certain species that were formerly regarded as scarce here now increasing in numbers? and is it not probable that some of the species recently detected have but recently made their first appearance here?

It is probable that a few species have recently increased and still are increasing in numbers; but it seems more probable that in most cases this apparent increase is mole the result of the much greater number of observers now in the field than formerly, and the consequently much greater amount of attention recently given to the ornithology of our state. Doubtless other species will soon be detected here.

The occurrence of several species in Massachusetts whose

* The following corrections should be made in the first two parts of this article:Page 512, last line, for seven read twelve. Page 512, add to the second foot note, Buteo Cooperi, Tyrannus Dominicensis, Xanthocephalus icterocephalus, Nyctherodius violaceus, Sterna cantiaca. Page 513, change the sentence beginning in the ninth line to read as follows: Others now added, especially the Californla Hawk (Buteo Cooperi). Baird's Finch (Centronyx Bairdii), and the Gray Kiug Bird (Tyrannus Doninicensis), are sim. llar and equally remarkable cases of western and southern species straggling far beyond their usual range. Page 513, 19th line, for specimens read species. Page 513,25th line, for three hundred read three hundred and fifteen. Page 516, 1st line, for 1862 read 1861. Page 518, 12th line, for characteristic read well-marked. Page 582, 19th line, for frontalis read Californicus. Page 583, 16th line, for epilipes read exilipes. Page 584, 2d line from bottom, for have read had. Page 585, 8th line, dele of. 
usual range does not extend much to the eastward of the Mississippi River, and of two not usually found east of the Rocky Mountains, and of other's that rarely occur north of Florida, shows the possibility of a species becoming widely diffused over districts farorable to its existence by occasional migrations.

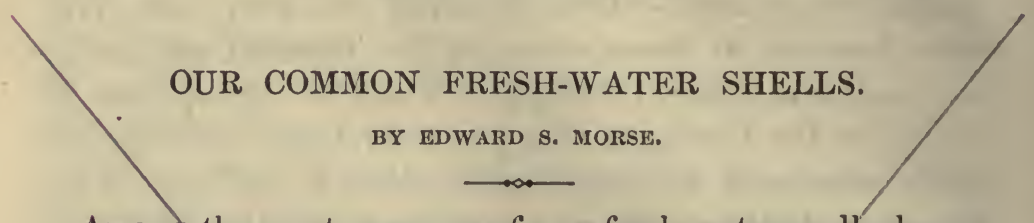

Arong the most common of our fiesh-water mollusks are the air-breathing water snails. Muddy lakes, ponds, streams and marshes, being their favorite abodes, and even ditches sometimes swarming with them. It would be difficult to find a body of fresll-water that did not contain certain representatives of this class.

Their shells are quite uniform in fexture and color, containing but little lime, and for this reason are quite light, and even in some species slightly elastic. They are quite hardy in confinement, and a ferr specimens secured in early spring time will afford many pleasant hours of amusement to those interested in watching their habits. They have to come often to the surface of the water to breathe, and it is curious to watch them during this operation. The snail with its broad disk slowly sweeping along the glass, feeding at the same time by lapping up whatever particles of food it may meet with. As it nears the surface the shell is inclined in such a yay that the aperture is brought almost out of water, and then a funnel-like process is opened in such a way that the air enters the respiratory cavity, while the water/seems to be repelled by the edge of the funnel.

During the spring time the eggs are laid and attached to some substance by a transparent mucous. If laid upon the glass walls of an aquarium, or the sides of a glass dish, 


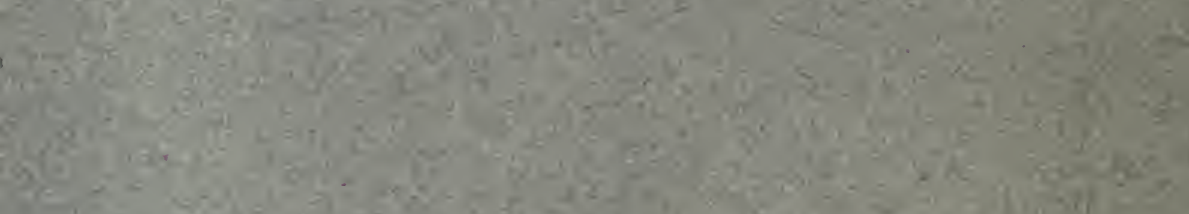

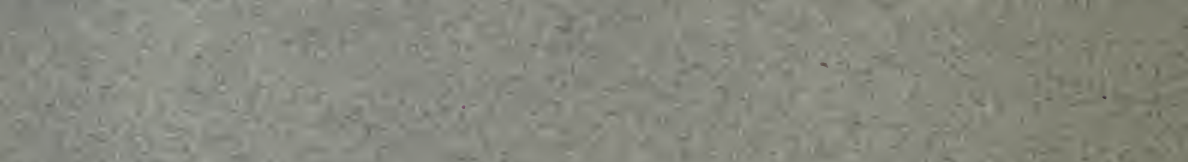

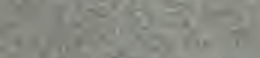

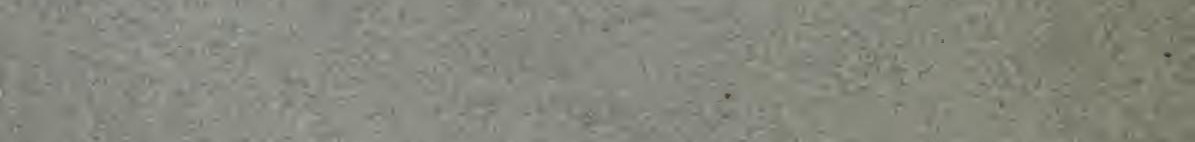

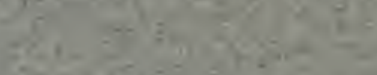

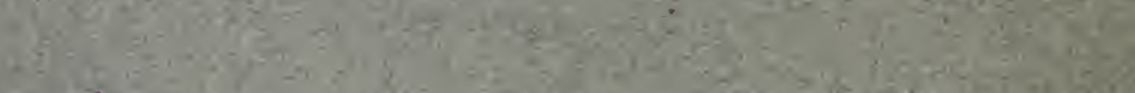

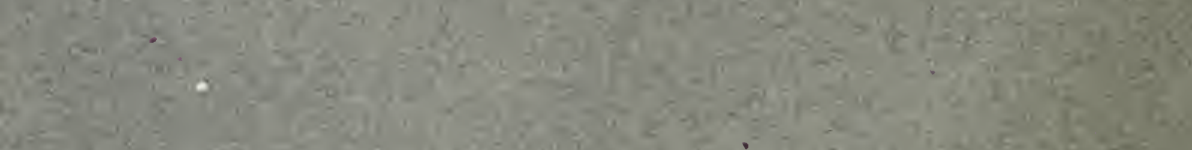

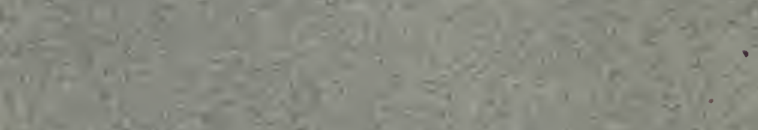

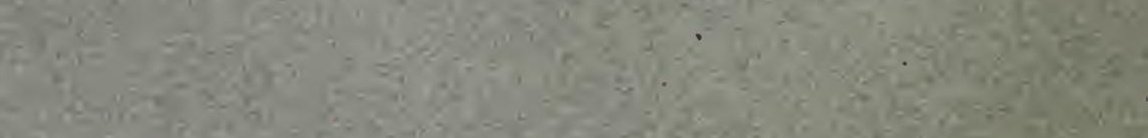

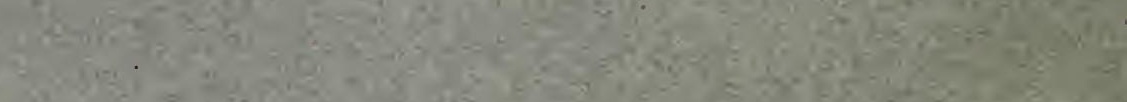

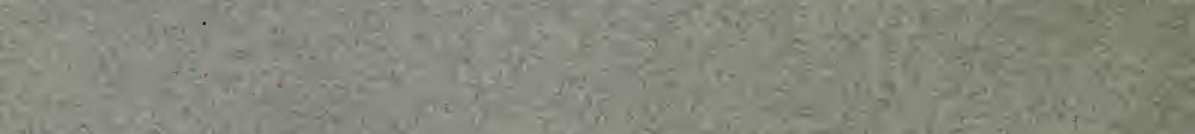

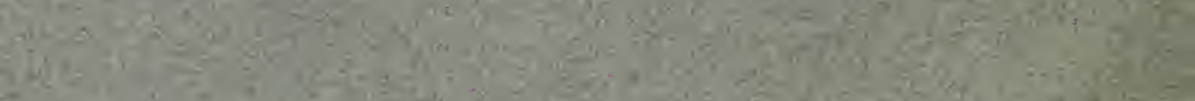

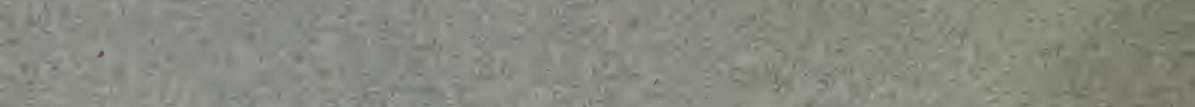

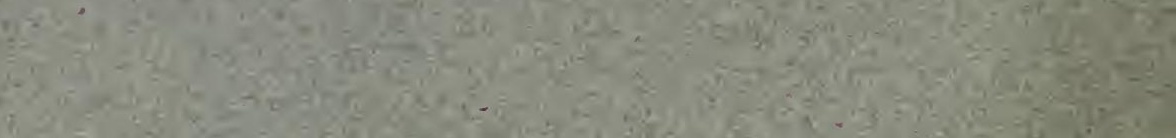

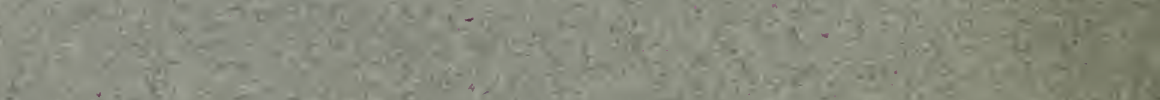

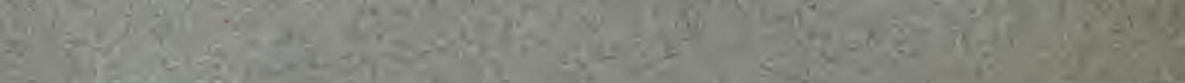




\title{
A $\operatorname{LIST}$
}

OF THE

\section{BIRDS OF MASSACHUSETTS,}

\section{WITH ANNOTATIONS.}

\author{
By J. A. ALLEN.
}



A List of the Birls of Massachusetts, with Annotations.

\section{By J. A. Allen.}

During the last ten year's not less than thirty-four species have been added to the avian fauna of Massachusetts. A few included in the earlier lists are now currently recognized as merely nominal, and a few other's prove to have been inserted on erroneous identifications, or on unsatisfactory evidence. In view of the many additions and other changes made since the publication of the last general catalogue of the birds of the state, a new list seems desirable. In the present attempt to supply such a list I have endeavored to distinguish rigidly between such species as have been either actually taken, or observed under circumstances that render an erroneous identification almost impossible, from those of merely probable occurrence. I have hence separated the species below enumerated into several categories, namely: (1) species authenticated as birds of the state; (2) species of probable occurrence; (3) extirpated species; (4) species introduced, or probably introduced, by man's agency; (5) hypothetieal and doubtful species.

The thoroughly authenticated species number three hundred and sixteen, besides several additional varieties. Of these about one hundred and thirty-five are known to breed within the limits of the state; some of them, however, somewhat sparingly and irregularly, or only in the more elevated portions of Berkshire County. About seventy fall into the cliss of accidental or extremely rare 
visitors, and hence form, numerically, so far as individuals are concerned, no very important part of our fauna. The recorded instances of their capture, however, probably by no means fairly indicate the frequency of their occurrence.

The species indicated as of probable occurrence number twenty-four. One-fourth of these have already been taken on the very borders of the state (Suffield, Conn.), so that it seems almost finical to exclude them from the list of those known to occur in Massachusetts. Several others are southern species that have been taken in New Hampshire and Maine, to reach which points they in all probability passed through Massachusetts. The remainder are largely pelagic, and since they are of no interest or value to the sportsman, and are rarely accessible to the collector, the fact that we have no positive record of their capture within the state scarcely outweighs the strong probability of their occurrence here, as indicated by their known general range and habits. Hence at least seveneighths of the species placed in the list of those probably occurring may certainly be considered as fairly entitled to be ranked as birds of the state. Adding to these four that have become extirpated raises the total number of species for the state to about three hundred and forty.

Several other species more or less commonly recognized as birds of the state I have considered as having no, or only very slight, claims to be so considered. Two of these (Myiodioctes minutus and Empidonax pygmaus) I regard as hypothetical; another (Thaumatias linncei), as of doubtful record as taken in the state; another (Passer domesticus) is a well known introduced species, and two or three others may have escaped from cages.

The ornithology of the eastern portion of the state may now be regarded as pretty thoroughly known; that 
of the central portion, though less well known, can scarcely differ much from that of the eastern. The region west of the Connecticut valley still offers an interesting field for investigation. Owing to the elevated, mountainous character of a considerable part of this area many species must regularly breed there that do not commonly pass the summer in the more easterly portions of the state. This, in fact, is known to be the case with a few, and is inferred for others. What is needed now to complete our knowledge of the ornithology of Massachusetts are exhanstive lists of the birds of at least two localities in Berkshire County, - one near its northern boundary and the other near its southern. It is to be hoped that not many years will pass before these desiderata will be supplied.

Within the last ten years three new species have been described from specimens first taken in Massachusetts. While it is hardly probable that others yet remain to be discovered, quite a number of stragglers from the far West and South, and possibly from the Old World, will doubtless yet be added to the already long list of accidental visitors. ${ }^{1}$

At the risk of extending these preliminary remarks somewhat unduly I append a brief historical summary of the literature of the subject under consideration. The

\footnotetext{
1 In this connection it may be interesting to note, as an indication of how rapidly our knowledge of the distribution of our birds is increasing, that of twentynine species withdrawn scarcely two years since from the list of New England birds, by one of our most eminent authorities, because he could find no satisfactory evidence that they had ever been taken in New England, over one-third have since been reinstated in consequence of their actual capture within these prescribed limits having been made knowi within this short period. Out of fourteen "challenged" land birds (Passeres and Waders) nine have already been placed on the record as actually taken, in some instances at several different localities, and in numbers ranging from three to five and even eight individuals. I mention this not in the spirit of criticism, but simply as an interesting fact, for I agree with the author in question that their previous record as birds actually taken in New England was, in nearly every instance, open to serious doubt.
} 
first formal list of the birds of the state was prepared by Dr. Ebenezer Emmons, and published in 1833 in Prof. Hitchcock's "Report on the Geology, Mineralogy, Botany, and Zoology of Massachusetts" (pp. 545-551). This contained one hundred and sixty species, all but two of which were valid. Excluding the two synonyms, all but one (Rhynchops nigra) have since been confirmed as inhabitants of the state. The list was only very sparingly annotated, but symbols were employed to indicate whether the species were rare or common, resident or migratory, or whether known to breed in the state. This list, so far as it goes, is remarkably free from errors.

The same year (1833) Mr. Thomas Nuttall published a paper (written, it appears, in 1831) in the "Memoirs of the American Academy of Arts and Sciences" (2d Ser., I, pp. 91-106), entitled "Remarks and Inquiries concerning the Birds of Massachusetts," in which he added six valid, and three nominal, species to those mentioned by Dr. Emmons.

Four years later (in 1837) Dr. T. M. Brewer contributed to the "Boston Journal of Natural History" (I, pp. 435-439) a paper having the title "Some Additions to the Catalogue of the Birds of Massachusetts in Prof. Hitchcock's Report, etc." These additions comprised nominally forty-five species, about one-third of which were given on the authority of Audubon and Nuttall, and a number of others were included inferentially or on evidence of a somewhat traditional character. Three had been given (under other names) by Dr. Emmons, and two still lack confirmation as birds of the state. Only thirty-four were thus added to the number previously recorded by Nuttall and Emmons, raising the number at this time known to inhabit the state to one hundred and ninety-seven. 
In 1839 appeared Rev. W. B. O. Peabody's "Report on the Ornithology of Massachusetts" (Rep. on Fishes, Reptiles and Birds of Mass., pp. 259-404), in which were enumerated two hundred and eighty-four species as occurring or probably occurring in the state. Of these, twenty prove to have been wrongly included (more than this number were given inferentially), and thirteen others are synonyms, leaving only two hundred and fifty-one valid and properly included species.

The next enumeration is that of Mr. F. W. Putnam's "Catalogue of the Birds of Essex County" (Proc. Essex Institute, I, pp. 201-231), published in 1856, in whiich two hundred and forty-five species are given as found in Essex County, while the Appendix adds forty-eight others as found in the state, making two hundred and ninetythree in all. The Essex County list includes but a single nominal species and only four that have not been confirmed by subsequent capture, or that can be considered as in the least degree open to doubt, while only two can be regarded as beyond question erroneously included. The supplemental list is compiled mainly from Peabody, Nuttall, and Audubon, and contains a dozen or more species that are either merely nominal, or that still lack confirmation as birds of Massachusetts, leaving about two hundred and seventy-five as the number of satisfactorily authenticated species.

In 1864 Mr. E. A. Samuels published his "Descriptive Catalogue of the Birds of Massachusetts" (Agric. of Mass., Sec'y's Rep. for 1863, App., pp. xvii-xxix), numbering two hundred and sixty-nine species. Of these, three are now regarded as nominal, and five or six others have not been confirmed as occurring in the state, although given by Peabody and some other previous authors. Deducting these leaves about two hundred and sixty, or eighteen less 
than were correctly included in Mr. Putnam's list eight years earlier.

Almost simultaneously with the appearance of $\mathrm{Mr}$. Samuel's list appeared my "Catalogue of the Birds found at Springfield, Mass., with Notes on their Migrations,

- Habits, ete. ; together with a List of those Birds found in the State not yet observed at Springfield" (Proc. Essex Institute, IV, July, 1864, pp. 48-98). In this paper I gave one hundred and ninety-five as found at Springfield, and two hundred and ninety-seven ${ }^{2}$ as inhabitants of the state. The Springfield list included one species (Empidoriax acadicus) given erroneously, but which has since been taken within the area covered by the list, and some others have since been added. In the supplemental list three species were given that I now regard as synonyms, and some eight or ten others were included on the authority of Nuttall, Peabody, Audubon, Cabot, Bryant, and Brewer, of which there is no recent record of their capture, but which (with perhaps two, or possibly three, exceptions) are very likely to occur. Excluding, however, all these there still remain two hundred and eightytwo thoroughly authenticated as birds of the state. Of fifteen others mentioned as likely to occur, over one-half have since been added.

In 1868 was published a "Catalogue of the Birds of New England," by Dr. Elliott Cones, in which nearly all the species previously attributed to Massachusetts were included. The Great Auk (Alca impennis) was here for the first time recognized as a former inhabitant of Massachusetts, and the Barn Owl (Strix pratincola) and the Varied Thrush (Turdus noevius) were added in the Appendix from notes furnished by the present writer.

${ }^{2}$ Squatarola helvetica was aceidentally omitted from the Springfleld list, though given in the classified list at the end of the paper; hence in my "summary" ( $p .97)$ " 296 " should stand 297. 
During the winter of 1869-70 I published additional "Notes on some of the Rarer Birds of Massachusetts" (Amer. Nat., III, Dec., 1869, Jan. and Feb., 1870), in which ninety-two species were formally referred to, and eight for the first time recorded as captured or observed within the state (exclusive of one included by error of identification, and four others perhaps not properly to be regarded as indigenous or naturally occurring species). Several species given in my previous list were now withdrawn. The number of species then stood nominally at three hundred and five, but in reality (or as judged by the standard I have adopted for my present list) two hundred and ninety-five.

Later in the same year appeared Mr. Maynard's excellent "Catalogue of the Birds of Eastern Massachusetts", (Naturalist's Guide, 1870, pp. 81-167), comprising nominally two hundred and ninety-nine species, but adding no new ones. Applying the same rules of exclusion that have been used in respect to the other before-mentioned lists the number becomes reduced to about two hundred and eighty-nine. Five or six were withdrawn as birds of Eastern Massachusetts, but otherwise the list includes all of the at that time authenticated indigenous birds of the state except four, known at that date as occurring only in the western part of the state.

Since 1870 about twenty-five species have been added, mainly through the investigations of Messrs. Brewster, Purdie, Deane, and Maynard, including three first described from birds taken within the state. No new separate enumeration of the birds of Massachusetts has, however, been since made, but in 1875 Dr. 'T. M. Brewer published a new "Catalogue of the Birds of New England" (Proc. Bost. Soc. Nat. Hist., XVII, July, 1875 , pp. 436-454), in which, of course, those of Massa- 
chusetts were included, embracing nearly all the additions made between the years 1870 and 1875 , but generally without giving the date of capture or place of record. Of this list of three hundred and thirty-six species twelve are cither explicitly or inferentially given as not found in Massachusetts; fourteen others are regarded in the following list as either purely nominal or as merely varietal forms of other species also occurring here; one is an introduced species, and another ("Thaumatias linnoei") I regard as improperly included; leaving three hundred and eight that may be regarded as birds of Massachusetts, though not of course always necessarily so implied by the phraseology of the list.

The following tabulated summary shows at a glance the number of species attributed to the state at different times since 1833, together with the number authentically recorded, the number still unconfirmed, and the number of merely nominal ones :-

\section{HISTORICAI, SUMMARY.}

Whole Syno. Unconffrmed or Fully Number number. nyins, not legitinitely authenticated. idded.

\begin{tabular}{|c|c|c|c|c|c|c|}
\hline \multirow{2}{*}{\multicolumn{2}{|c|}{ 1833, Emmons, }} & \multicolumn{4}{|c|}{ incluiled.s } & \multirow[b]{2}{*}{ - } \\
\hline & & 160 & 2 & 1 & 157 & \\
\hline 1837, & Brewer, ${ }^{4}$ & 205 & 5 & 3 & 197 & 40 \\
\hline 1839, & Peabody, & 284 & 13 & 20 & 251 & 54 \\
\hline 1856 , & Putnam, & 293 & 7 & 11 & $27 \check{5}$ & 24 \\
\hline 1864, & S:ımuels, & 269 & 3 & 5 & 261 & 一 \\
\hline 1864, & Allen, & 297 & 3 & 12 & 282 & 7 \\
\hline 1870 , & Allen, & 305 & 2 & 8 & 295 & 13 \\
\hline 1870, & Maynard, & 303 & 3 & 11 & 289 & - \\
\hline 1875 , & Brewer, ${ }^{5}$ & 322 & 3 & 11 & 308 & 13 \\
\hline 1878, & Allen, & 340 & - & $24^{6}$ & $316^{7}$ & 8 \\
\hline
\end{tabular}

${ }^{3}$ Enbracing, among others, varietal forms hero regarded as improperly accorded full specifie rank.

- Inferentially, through arditions to Dr. Emmons's list.

- Inferentially determined.

- Given as probably occurring, but not as yet fully confirmed.

$\checkmark$ Plus four extirpated $=320$. 


\section{Species of Authentic Occurrence within the State.}

INoTE.-The asterisk (*) at the left of a name indicates that the species is known to breed within the state. For the sake of brevity, the annotations are restricted to simply indication of season of occurrence and relative abundance, except in the case of the extrenely rure or accillental visitors, respecting which the record of captures is brought down from 1864 to January, 1878. Only the original notice, however, is cited. My former catalogue gives the record of rare captures down to $186 t$ (see also Cones's "Catalogue of the Birds of New England" in Proceedings Essex Institute, vi, pp. 253-314, for the early record), so that my former paper, and the present, form together a full record in this respect.]

*1. Turdus migratorius Linn. Roвrs. Abundant summer resident; a few remain cluring winter at favorable localities.

2. Turdus nævius Gmel. Varied Tirrusir. Accidental. As yet the only authentic record of its occurrence is its capture at Ipswich, in December, 1864 (Allen, Proc. Essex Inst., V, 1868, 312 ; Amer. Nat., III, Jan., 1870, 572; see further, on its supposed earlier occurrence in Massachusetts, Proc. Essex Inst., IV, 1864, 82).

*3. Turdus mustelinus Gmel. Wood Turusir. Common summer resident except in the higher portions of Berkshire County.

*4. Turdus pallasi Cab. Hиrmr Tmisusir. Spring and fall migrant, except in the mountainous portions of the state west of the Connecticut valley, where it is a common summer resiclent; occasionally breeds in other parts of the state.

5. Turdus swainsoni $C a b$. (=T. swainsoni et alicice auct.) Olive-BaCKED THuUsir. Common spring and autumn migrant; probably breeds in portions of Berkshire County.

*6. Turdus fuscescens Steph. Veery ; Wilson's Tirusir. Common summer resident.

*7. Mimus polyglottus Boie. Mockixg Bird. Rare summer visitant, occasionally breeding, particularly in the Connecticut Valley.

*8. Mimus carolinensis Gray. Cat Brid. Abundant summer resident.

*9. Harporhynchus rufus Cab. Brows Turusir. Abundant summer resident.

*10. Sialia sialis Hald. Brunbrnd. Abundant summer resident.

11. Regulus calendula Licht. RuBY-Crowned Kinglet. Abundant spring and summer visitant.

12. Regulus satrapa Licht. Golnen-cristrin Kinglut. Chiefly a winter visitant, occurring in variable abundance in different years, but usually more or less common. l'erhaps breeds in portions of Berkshire County, as it has been reported to do in the Catskills (Trippe, Am. Nat., VI, 47).

13. Polioptila cærulea Scl. Blue-Gray Gnat-Catcher. Accl- 
dental. One instance (Chatham, Nov. 18, 1877, Deane, Bull. Nutt. Orn. Club, III, Jan., 1878, 45). Several recent instances of its capture near Providence, R. I. (Purdie, Bull. Nutt. Orn. Club, II, Jan., 1877, 20; Merriam, Rev. Bds. Conn., 1877, 8.)

*14. Parus atricapillus Linn. Chrckadef. Common resident.

15. Parus hudsonicus Forst. Hudsonian Chickader. Accidental. (Concord, Oct. 30, 1870, Brewster, Am. Nat., VI, 306. Also given as a bird of the state by Peabody, Rep. Orn. Mass., 402.)

*16. Sitta carolinensis Gmel. White-Bellied Nuthatch. Rather common resident.

17. Sitta canadensis Linn. ReD-Bellied Nuthatch. Winter visitant. Not generally common. The doubtfully supposed instance of its breeding on the ground in Roxbury (May, 1877, recorded in Am. Nat., XI, 565), proves to have been a mistake, the eggs taken proving not to be those of that species.

*18. Certhia familiaris Linn. Brow. Creeper. Resident, but most numerous in spring, autumn and winter.

*19. Troglodytes aëdon Vieill. House Wrev. Rather common summer resident.

20. Troglodytes parvulus var. hyemalis Coues. Wriver Wrks. Winter visitant; not common. Perhaps breeds in the higher mountainous portions of Berkshire County. (T. Martin Trippe gives it as breeding in the Catskills, Am. Nat., VI, 47.)

*21. Cistothorus stellaris Cab. Short-Billed Marsi Wren. Locally common.

*22. Cistothorus palustris Baird. LoNg-Billed Marsi Wren. Common, like the preceding, at favorable localities.

The Carolina Wren (Thryothorus ludovicianus Bon.) has been reported as occurring in Roxbury, in the summer of 1876 , but no specimens were taken (Minot, Bull. Nutt. Orn. Club, I, Sept., 1876, 76; Land Birds and Game Birds of New England, 1877, 74).

23. Eromophila alpestris Boie. Shorl LarK; Horned LARK. Winter visitant, chiefly along the coast, where it is generally common and sometimes abundant.

24. Anthus ludovicianus Licht. Tithark; Brown Lark. Spring and autumn visitant, in small flocks.

*25. Mniotilta varia Vieill. Black-And-white Creeper. Common summer resident.

*26. Parula americana Bon. Blue-yellow-BaCked Warbler. Rather common summer resident.

*27. Helminthophaga ruficapilla Baird. Nashville Warbler. Common summer visitant.

28. Helminthophaga celata Baird. Orange-Crowned WarBLEr. Rare or accidental. Only three instances of its capture thus 
far on record. (Springfield, May 15, 1863, Allen, Proc. Essex Inst., IV, 1864, 60; Lynu, Jan. 1, 1875, Brewer, Proc. Bost. Soc. Nat. Hist., XVII, 439; Concord, Oct. 2, 1876, Brewster, Bull. Nutt. Orn. Club, I, Nov., 1876, 94. The only other New England records are Hollis, N. H., May 16, 1876, Fox, Forest and Stream, VI, 354; Isles of Shoals, Murdoch, Bull. Nutt. Orn. Club, III, Apr., 1878, -.)

29. Helminthophaga peregrina Cab. Texnessee Warblek. Rare.

*30. Helminthophaga chrysoptera Baird. Goldev-Winged Waibler. Summer resident. Not generally common.

31. Helminthophaga leucobronchialis Brezoster. WHrtETHROATED WarbLer. Rare. One instance of its capture in the state thus far on record. Taken at Newtonville, May 18, 18i0. (Brezoster, Amer. Sportsman, V, 33, Oct. 17, 1874 ; Bull. Nutt. Orn. Club, I, 1876, 1. Original type of the species.) Three other specimeus have thus far been recorded. (Trolter, Bull. Nutt. Ol'n. Club, II, 1877, 79; III, 1878, 79 ; Connecticut, Brewster, ibid, III, Apr., 1878, -.)

*32. Dendrœca æstiva Baird. Yellow Warbler; Summer YelLow Bird. Abundant summer resident.

*33. Dendrœca virens Baird. Black-throated Green Warbler. Common summer resident.

*34. Dendrœca cærulescens Baird. Black-throated Blue Warbirer. Spring and fall migrant. Has been observed in summer in different portions of the state, and has been found nesting in Connecticut (two instances, June, 1874, Jones, Bull. Nutt. Orn. Club, I, 1876, 11). Also reported breeding in the Catskills (Trippe, Am. Nat., VI, 47).

35. Dendrœca coronata Gray. Ylllow-rumped Warbler; Myrtle Bird. Abundant spring and autumn migrant. A few known to winter on Cape Cod. May breed in portions of Berkshire County.

36. Dendrœca auduboni Baird. Audubon's Warbler. Accidental. (Cambridge, Mass., Nov. 15, 1876, Frazar, Bull. Nutt. Orn. Club, II, 1877, 27.)

*37. Dendrœca blackburniæ Baird. Blackburnia Warbler. Common spring aud autumn visitant, some remaining through the summer.

38. Dendrœca striata Baird. Blick-Poll Warbler. Abundant spring and autumn migrant.

39. Dendrœca castanea Bairl. Bay-Breasted Warbler. Common spriug and autumn migrant, varying greatly in abundance in different years.

*40. Dendrœca pennsylvanica Baird. Chestnut-sided WarBLER. Common summer resident.

41. Dendrœca maculosa Baird. Black-AND-Yellow Wakbler. 
Common spring and autumn migrant. Has been observed a few times In summer, and may breed in the higher parts of Berkshire County.

42. Dendrœca tigrina Baird. Cape MaY Warblkr. Rather rare spring and autumu migrant.

*43. Dendrœca discolor Baird. Prairie Warbler. Common summer resident near the sea-bonrd; less common in the interior.

44. Dendrœea palmarum Baird. Yellow Red-poll Warbler. Abundant spring and autumn migrant; a few have beeu observed at favorable localities in winter.

*45 Dendrœca pinus Baird. Pine Warbler. Common summer resident.

*46. Siurus auricapillus Swain. Golden-crowned Wagtail; "Ovkn-BIisD." Abundant summer resident.

47. Siurus nævius Coues ( $S$. noveboracensis auct.). WATER Wagtail; "Water THrush." Rather common spring and autumn migrant.

48. Siurus motacilla Bon. Large-Billed Water Wagtail. Rare or accidental. One record of its eapture (Mount Tom, April 28, 1869, Allen, Am. Nat., III, 557). Was found breeding near Norwich, Conn., by Mr. Jirnest Ingersoll, in June, 1873 (Am. Nat., VIII, 238). (The nest and eggs found by Mr. Ingersoll are in Mus. Comp. Zoöl., Cambridge.) Mr. Merriam gives it as "not rale in Southern Connecticut, where it breeds regularly, and probably in considerable numbers" (Rev. Birds Conn., 1877, 20).

49. Oporornis agilis Baird. Connecricut Warbinr. Generally a rare spring ancl autumn migrant; sometimes abundant in autumn in the vicinity of Cambridge. Probably more common in other parts of the state in autumn than is generally supposed.

*50. Geothlypis trichas Cab. Maryland Yellow-throat. Abundant summer resident.

51. Geothlypis philadelphia Baird. Mourning Warbler. Rare spring and autumn migrant.

*52. Icteria virens Baird. Yellow-Breasted Chat. Rare summer resident. Several records of its nesting in the eastern part of the state.

53. Myiodioctes pusillus Bon. Green Black-Capped WarBLEk. Rather rare spring and autumn migrant.

54. Myiodioctes canadensis Aud. Canadian Warbi.er. Common spring and autumn migrant. Occasionally seen in summer, and probably breeds sparingly in Berkshire Connty.

*55. Setophaga ruticilla Swain. Revstart. Rather common summer resident.

*56. Pyranga rubra Vieill. Scarlet Tanager. Common sum. mer resident. 
57. Pyranga æstiva Vicill. Summer Redird. Accidental summer visitor. Sereral instances of its capture are on record. Mr. N. Vickary informs me that a specimen (hitherto unrecolded) was taken in Swampscot in June, 1866.

*58. Hirundo horreorum Barton. Bard Swallow. Common summer resident.

*59. Tachycineta bicolor Cab. White-Bellied Swallow. Common summer resident.

*60. Petrochelidon Iunifrons Cab. Eave Swallow; Cuifs Swallow. Common summer resident.

*61. Cotyle riparia Boie. Bank Swallow. Common summer resident.

*62. Progne purpurea Boie. Purple Martiv. Common summer resident.

63. Ampelis garrulus Linn. Bohmman Waxwixg. Accidental in winter. To the few previous records of its capture $I$ here add another, a female, taken by Mr. N. Vickary at Iıynn, Feb. 18, 1877.

*64. Ampelis cedrorum Raird. Cedar Bird; Cherry Bird. Common summer resident; frequently seen in winter in roving flocks, and at localities where it finds food.

*65. Vireo olivaceus Vieill. RED-EYed Vireo. Abundant summer resident.

66. Vireo philadelphicus Cass. Philadelphia Vireo. Very rare. Only one instance of its capture thus far recorded. (Cambridge, Sept., 7, 1875, Brewster, Bull. Nutt. Orn. Club, I, 1876, 19. For a record of its occurrence in New England prior to Sept., 1876, see Deane, Bull. Nutt. Orn. Club, I, 74; see further, Fox, ibid, II, 78.)

*67. Vireo gilvus Bon. Warblisg Vireo. Common summer resident.

*68. Vireo flavifrons Vieill. Yellow-turoated Vireo. Rather common summer resident.

*69. Vireo solitarius Vieill. Solitary Vireo; Blue-Headed VIreo. Common spring and autumn migrant; a few pass the summer here and breed.

*70. Vireo noveboracensis Bon. White-kyed Vireo. More or less common summer resident at certain localites.

71. Collurio borealis Baird. Butcher Bird; Great Northern SHRIKE. Rather common winter visitant.

72. Collurio ludovicianus Baird (C. ludovicianus et excubitoroides auct.). Loggeli-IIEAd Sinike. Accidental. Several recent records of its occurrence. West Newton, Oct. 21, 1872 (Purdie, Am. Nat., VII, 1873, 115; first authentic record for the state); Newtonville, 1874 (Maynard, Am. Sports., V, 313, Feb. 13, 1875). A specimen (now first recorded) was also takeu in Lynn, Nov., 1877, by Mr. N. Vickary. 
73. Pinicola enucleator Vieill. PINE Grosbeak. Irregular winter visitant, occurring sometimes in abundance, but generally not common.

*74. Carpodacus purpureus Gray. Purple Fincr. Rather common summer resident; a few probably remain at some localities during winter.

75. Loxia leucoptera Gmel. WhITE-WINGed Crossbill. Irregular winter visitant.

76. Loxia curvirostra var. americana Coues. Common CrossBILL. Irregular winter visitor, but a much more frequent and abundant visitor than the preceding species. A few often occur in summer.

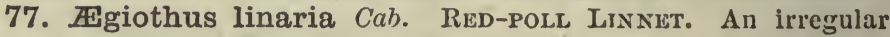
but often abundant winter visitor.

78. Linota flavirostris var. brewsteri Coues. Brewster's LiNNET. Rare or accidental. One specimen taken in Cambridge by Mr. W. Brewster (Ridgway, Am. Nat., VI, 433 ; see also Baird, Brewer and Ridgroay, Hist. Birds N. Amer., I, 1874, 501).

*79. Chrysomitris pinus Bon. PrNe Frnch. Chiefly spring and autumn migrant; occasionally remains through the winter, and has been known to occul in summer. Marked as breeding by Dr. Emmons.

*80. Chrysomitris tristis Bon. Yellow-BInd; Goldinch. Common throughout the year, but of gregarious and nomadic habits in winter.

81. Plectrophanes nivalis Meyer. Sxow Buxtrug. Regular and rather common winter visitant.

82. Plectrophanes lapponicus Selby. Lapland Loxgspur. Winter visitant, mainly near the coast; not common.

83. Plectrophanes ornatus Touns. Cinestnut-collared BuntIxG. Accidental. (Maguolia, near Gloucester, taken by Mr. C. W. Townsend, July 28, 1876, Brewer, Bull. Nutt. Orn. Club, II, 1877, 78.)

84. Passerculus princeps Maynard. Ipswicil Spariow. Rare winter visitant, occurring chiefly near the coast. IIas been met with from Prince Edward's Island and New Hampshire to Long Islaud.

*85. Passerculus savanna Bon. Savanna Sparrow. Abundant summer resident along the coast; much less common in the interior.

*86. Poccetes gramineus Baird. Grass Finch; BaY-Winged Sparrow. Abundant summer resident.

*87. Coturniculus passerińus Bon. Yellow-winged Sparrow. Common and even abundant summer resident at favorable localities, especially in the Connecticut Valley and near the sea coast.

*88. Coturniculus henslowi Bon. Hexslow's Bunting. Rare summer resident. 
*89. Ammodromus caudacutus Swain. Sinarp-tamed Fincri. More or less common in the salt marshes along the coast, especially in those of Charles River.

90. Ammodromus maritimus Swain. Sea-sidr Fincir. Rare or accidental in the sait marshes along the coast. Only one recent record of its capture in the state. (Nahant, Aug., 1877, taken by Mr. G. O. Welch, Brever, Bull. Nutt. Orn. Club, III, Jan., 1878, 48.) Mr. Merriam gives it as a common summer resident in the salt and brackish water marshes of Connecticut (Rev. Bds. Conn., 38).

91. Melospiza lincolni Baird. Lixcolx's Frxcir. Known only as a rare or casual visitor in spring. Mr. E. I. Shores considers it as not rare at Suffield, Conn., where he believes a few pairs breed (see Merriam's Rev. Bds. Conn., p. 38 ).

*92. Melospiza palustris Baird. Swamp Sparrow. A not very common summer resident, of rather local distribution.

*93. Melospiza melodia Baird. Soxg Sparrow. Abundant summer resident; a few sometimes remain in winter in sheltered localities.

*94. Junco hyemalis Scl. Sxow Brrd. Mainly a spring and autumn visitant; a few are sometimes observed in winter. Breeds abundantly in the more elevated parts of Berkshire County.

95. Junco oregonus Scl. Oregox Sxuw Bind. Accidental. (Watertown, March 25, 1874, Brewster, Bull. Nutt. Orn. Club, I, 1876, 19.)

96. Spizella monticola Baird. Tren Sparrow. Common winter visitunt.

*97. Spizella socialis Bon. Chirpixg Sparrow. Abundant summer resident.

*98. Spizella pusilla Bon. Freld Sparrow. Common summer resident.

99. Spizella pallida var. breweri Coues. Clay-Coloned SparRow. Accidental. (Watertown, Dec. 15, 1873, Brewoster, Am. Nat., VIII, 366.)

*100. Zonotrichia albicollis Bon. White-tnronted Spanrow. Abunclint spring and autumu migrant. Marked as brecding by Dr. Emmons.

101. Zonotrichia leucophrys Swain. Wuite-crowned Sparrow. Rather rare spring and autumn migrant.

102. Chondestes grammaca Bon. Lark Frxcir. Accidental. Two instances only of its occurrence recorded. (Gloucester, about 1845, Putnam, Proc. Essex Inst., I, 185̌G, 224; Newtonville, Nov. 25, 1877, I'urlie, Bull. Nutt. Orn. Club, III, Jan., 1878, 44.)

103. Passerella iliaca Swain. Fox-Coloned Spannow. Abundant spring and autumn migrant. 
104. Calamospiza bicolor Bon. Lank Buxtrixg. Accidental. One instance of its capture. (Lynn, Dec. 5, 1877, taken by Mr. N. Vickary. Allen, Bull. Nutt. Orn. Club, III, Jan., 1878, 48.)

*105. Euspiza americana Bon. Black-throated Bunting. Very rare summer resident.

*108. Goniaphea ludoviciana Bordich. 'Rose-Breasted GrosBEAK. Common summer resident.

*107. Cyanospiza cyanea Baird. Ixdigo Bird. Common summer resident.

108. Cardinalis virginiana Bon. Cardival; Redbind. Accidental. Very few instances of its occurrence recorded. (Its most northern record is IIalifax, N. S., January 31, 1871. Jones, Am. Nat., $\mathrm{V}, 176$.

*109. Pipilo erythrophthalmus Vieill. Chewink; Townee Buntrog. Abundant summer resident.

*110. Dolichonyx oryzivorus Suain. Bobolink; "SkUNK BL.ACKBnzD." Abundant summer resident.

*111. Molothrus ater Gray. Cowisind. Common summer resident.

*112. Agelæus phœniceus Vieill. Red-winged Blackbird. Cominon summer resident.

113. Xanthocephalus icterocephalus Baird. Y IRLOW-IIKADED BLackвци. Accidental. 'Two instances of its capture, the second here for the first time recorded. First identifled from the wings, tail, and foot of a specimen shot by Mr. Frank Sawyer in Watertown, Oct. 15, 1869. (Allen, Am. Nat., III, 1870, 636.) Mr. N. Vickary, of Lynn, informs me that two specimens were shot at Eastham, Sept. 10, 1877, by $\mathrm{Mr}$. Loud, of Salem, one of which is preserved.

*114. Sturnella magna Swain. Mradow Lark. Common summer resident; a few sometimes remain in winter.

*115. Icterus spurius Bon. Orcinand Onole. Rare summer resident. More common in the Connecticut Valley than elsewhere in the state.

*116. Icterus baltimore Daud. Baltimore Oriole. Abundant summer resident.

117. Scolecophagus ferrugineus Srain. Rusty Grackle. Rather common spring and autumn visitant.

*118. Quiscalus purpureus Licht. PurPle Grackle. Common summer resident.

119. Corvus corax Linn. Raven. Very rare. Very few recorded instances of its capture within the state. (A recent record is Williamstown [1876?]. Tenney, Am. Nat., XI, 243.)

*120. Corvus americanus Aud. Cosmon Crow. Common resident. 
*121. Cyanurus cristatus Swain. Blue JAY. Common throughout the year.

*122. Tyrannus carolinensis Baird. KrvgBird. Common summer resident.

123. Tyrannus dominicensis Rich. Gray Krngbird. Accidental. Taken in Lynn early in October, 1869. (Allen, Am. Nat., III, Feb., 1870, 645.)

*124. Myiarchus crinitus Cab. Great crested Flycatcher. Rare summer resident.

*125. Sayornis fuscus Baird. Pirgebe; Bridge Pewee. Common summer resident.

*126. Contopus borealis Baird. OLrve-sided Pewee. Rather uncomnon summer resident.

*127. Contopus virens Cab. Wood Pewee. Common summer resident.

*128. Empidonax minimus Baird. Least Pewee. Common summer resident.

*129. Empidonax trailli Baird. Traill's Flycatchifr. Chiefly a spring and autumn visitant; not common. A few remain in summer and breed.

130. Empidonax flaviventris Baird. Yellow-Bellied PewEeh. Not uncommon in spring and fall.

*131. Antrostomus vociferus Bon. Wuip-poor-wrL. Common summer resident.

*132. Chordiles virginianus Bon. NIGHT HAwK. Abundant summer resident.

*133. Chrtura pelasgia Steph. Chimsey Swift. Abundant suinmer resident.

*134. Trochilus colubris Linn. RuBY-THnonted Humming-BIRd. Common summer resident.

*135. Ceryle alcyon Boie. Belted Kingrisner. Common summer resident. Occasionally met with in winter.

*136. Coccygus erythrophthalmus Bon. BLACK-BiLled Cuckoo. Common summer resident.

*137. Coccygus americanus Bon. Yellow-Billed Cuckoo. Rather frequent summer resident. Somewhat irregularly dispersed, and very variable in respect to numbers in different years.

*138. Hylotomus pileatus Baird. Pileatrid Woodpecker. Nearly or quite extirpated from most parts of the state, but still more or less frequent in Berkshire County, and of occasional occurrence in other well wooded portions of the state.

*139. Picus villosus Linn. Hairy Woodpecker. A not common resident. More numerous in winter than in summer, when it is generally rare. 
*140. Picus pubescens Linn. Dowxy Woodpecker. Rather, common resident.

141. Picoides arcticus Gray. Black-Backed Woodpreker. Very rare winter visitant. A recent record of its capture in "Middlesex County, fall of 1871." (Purdie, Am. Nat., VII, 1873, 693.)

142. Picoides americanus Brehm. (P. hirsutus of most Massachusetts lists.) BANDED-BACKED WOODPECKer. Very rare or accidental winter visitant. Very few instances are on record of the capture of either species of this genus in the state. $P$. arcticus has been more frequently recorded than $P$. americanus. (See Allen, Am. Nat., III, 572.)

*143. Sphyrapicus varius Baird. Yellow-Beldied Woodpecker. Not very uncominou in spring and fall, and a few probably breed, more especially in Berkshire County. (Marked as breeding by Dr. Emmons.)

144. Centurus carolinus Bon. Red belimed Wooppecker. Accidental. Not to my knowledge yet taken in the state, but observed by me at Springfield, May 13, 1863, under circumstances that would render a mistaken identiflcation almost impossible (Proc. Essex Inst., IV, 53). It has since been taken by Mr. Shores within a few miles of this locality (at Suffeld, Conn., Merriam, Rev. Birds of Conn., 1877, 65).

"145. Melanerpes erythrocephalus Sicain. RED-IIEAded WondPECKer. Rare summer resident, occasionally breeding. Most frequently observed in fall, usually in immature plumage.

*146. Colaptes auratus Swain. GoLdeN-WiNged WoodPECKer. Abundant summer resident. Occasionally seen in winter.

147. Strix flammea Linn. Bars OwL. Very rare or accidental. Only two specimens as yet known to have been taken in the state,one at Springfield, May, 1868 (Allen, Proc. Essex Inst., VI, 1868, 312); the other at Lyun, in 1865 (Allen, Am. Nat., III, Feb., 1870, 646).

*148. Bubo virginianus Bon. Great Homsed Owl. A not uncommon-resident.

*149. Scops asio Bon. Motrled OwL. Common, resident.

*150. Otus vulgaris Flem. Loxg-Eared Owi. Not common, resident.

*151. Brachyotus palustris Bon. Short-Eared OwL. Rather common resident.

152. Syrnium cinereum Aud. Great Gray Owi. Accidental or very rare winter visitant. I have no record of its capture in the state since 1866 (Salem, Nov. 10, 1866, Allen, Am. Nat., IIf, Jan., $1870,570)$.

*153. Syrnium nebulosum Gray. Barred OWL. Rather common resident. 
*154. Nyctale acadica Bon. SaW-Twiet OwL; AcadinN OWf. Rather common and probably resident. (See Deane, Bull. Nutt. Orn. Club, .II, 84.)

155. Nyctale tengmalmi Bon. (N. richardsoni auct.) TexGMALMI'S OWL.. Rare wintel visitor. Recent records of its occurrence are: Lyun, 1863 (Allen, Am. Nat., III, Feb., 1870, 616); Cambridge, Dec., 18G5 (Maynard, Nat. Guide, 1870, 133).

156. Nyctea scandiaca Newt. Sxowy OwL. A more or less regular winter visitant. Vंery abundant during the winter of 1876-77. (See Deane, Bull. Nutt. Orn. Club, II, 9, 1877.)

157. Surnia ulula Bon. Hawk OwL. Very rare winter visitor in most parts of the state; probably of rather frequent occurrence in the more elevated parts of Berkshire County.. (For the record of its occurrence see Am. Nat., III, Dec., 1869, 569.)

158. Speotyto cunicularia var. hypogæa Coues. Burrowiva OwL. Accidental. Newburyport, May 4, 1875 (Deane, "Rod and Gun," VI, 97, May 15, 1875).

*159. Circus cyaneus var. hudsonius Schl. Marsn Hawk. Common summer resident.

160. Nauclerus furcatus Vig. Strallow-Tamled Hawk. Accidental. One record of its occurrence (to me a satisfactory one), but none of its capture (Whately, about 1868 , Allen, Am. Nat., III, Feb., $1870,645)$. Mr. Merriam gives it as "a rare straggler from the South," and cites two instances of its occurrence in that state (Rev. Birds Coun., 1877, 76).

*161. Accipiter fuscus Bon. Sharp-shinnted Hawk. Rather common snmmer resident.

*162. Accipiter cooperi Ron. Cooper's Hawk. Common summer resident; of occasional occurrence in winter.

163. Astur atricapillus Bon. Gosinawk. Rather freqnent winter visitant. Has been seen in summer, and perhaps occasionally breeds.

164. Falco gyrfalco Linn. Grrialcon. Of rare or accidental occurrence in winter.

164a. Falco gyrfalco var. labradora Ridg. Black Grrialcon. Accidental. Breed's Island, October, 18i6. (Cory, Bull. Nutt. Orn. Club, II, J:ın., 1877, 27.)

*165. Falco commủnis Linn. Duck Hawk. Rare resident; more common in winter than in summer and along the coast than in the interior.

166. Falco columbarius Linn. Prgeon Hawk. Rather rare, occurring chiefly in spring, fall, and winter.

*167. Falco sparverius Linn. Spanrow Hawk. More or less common resident; most numerous in spring and fall. 
*168. Buteo borealis Vieill. Red-tailed Buzzard. A rather common resident.

*169. Buteo lineatus Jard. Red-siout.dered Buzzard. Common resident.

170. Buteo swainsoni Bon. Swarsos's Buzzard. Accidental. Two instances of its capture thus far on record. (Salem, winter of 1871-72, Mus. Peabody Academy; Wayland, Sept. 12, 1876, Brewoster, Bull. Nutt. Orn. Club, III, Jan., 1878, 39.).

-171. Buteo pennsylvanicus Bon. Brosd-winged Buzzard. Rather rare summer resident.

172. Archibuteo lagopus Gray. Rovgit-liggrid Buzzard. Rather common winter visitant, but of somewhat local distribution.

*173. Pandion haliaëtus Sav. Fisn Hawk. Occasional summer visitant. Formerly bred in the state, but probably nests here very rairely, if at all, now.

174. Aquila chrysaëtus Linn. Golden EaGLE. Very rare winter visitant. Recent records of its capture are: Munson, Nov., 1864; Deerfield, Dec. 14, 1865; Westfield, three specimens, 1866 (Allen, Am. Nat., III, Dec., 1869). I have now to add Fairhaven, Nov. 21, 1873, shot by Mr. Nelson H. Stephens. The specimen was sent in the flesh by Captain Charles Bryant to the Museum of Comparative Zoölogy, where it is now preserved.

*175. Haliaëtus leucocephalus Sav. White-HEaded Eagie; Batd EAgLF. Rare resident.

176. Rhinogryphus aura Rilg. Turkey Vulture; "TurkeY Buzzard." Accidental. Two instances of its capture recorded, but none since 1864 .

177. Catharista atratus Gray. BLACK Vulture. Accidental. Quite a number of instances of its capture are on record. Recent ones are Hudson, 1868, where several specimens were scen (Allen, Nat., III, Feb., 18i0, 646). A recent record also for Maiue is Calais, 1869 (Boardman, Am. Nat., III, 498).

*178. Ectopistes migratorius Swain. Wild Pigeon. Irregular summer resident, not generally common.

*179. Zenædura carolinensis Bon. Carolina Dove; "MourNrivg Dove." Common summer resident.

180. Tetrao canadensis Linn. Spruce Partridge; Canada Grouse. Accidental. Only two recorded instances of its capture, which are Gloncester, 1851; Roxbury, about 1865 (Allen, Am. Nat., III, Feb., 1870, 636).

*181. Cupidonia cupido Baird. Pinnated Grouse; Prairie Hex. Formerly common in portions of the state, but long since extirpated from all portions except Martha's Vineyard, where a few are said to still exist. 
*182. Bonasa umbellus Steph. Rufred Grouse; "Partridge." Common resident.

*183. Ortyx virginianus Bon. Quall; Bon-wirte. More or less common resident in most parts of the state.

184. Squaftarola helvetica Cuv. Black-Bellied Plover. Generally more or less common during the spring and fall.

185. Charadrius virginicus Borck. Guldex Plover. Common spring and autumu inigrant.

*188. Aॄgialites vocifera Cass. Killddeer Plover. A not common summer resident.

187. 开gialites semipalmata Cab. Semipalmated Plover; "RrNG-NkCK." Abundant spring and autumn visitant.

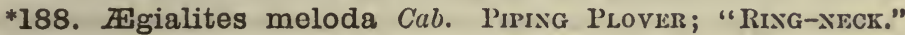
Common summer resident along the coast.

189. Hæmatopus palliatus Temm. Oyster-C.ATcher. Accidental in summer.

190. Strepsilas interpres $\mathrm{Ill}$. Tunssroxe. Rather common spring and autumn visitant.

191. Himantopus nigricollis Vieill. Black-Necired Strit. Accidental. Mr. Milynard gives it, ou the authority of "gunuers and others," as "occasionally seen along the sandy beaches" (Nat. Guide, 1870, 143). Mr. Boardman saw, some years since, two specimens in a Boston market, which he was assured were taken in this state (Allen, Am. Nat.. III, Feb., 1870, 638).

192. Steganopus wilsoni Coucs. Wilsox's Piralarope. Accidental. No recent record of its capture.

193. Lobipes hyperboreus Cuv. Nortiern Phalarope. Known only as a rare spring and autumn migrant.

194. Phalaropus fulicarius Bon. Red Phalarope. Not common spring and autumn migrant.

*195. Philohela minor Gray. American Woodcock. Common summer resident.

*196. Gallinago wilsoni Bon. Wilsox's Sxipe. Common during migrations and a rather rare summer resident. A few pass the winter at favorable localities.

197. Macrorhamphus griseus Leach. (M. griseus et scolopaceus auct.) RED-Bieasted SNIPE. Rather common spring and autumn migrant.

198. Micropalama himantopus Bairl. Stilt Sandpiperr. Rare, occurring chiefly during the autumnal migration. Several recent instances of its capture within the state.

199. Ereunetes pusillus Cass. Simipalmated Sandpiper. Abundant during its migrations; a few sometimes met with in summer. 
200. Tringa minutilla Vieill. Least SaxdPIPER. Abundant during its migrations.

201. Tringa bairdi Coues. Bamb's SANDPiper. Accidental. Taken by Mr. H. W. Hensliaw on Long Island, Boston Harbor, Aug. 27, 1870 (Brevoster, Am. Nat., VI, May, 1872, 306).

202. Tringa fuscicollis Vieill. (T. bonapartei et schinzi auct.) White-rumped SANinipier. Common spring and fall migrant.

203. Tringa maculata Vieill. Pectoral Sandpiper. Common during its nigrations.

204. Tringa maritima Brann. Punple Saxdpiper. Rather rare spring and autumn visitant; a few sometimes remain in winter.

205. Tringa alpina var. americana Cass. American Dundin. Abundant spring and autumn visitant; a few sometimes remain in summer.

208. Tringa subarquata Gald. Curcew Saxdpiper. Rare or accidental in spring and fall. Accorling to Dr. Brewer, there was no authenticated instance of its occurrence in New England on record prior to 1875 , wlien he announced the capture of a specimen "recently taken" in Ipswich (Proc. Bost. Soc. Nat. Hist., XVII, Nov., 1875, 446). Mr. E. A. Samuels, however, refers to its having been shot on Cape Ann in 1865 (Orn. and Oöl. New Eng., 1868, 447). Mr. Brewster has since recorded its capture in East Boston, early in May, 1866 (Bull. Nuitt. Orn. Club, July, 1876, 51).

207. Tringa canutus Linn. KNot; Red-Breasted Sandpiper. Common spring and autumn visitant.

208. Calidris arenaria Ill. SANDerLixg. Abundant spring and autumn migrant; stragglers sometimes remain in summer.

209. Limosa fedoa Ord. Great Malibled Godwit. Rare spring and autumn visitant.

210. Limosa hudsonica Svainson. Hudsoniax Godwrt. Rare during its migrations.

*211. Totanus semipalmatus Gmel. WILLET. Rare summer resident, sometimes breeding.

212. Totanus melanoleucus Gmel. Greater Yellow-LEgs; Greater Trlltale. Common spring and autumn migrant, and a few linger in summer.

213. Totanus flavipes Gmel. Lesser Yellow-thgs. Common spring and autumu visitant; rare in summer.

214. Totanus solitarius Wils. Solitary Saxppiper. Common in spring and fall; stragglers sometimes remain in summer.

*215. Tringoides macularius Gray. Spotted Saxdpiper. Common summer resident.

216. Philomachus pugnax Gray. RurF. Accidental. The only record of its occurrence appears to be "Newburyport marshes, May 28, 1871" (Bretcster, Am. Nat., VI, May, 1872, 306). 
*217. Actiturus bartramius Bon. Upland Plover: Common summer resident.

218. Tryngites rufescens $C a b$. Buff-Breasted Sandpiper. Rather uncommon spring and autumn visitant.

219. Numenius longirostris Wils. Loxg-BILled Cunlew. A not very common spring and autumn visitant.

220. Numenius hudsonicus Lath. Hudsonian CuneEw. Rare spring and fall migrant.

221. Numenius borealis Lath. Esqumaux CunLEw. Rather common spring and autumn migrant.

222. Falcinellus igneus Gray. (Ibis ordi auct.) Grossy IBIs. Accidental. Several records of its occurrence, but only one recent (Nantucket, Sept., 1869, Allen, Am. Nat., III, Feb., 1870, 637).

*223. Ardea herodias Linn. Great Blue Heron. A not common summer resiclent.

224. Ardea egretta Gm. Great Winte Egret. Accidental. Several comparatively recent instances of its capture have been recorded. (IIudson, Ashland, and Lynn, Allen, Am. Nat., III, Feb., 1870, 637; Westford, 1873, Purdie, Aın. Nat., VII, 693.)

225. Ardea candidissima Jacq. Litrue Whitr Egret. Accidental. There are fewer recorded instances of the occurrence of this species than the preceding, and none recent.

226. Ardea cærulea Linn. Little Blue Heron. Accidental. No recent record of its occurrence.

*227. Ardea virescens Linn. Green Heron. Common summer resident.

*228. Nyctiardea grisea var. nævia Allen. Nignt Heron. Common summer resident. Stragglers have been observed at Cambridge in winter.

229. Nyctiardea violacea Sxain. Yellow-Crowned Nignt Heros. Accidental. One record (Lymu, Oct., 1862, Allen, Am. Nat., III, Feb.. 1870, 637).

*230. Botaurus minor Bon. Birters. Common summer resident.

*231. Ardetta exilis Gray. Least Bittern. Not generally common, but rather frequent at some localities.

232. Rallus longirostris Bodd. Clapper RaIL; Salt-water Mansir His. Accidental. One instance (Boston Harbor, May 4, 1875, Purdic, Bull. Nutt. Orn. Club, II, Jan., 1877, 22). IIas been repeatedly taken in Connecticut (Merriam, Rev. Birds Conn., 1877, 115).

233. Rallus elegans Aud. Kixg Rall; Fresulwater Hen. Accidental. One instauce (Nahnnt, Nov. 21, 18i5, Purdie, Bull. Nutt. Orn. Club, II, Jan., 1877, 22). A rare summer resident in Southern Connecticut (Merriam, Rev. Birds C'onn., 115). 
*234. Rallus virginianus Linn. Virgixia RaIL. Common summer resident.

*235. Porzana carolina Vieill. Carolrsa RaIl; Sora. Common summer resident.

*236. Porzana noveboracensis Cass. Yellow RaIL. Very rare summer visitant.

237. Porzana jamaicensis Cass. Black RaIL. Very rare, perhaps accidental, summer visitant. One instance only of its capture in Massachusetts recorded (Clark's Isl., Plymnuth Harbor, Aug., 1869, Purdie, Bull. Nutt. Orn. Club, II, Jan., 1877, 22). As yet only two records of its capture in Conuecticut (see Merriam, Rev. Birds Conn., $1877,119)$.

*238. Gallinula galeata Bon. Fr.orina Gallixulx. Rare summer visitant, doubtless occasionally breeding (see Allen, Am. Nat., III, Feb., 1870, 639). Given by Merriam as a "rather common summer resident" of Connecticut (Rev. Birds Conn., 19).

239. Porphyrio martinica Temm. Punple Gallinule. Accidental. A recent record of its occurrence is Rockport, Apr. 12, 1875 (Whitman, Am. Nat., IX, Oct., 1875, 674). More easterly recent records are Calais, Me., Boardman, Am. Nat., III, 498; Halifax, January 30, 1870, Jones, Am. Nat., IV, 253).

*240. Fulica americana Gmel. Cоот. Rare summer resident; more numerous in fall and spring.

241. Cygnus americanus Sharpl. Wusthing Swan. Given by Dr. Brewer as "rare, migratory," in Massachusetts (Proc. Bost. Soc. Nat. Hist., XVII, 1875, 447), but I can point to no recent record of its actual capture. In early times (first half of the seventeenth century and later) this species (and probably also the Trumpeter Swan, C. buccinator) was common (see Bull. Nutt. Orn. Club, I, Sept., 1876, 58). According to Mr. Merrlam, swans presumed to be C. americanus have recently been taken in Connecticut (Rev. Birds Conn., 1Si7, 120).

242. Anser hyperboreus Pall. Sxow Goose. Rare winter visitant.

243. Anser albifrons var. gambeli Coues. WIItE- Frontud Goose. Rare spring and fall migrant. Some years since I found specimens in the Boston markets I had reason to believe were killed in the state. Dr. Brewer says it was more common thirty and forty years ago than now, as was the case with many of our other ducks and geese (Bull. Nutt. O'n. Club, II, Apr., 1877, 46).

244. Branta bernicla Scop. Brant Goose; Black Brant. Not uncommon spring and autumn migrant.

244a. Branta bernicla "var. nigricans" Coues. With the preceding.

245. Branta canadensis Gray. Canada Goose. Common spring and autumn visitant; probably formerly a summer resident. 
245a. Branta canadensis "var. hutchinsi" Coues. Hutchiss" Goosk. Less common than var. canadensis. Formerly more abundant than at present (Brewer, Bull. Nutt. Orn. Club, II, Apr., 1877, 46).

246. Anas boschas Linn. Mallard. Rare in spring and fall.

*247. Anas obscura Gmel. BLACK Duck. Abundant winter resident and rare in summer; doubtless formerly regularly resident the whole year.

248. Dafla acuta Jenyns. Pin-TaIL DucK. Rare winter visitant.

249. Chaulelasmus streperus Gray. Gadwall; Gray Duck. Rather rare spring and autumn visitant.

250. Mareca americana Sleph. BaldPate; AMerican WidgEov. Spring and autumn visitant.

251. Querquedula discors Steph. Blue-Winged Teal. Rather common spring and autumn migrant; formerly doubtless a summer resident.

252. Querquedula carolinensis Steph. Green-Winged Teat. Common spring and autumn migrant.

253. Spatula clypeata Boie. Shoveller. Rare spring and autumn visitant. It was formerly, judging from its present breeding range in the interior, a frequent summer resident.

*254. Aix sponsa Boie. Wood DucK; Summer Duck. Common summer resident.

255. Fuligula marila Steph. Greater Blacknead; Scaur Duck. Not common spring and autumn visitant, some remaining in winter.

255a. Fuligula marila var. affinis Allen. Lisser BLACKuead. Not common in spring and fall.

256. Fuligula collaris Bon. RixG-Necked Duck. Rare spring and autumn migrant.

257. Fuligula ferina var. americana Coues. Reduead; PochARD. Rare spring and antumn migraut.

258. Fuligula vallisneria Steph. Casvass-Back. Very rare spring and autumn visitant.

259. Bucephala clangula Gray. GoldeN-eyed DucK; WursTLk1. Common winter resident.

260. Bucephala islandica Baird. Barrow's GoLDFN-EYE. Rare winter visitant. Only recently added to the fauna of the state on record of its actual capture (Brevoster, Am. Nat., VI, May, 1872, 306).

261. Bucephala albeola Baird. Buffle-Inead; Butter-Ball. Common winter visitant.

262. Harelda glacialis Leach. LoNG-TAILED DUCK; OLD WIFE; Ord Squaw. Common winter visitant.

263. Histrionicus torquatus Bon. Harlequix Duck. Rare 
winter visitant. Formerly, like most of the ducks, more common than now (Breucer, Bull. Nutt. Oin. Club, II, Apr., 1877, 46).

264. Camptolæmus labradorius Gray. Laвiador: Duck. Formerly a rare winter visitant; probably now nearly extinct.

265. Somateria mollissima Leach. Entr Duck. Common spring and autumn visitant, some remaining in winter.

266. Somateria spectabilis Leach. Kixg Eıder. Rare winter visitant.

267. Fdemia americana Sroain. Scotrr. Abundant in spring and fall and common in winter.

268. CFdemia fusca Swain. Velvet Scoter; Whith-Winged Coor. Common winter visitant.

269. Edemia perspicillata Fleming. SurF Duck. Common winter visitant.

270. Erismatura rubida Bon. RudDy Duck. Rather common winter visitant, but most numerous in fall and spring.

271. Mergus merganser Linn. Goosander; Mrrasser. Common winter visitant, but most numerous in fall and spring.

272. Mergus serrator Linn. Red-Bmeasted Meigaxser. Abundant in spring and fall, many remaining in winter.

273. Mergus cucullatus Linn. Hooded Murgasser. Rather common spring and autumn visitant, many remaining In winter, and perhaps in summer.

274. Sula bassana Linn. Gaxxet; Solas Goose. Common winter visitant.

275. Pelecanus trachyrhynchus Lath. Winte Pilican. Now accidental; formerly common (Allen, Bull. Nutt. Orn. Club, I, Sept., $1876,60)$. The only recent correct record of its capture appears to be North Scituate, Oct. 6, 1876 (Purlie, Bull. Nutt. Orn. Clıb, II, Jan., 1877, 22). The specimens reported by me (Am. Nat., III, Feb., 1870, 640) as taken at Ipswich and Nantucket were found later to be $P$. fuscus. (See remarks under $P$. fuscus.)

276. Pelecanus fuscus Linn. Brow Pricas. Accidental. Ipswich (Maynard, Nat. Guide, 1870, 149; erroneously noticed by me under the head of the preceding species in Am. Nat., III, 640). Nantucket (Allen, Am. Nat., III, Feb., 18i0, 640, but wrongly given as $P$. erythrorhynchus). Corrected in a note added to last page of author's extras, in which it is stated that "from information just received there is every reason for believing that this flock" of White Pelicans, mentioned on page 40 (of extras) as having visited Nantucket Island, "were Brown Pelicans."

277. Graculus carbo Gray. Common Cormorant. Common winter resident.

278. Graculus dilophus Gray. Double-Crested Conmonast. Not uncommon in wiuter. 
279. Stercorarius pomatorhinus Vieill. Ponamise JAEGER; Pomarixe Skua. A not common winter visitant.

280. Stercorarius parasiticus Cones. (S. crepidatus Saund.) Richardson's SkUa; Parasitic Jazger. Along the coast in winter; not common.

281. Stercorarius buffoni Cones. (S. parasiticus Saund.) BuFrov's SKuA. Rare on the coast in winter.

282. Larus glaucus Brünn. Glaucous Gull. Rare winter visitant.

283. Larus leucopterus Fabr. Whrte-Wisaed GulL. Rare winter visitant.

284. Larus marinus Linn. Great Black-Backed Gull. Common winter visitant.

285. Larus argentatus Linn. Hernixg Gull. Abundant winter visitant; a few remain along the coast in summer, where formerly they probably bred.

286. Larus delawarensis Ord. RiNG-BILled GulL. Rather uncommon on the coast in winter.

287. Larus tridactylus Linn. Kittrwake GulL. Common winter visitant.

*288. Larus atricilla Linn. LaUGirivg GUL.L. Formerly a not uncommon summer visitant; now nearly extirpated from our coast.

289. Larus philadelphia Ord. Boxaparte's Gull. Common winter visitint, but more numerous in fall and spring.

290. Xema sabinei Bon. FonKen-Tailed Gul.. Accidental. The only record is Boston Harbor, Sept. 27, 1874 (Brercster, Am. Sportsman, V, 18i5, 370).

291. Sterna anglica Mont. (S. aranea auct.) Gull-billed Trrs. Accidental. A recent record is Ipswich, Sept., 1871 (Brewster, Am. Nat., VI, May, 1872, 306).

292. Sterna caspia Pallas. Caspinn Tern. Rare or accidental in winter.

293. Sterna regia Gamb. Royal Tens. Accidental. Two specimens taken by Messis. Maynard and Brewster on Nantucket Island, July 1, 1874 (Am. Sports., V, 249, Jan. 16, 18ið).

294. Sterna cantiaca Gmel. (S. acuflavida auct.) SANDwicr Tens. Aecidental. One record only, Chatham, August, 1865 (Allen, Amer. Nat., III, Feb., 1870, 6t4).

*295. Sterna hirundo Linn. Commox Tern. Abundant summer resident along the coast.

296. Sterna forsteri Nutt. (S. havelli auct.) Fonster's Ters. Rare or accidentitl. Ipswich, Sept., $18 \pi_{0}$ (Bretcster, Am. Nat., VI, May, 1872, 306; coast, "two or three" specimeus, 1873, Purlie, Am. Nat., V1I, 6!3) 
*297. Sterna macrura Nord. ARctic Tern. Abundant summer resident along the coast.

The form described as Sterna portlandica by Mr. Ridgway (Amer. Nat., VIII, 1874, 433), and since referred to S. macrura by Brewster (Ann. Lyc. Nat. Hist. N. Y., XI, 1875, 201) and Saunders (Proc. Zool. Soc., Lond., 1876, 650) has been taken on Muskeget Island (Brewster, Am. Sports., V, 249, Jan. 16, 1875).

*298. Sterna dougalli Munt. (S. paradisea auct.) Roseate Turs. Common along the coast in summer.

*299. Sterna superciliaris var. antillarum Coues. Least Ters. Coinmon along the coast in summer.

300. Sterna fuliginosa Gmel. Sooty Trrn. Accidental. Two recent records of its capture in Massachusetts,-Lawrence, Oct. 29, 1876 (Deane, Bull. Nutt. Orn. Club, II, Jan., 1877, 27); Williamstown, Sept., 1876 (Tenney, Am. Nat., XI, 1877, 243). Also several times taken recently in Connecticut and Rhode Island,-Saybrook, Conn., sumincr of 1876 (Purdie, Bull. Nutt. Orn. Club, II, Jan., 1877, 22; see also Merriam, Rev. Birds Conn., 1877, 134). From these records it appears that six specimens were taken in Connecticut, one in lhode Island, and two in Massachusetts, during 1876, mostly in September.

301. Hydrochelidon lariformis Coues. Shont-tailed Tern; BLACK Ters. Aecidental, or very rare. Ipswich, taken by Mr. C. J. Maynard (Allen, Am. Nat., III, Feb., 18ī0, 6t4).

302. Cymochorea leucorrhoa Coues. Leacir's Petrel. Common winter visitant along the coast.

303. Oceanites oceanica Coucs. Wilsox's Petrei. Common off the coast.

304. Puffinus major Fabr. Greater Shearwater. Common off the coast, especially in winter.

305. Puffinus fuliginosus Strick. Sooty Sneanwaten More or less common off the coast, especially in winter.

*306. Colymbus torquatus Brünn. LooN; Grest Nortiens Divis. More or less frequent resident.

307. Colymbus septentrionalis Linn. ReD-turoated Diver. Common winter visitant along the coast; rare in the interior; most numerous in autumn and spring.

308. Podiceps cornutus Gmel. Hornen Grebe. Chiefly a winter visitunt, but not common; a few remain in summer.

309. Podiceps griseigena var. holbolli Coues. RED-NECKED Gribe. Cliiefly a winter visitant; not common. Sometimes met with in summer.

*310. Podilymbus podiceps Lawr. Pied-BiLled Grebt. Rather rare resideut; more common in spring and fall than at other seasons.

311. Utamania torda Leach. Razor-BILled AUK. Not uncommon winter visitant along the coast. 


\section{1}

312. Fratercula arctica Steph. Arctic Puffin; Sea Parrot. Not uncommon winter visitant.

313. Mergulus alle Vieill. Dovekie; Sea Dove. Irregular and generally rare winter visitant along the coast; occasionally common.

314. Uria grylle Brünn. BLack Guillamot. Rather common winter visitant.

315. Lomvia troile Brandt. (L. troile et ringvia auct.) Cоммом Guillemor; Murke. Common winter visitant.

316. Lomvia arra Coues. (Cataractes lonvia Bryant.) TmcKBilled Guillemot. Common winter visitant along the coast. .

\section{Extirpated Species.}

1. Meleagris gallopavo var. occidentalis Allen. WILD TurKEY. Well known to have been a common species in southern New England for a long time subsequent to the first settlement of this part of the country (sce Bull. Nutt. Orn. Club, I, Sept., 1876, 55), but long since ceased to exist here in a wild state. Considered as nearly extinct by Emmons in 1833, but said by Hitclicock to be at that time "frequently met with on Mount Ilolyoke" (IRep. on Geol. Mass., etc., $1833,549)$.

2. Grus canadensis Temmi. Saxdhill Crane; Brown Crane. Unquestionably more or less abundant two hundred years ago (see Bull. Nutt. Orn. Club, I, Sept., 1876, 58), but there is no recent record of its occurrence.

3. Grus americanus Ord. Whoopisg Crane; White Crane. This species was given by Emmons in 1833 as a rare but regular visitant, but there is no later record of its occurrence. It unquestionably occurred here at the time of the first settlement of the cauntry, in common witl the preceding species:

4. Alca impennis Linn. Great Auk. The former existence of this species in Massachusetts is attested by the occurrence of its bones in the Indian shell heaps of the coast, particularly at Ipswich, and there are also unquestionable allusions to its presence on Cape Cod at the time the coast was explored by Gosnold in 1602 (see Bull. Nutt. Orn. Club, I, Sept., 1876, 59).

Other species that are virtually extirpated, although retained in the preceding list, are the Prairie Hen (Cupidonia cupido), supposed to be now restricted to Martha's Vincyard, where only a few, if indeed any, representatives of this formerly rather common species still exist (see anteà, p. 22); the Whisılling Swan (Cygnus anericanus), now only a rare straggler, and probably also the Trumpeter Swan.(Cygnus buccinator). To these may probably be added the Labrador or l'ied Duck (Camplolcemus labradurius), respecting which see Rowley, Orn. Miscel., pt. VI, pp. 205-223, 18ī; also Bull. Nutt. Orn. Club, III, Apr., 1878. 


\section{Species of probable occurrence.}

Of the following list of twenty-four species, the greater part have been included in various former lists of the bircls of Massaclusetts, but generally on inferential or hearsay evidence, or by erroneous identifications. Six have actually been taken within the last three or four years by Mr. E. I. Shores, within a few miles of the southern boundary of the state (near my old collecting ground at Springfield). Others, from their known general range, must evidently occur at rare intervals, and I confidently expect that within the next ten years at least seven-cighths, and probably nine-tenths, of them will be added to the list of those included from having been actually taken within the state. At least one-half of them have already been obtained in adjoining states at points not far from the Massachusetts line.

1. Saxicola cnantha Bech. Stoxeciut. Has been taken in Labrador, at Quebec, Canada, and on Loug Island, and is of frequent occurrence in the Bermudas.

2. Iophophanes bicolor Bon. Crrsted Trmuouse. Northern New Jersey; Long Island; New London, Conn. (one instance, Merriam, Rev. Birds Conn., 1877, 9); New Haven, Conn. (Linsley); New Hampshire.

3. Protonotaria citrea Baird. Protmoxotary Warmen. Of accidental occurrence in eastern Maine and New Brunswick (Brever, Proc. Bost. Soc. Nat. Hist., XVII, 439, on the authority of MIr. Boardman), and being a southern species may be looked for as of casual occurrence in Massachusetts.

4. Helmitherus vermivorus Bon. Worm-eatisg Warblẹr. IIas been taken in Suffield, Conn., on the southern boundary of Massachusetts, and is a rather common summer resident in portions of Southern Commecticut (Purdie, Bull. Nutt. Orn. Club, II, Jan., 1877, 21 ; Am. Nat., VII, 1873, 692).

5. Helminthophaga pinus Baird. Brue-Wivged Yellow WarBLER. "A summer resident in southern Connecticut and in the Connecticut Valley," where it breeds (Merriam, liev. Birls Conn., 14).

6. Dendrœca cærulea Bairl. CAsullix IVARblir. Has been taken as far north as Suffield, Comm., on the southern boundary of the state (Purdie, Bull. Nutt. Orn. Club, II, 1877, 22).

7. Oporornis formosa Baird. Kextucky IVArbler. Was taken by Mr. L. I. Shores in Suflield, Conn., Ang. 16, 1876,-the only record for New England (Merriam, Rev. Birds Conn., 1877, 22).

8. Myiodioctes mitrata Aud. Hooded Warulkr. Rare summer resident in southern Connecticut (Merriani). Has been taken in Suflield, Conn., by Mr. E. I. Shores, July 8, 187 (Purdie, Bull. Nutt. Orn. Club, II, 1877, 21). 
9. Stelgidopteryx serripennis Baird. Rovgh-WINGED SWALLow. Taken at Suffield, Conn., by Mr. E. I. Shores, June 6, 1874 (Purdie, Bull. Nutt. Orn. Club, II, Jan , 1877, 21), its only New England record. It has been found, however, breeding at West Point, New York (Mearns, Bull. Nutt. Orn. Club, III, Apr., 1878, -), and will doubtless soon be added to the fauna of Massachusetts.

10. Goniaphea cærulea Gray. Blue Grosbeak. This southern specles having been taken at Grand Menan and Calais, Maine (Boardman, Proc. Bost. Soc. Nat. Hist., IX, 1862, 127) is surely to be added, sooner or later, to the list of Massachusetts birds. Its occurrence is a priori far more probable than that of many species that have been found here.

11. Perisoreus canadensis Bon. Canada JaY. This species occurs doubtless in Berkshire County as an occasional winter visitor.

12. Tyrannus verticalis Say. Arkansas Flycatcher. This species has been taken at Elliot, Maine (Bryant, Proc. Bost. Soc. Nat. Hist., X, 1865, 96; Purdie, Bull. Nutt. Orn. Club, I, Sept., 1876, 73), and is as likely to occur in this state as many western and southern species that have already been taken here.

13. Corvus ossifragus Wils. Fisir Crow. Probably rare or accidental. Although there is as yet no record of its capture within the state, Mr. W. Brewster, who is familiar with the species, observed a single individual in Cambridge, March 16, 1875 (Brewster, Bull. Nutt. Orn. Club, I, 19). Its recent capture at West Point, N. Y., and on Long Island, tends to confirm its reported occurrence in Connecticut by Linsley (Am. Jour. Sci. and Arts, XLIV, 1843, 260) and render it almost certain that stragglers will soon be takeu here. It is so easily confounded with the Common Crow, even when in hand, by ordinary observers, that it may for this reason have been heretofore overlooked.

14. Empidonax acadicus Baird. Acadian Flycatcher. Not known to have been taken in the state, but it has been obtained by Mr. E. I. Shores in Suffield, Conn., within ten miles of my old collecting ground at Springfield, Mr. Shores's specimen having been identified as $E$. acadicus by no less an authority than Mr. Robert Ridgway (Merriam, Rev. Birds Conn., 1877, 58). This places the species beyond question in the list of New England birds (see Brever, Proc. Bost. Soc. Nat. Hist., XVII, 1875, 452). I recorded this bird in 1864 as occurring at Springfield (Proc. Essex Inst., IV, 54), but have since become convinced that I mistook for it E. trailli.

15. Aॄgialites wilsonia Cass. Wilson's Plover. Its reported occurrence in the state rest on not wholly satisfactory authority (see Brewer, Proc. Bost. Soc. Nat. Hist., XVII, 1875, 452). There appears to be no recent well-authenticated instance of its occurrence north of Long Island. 
16. Scolopax rusticola Linn. European Woodcock. The occasional capture of this European species on the Atlantic coast, from Maine to Virginia (Loudon County, Nov., 1873, Coues, Am. Nat., X, 372 ), seems to render it probable that it will eventually be taken in this state.

17. Recurvirostra americana Gmel. Avoskt. As this species has been taken in one instance at Point Lepreanx, New Brunswick (not Calais, Me., as generally supposed; see Brever, Proc. Bost. Soc. Nat. Hist., XVII, 1875, 452), and near Saybrook, Conn. (Merriam, Rev. Birds Conn., 1877, 103), it may be fairly looked for as an accidental visitor.

18. Cygnus buccinator Rich. Trumpetre Swan. Recently reported by Mr. Merriam (Rev. Birds Conn., 1870, 120) as probably occurring in the vicinity of East Windsor Hill, Conn. (within fifteen miles of the Massachusetts line). In all probability it was common here two hundred years ago and may still be looked for as a straggler.

19. Anser cærulescens Pallas. Buue Goose. May be an accidental visitor, but according to Dr. Brewer (Proc. Bost. Soc. Nat. Hist., XVII, 1875, 452) there is no record of its actual occurrence in New England.

20. Branta leucopsis Boie. Barvacle Goose. As this accidental visitor has been taken in southern Labrador, Maine, on Long Island, and in North Carolina, and more than the "eight escaped birds" have been accounted for, it seems reasonable to include this species among those of probable occurrence in Massachusetts. On the occurrence of this species on the Atlintic coast of North America see Baird (Am. Nat., II, March, 1868, 39), Brewer (Proc. Bust. Soc. Nat. Hist., XVII, 1875, 452), Lawrence (A 1 . Nat., V, March, 1870, 10), and Lawrence and Dęne (Bull. Nutt. Orn. Club, II, Jan., 1877, 18). I understand specimens have recently been taken near Portland, Maine. It has been repeatedly attributed to Massachusetts, but probably on insufficient evidence. (See Allen, Proc. Essex Inst., IV, 1864, 88; Coues, Proc. Essex Inst., VI, 1868, 298.)

21. Mareca penelope Bon. Kunopenn Widgeon. This species likewise lacks contirmation as a bird of Massachusetts, or even of N ew England, although it has been taken on Long Island, and at various points in North America. It is of course to be looked for here.

22. Querquedula crecca Steph. Europlan Teal. The specimen recorded by Dr. Bryant (Proc. Bost. Soc. Nat. Hist., V, 1855, 195) as taken in this state Dr. Brewer says was actually taken in North Carolina and not in Massachusetts (Bull. Nutt. Orn. Club, II, Apr., 1877, 46). This leaves the species without even a New England record, but it has so often been taken on the North American coast (at various points from Labrador to North Carolina) as a straggler from the Old World, that its necurrence here is to be expected. 
23. Procellaria pelagica Linn. Stonмy Petrei.. Usually given as occurring off the coast, but I)r. Brewer doubts its right to a place among New England birds, since he has not been able to learn that a specimen has been taken (Proc. Bost. Soc. Nat. Hist., XVII, 1877, 453).

24. Puffinus anglorum Temm. Mank's Shlarwater. Commonly given as more or less frequent off the egast in winter, but Dr. Brewer (Proc. Bost. Soc. Nat. Hist., XVII, 1875, 453) claims that it has never beeu taken, and that it is not even a North American bird.

The Crested Grebe (Podiceps cristatus) has been commonly given as a rare winter visitant. Dr. Brewer says it has been inproperly ineluded as a bird of New England and that "its right to be regarded even as North American is also questioned" (Proc. Bost. Soc. Nat. Hist., XVII, 1875, 453). He has since shown that all the references to its capture in North America (Bull. Nutt. Orn. Club, III, Apr., $1878,52)$ are erroneous, as is now very generally conceded.

\section{Hypothetical and doubtful Species.}

1. Myiodioctes minutus Baird. Smarl-headed Flycatcher. Dr. Brewer retains this species as a bird of Massachusetts on the ground that Nuttall "states that Mr. Charles Pickering obtained a specimen of this bird many years ago, near Salem, Mass., and that he [Nuttall] had himself also seen it in the same State, at the approach of winter." Dr. Brewer further refers to a specimen "supposed to be of this species," and so identified by Mr. Audubon, that he once obtained in Roxbury, but admits that, as Audubon afterwards made no mention of it, the presumption is that he was mistaken as to the identity of the specimen. No specimen of this supposed species is extant, and it is ouly known from the descriptions and figures given long since by Wilson and Audubon. According to the latter the original locality was Kentucky. I agree with Dr. Coues that the species is one hardly entitled to recognition, and I prefer to discard it, for the present, as a bird of Massachusetts. (See Baild, Brewer and Ridgway's Hist. North Am. Birds, I, 1874, 316.)

2. Empidonax pygmæus Minot. "Pygmy Flycstcher." Only "caught sight of" "in soine shrubbery" "near Boston" by our young author, who "watched it for about three minutes," and then proceeded to describe it as a new species! No characters are given, by which it can be distinguished from any of the species of Empidonax, and those are half conjectural. The presumption of adding a "new species" on

- Land Birds and Game Birds of New England, 1877, 290. 
such a basis, in a group of birds so difficult of discrimination as to often puzzle experts with the specimens actually in hand, is certainly open to censure.

3. Thaumatias linnæi Bon. (Agyrtria naculata et linnci auct.) Liñacs's ExkralD. Supposed to have been taken in Massachusetts, and included in several lists. The probabilities seem to me to be strongly against the straggling of any South American Humming Bird to this state, and the history of this spccimen leaves room for doubt respecting its actual capture here. It was first recorded by myself (Am. Nat., III, Feb., 1870, 645), but with mnch hesitation. The clrcumstances of its supposed capture here have since been more fully investigated, and I now prefer not to recognize it as entitled to a record as a bird of Massachusetts.

\section{Introduced undomesticated Species, or probably introrluced either intentionally or accidentally.}

1. Passer domesticus Linn. House Spariow. Abundant near the larger towns and rapilly increasing, although the first importation was made scarcely ten years ago.

2. Carduelis elegans Steph. Europrax Goldrixcir. Repeatedly taken or observed in a wild state, under circumstances that seem to render it probable that the individuals were not escaped cage-birds. Whether or nut introduced originally by man's agency I consider seriously open to question.

3. Serinus meridionalis Brehm. SERin Fincir. Thus far only one record is known to me of its capture, - Springfield, Nov., about 1865 (Allen, Am. Nat., III, Jan., 1870, 635). Perhaps an escaped cage-bird, but the probabilities seem to me to be against this theory.

4. Coturnix communis Gray. European Quall. About one hundred of these birds were imported by Mr. Warren IIapgood in the spring of 1877, and distributed to various parts of the State. Only a few pairs are known to have raised young, and the result of the experiment is at present doubtful. The capture of a "young-cock bird" at Essex, Nov. 1, 1877, is recorded in "Forest and Stream" of Dec. 6, 1877 (p. 345). This importation consisted of two hundred and fifty birds, sixty-one of which died on the passage, leaving one hundred and eighty-nine for distribution on their arrival in Massachusetts about June 10. The same vessel brought a consignment of two hundred birds of this species to Judge Martin G. Evarts of Rutland, Vt., all but three of which are said to have reached Rutland alive. They were turned out June 9, and 11, 1877, and are reported to have bred plentifully. They disappeared from the neighborhood of Rutland about September 1, and have since been reported as seen (asicle from 
"bogus" reports of their flying out to sea) at various localities in the Southern States, the last authentic account up to the present writing representing several bevies as seen near Savannah, Ga., as late as December 10. (For a history of the introduction and migration of this species see "Forest and Stream" of issues of June 28, Aug. 2, Aug. 9, Aug. 23, Sept. 6, Nov. 15, Nov. 29, Dec. 6, and Dec. 27, 1877.)

5. Lagopus albus $A u d$. Willow Ptarmigan. The specimen taken in Manchester, in May, 1859, Dr. Coues conjectures was brought alive from Labrador or Newfoundland, and escaped (Proc. Essex Inst., V. 1868, 259).

6. Cupidonia cupido Baird. Prnsated Grouse. A few have been introduced at different times into Barnstable County, but none of them or their descendants are certainly known to still exist there.

Dr. Brewer informs me that several European Black-cap Warblers (Sylvia atricapilla) were at one time turned loose in Mount Auburn Cemetery, but are known to have all soon after died.

\section{General Summary.}

Fully authenticated as birds of the State ${ }^{10}$. . . . . 316

Extirpated . . . . . . . . . . . . . . . 4

Given as of probable occurrence . . . . . . . . . . 24

Considered as fairly entitled to recognition as Massachusetts birds 340

Known as breeding within the State (about) . . . . . 13ð

Extremely rare or accidental visitors . . . . . . . . 90

Introduced . . . . . . . . . . . . . . . . 6

North American species added since 1867. . . . . . . 35

\section{ADDENDUM.}

57bis. Pyranga ludoviciana Bon. Louisiana Taxagkr. Since this paper went to press a specimen of this western species has been takell alive in fotem, and its occurrence recorded by Dr. Brewer ("Forest and Stream," X, 95, March 14, 1878). It was captured Jan. 20,1878 , during the severest snow storm of the season, and being, in winter, a bird of Mexico, is presumed to have been involuntarily carried northward by the storm. It was an "adult female, and, though ravenous for food, was not in wasted condition."

10 Excluding "varieties" of other species represented.

Printed at the Salem Press, $\Lambda$ pril, 1878. 
145 
A Revised List of the Birds of Massachusetts.-By J. A. Allen.

Extracted from Bull. Amer. Mus. N. H., Vol. I, No. 7, July, 1886. 

Article XV.-A Revised List of the Birds of Massachusetts.-By J. A. Allen.

TWENTY-Two years have passed since the publication, in 1864 , of my first list of the birds of Massachusetts.* In 1870 I added some supplementary notes, $\uparrow$ and in 1878 published a new list of the birds of the State, $\ddagger$ revised to date. In the introduction to this "List" I called attention to the fact that during the previous ten years not less than thirty-four species had been added to the avian fauna of the State. During the eight years which have since elapsed twenty-two species have been added, many captures of other rarities have been recorded, and much has been learned respecting the mode of occurrence of many others, particularly the off-shore aquatic species. Besides this, the nomenclature of the subject has recently been greatly modified, and important changes made in the method of classification. It seems, therefore, desirable to once more bring the subject down to date, where it is my purpose to leave it to other and better hands.

In the introduction to my 1878 "List," I gave a somewhat detailed historical summary of the literature of Massachusetts ornithology, tracing the gradual increase of our knowledge of the subject from the date of Dr. Emmons's "Report," published in I 833, and containing the first formal list of the birds of the State, to the year 1878 . During this period the list of Massachusetts birds increased from 160 species to $32 \mathrm{I}$. It is not necessary to repeat this summary here; but a few words may be added in respect to the more recent investigations. 'These relate mainly to the sea-board, and the elevated region about Williamstown, and include observations of great interest on many of the rarer species.

In 1878 , in referring to the general subject of Massachusetts ornithology, I mentioned the region west of the Connecticut Valley as still presenting an inviting field for investigation, since it was evident that many species must breed in its more elevated

* Catalogue of the Birds found at Springfield, Mass., with Notes on their Migrations, Habits, etc., together with a List of those Birds found in the State not yet observed at Springfield. Proc. Essex Inst., Vol. IV, No. 2, pp. 48-98, July, 1864.

+ Notes on some of the Rarer Birds of Massachusetts. Amer. Nat., Vol. I1I, pp. 505-519, $568-585,631-649$, Dec. 1869 , Jan. and Feb. 1870 .

$\mp$ A List of the Birds of Massachusetts, with Annotations. Bull. Essex Inst., Vol. X, 1878 , pp. 3-37.

[July, r 886.] 
parts which do not commonly pass the summer in the central and eastern portions of the State. "This, in fact," I stated, "is known to be the case with a few, and is inferred for others. What is needed now to complete our knowledge of the ornithology of Massachusetts are exhaustive lists of the birds of at least two localities in Berkshire. County-one near its northern boundary and the other near its southern boundary. It is to be hoped that not many years will pass before these desiderata will be supplied."

A part of this interesting field has since been hastily examined by Mr. William Brewster, who spent from June 2 I to June 29, $188_{3}$, in exploring the region about Williamstown and Graylock Mountain, with results of the highest interest.* The breeding there, previously only inferred, of a number of species was not only confirmed, but four not before known to breed anywhere in the State were found to be common summer residents. Graylock, in short, proved to be, faunally speaking, "a Canadian Island rising from an Alleghanian sea," in which were found breeding many species not known to nest elsewhere in New England south of Maine, New Hampshire, and Vermont. While Mr. Brewster's brief visit to Mount Graylock has added so much to our knowledge of the birds of the western part of the State, Berkshire County, particularly its southwestern portion, still offers an inviting field for ornithological exploration.

In respect to the coast birds, Mr. R. L. Newcomb's notes on the Grallæ, $\nmid$ 'based on an experience of twenty years' collecting and shooting on the Massachusetts coast, chiefly in Essex County, give valuable and explicit information respecting the relative abundance of the so-called Shore Birds, nearly thirty species of which are briefly mentioned. Mr. William Brewster, in his review of Part II of Stearns and Coues's "New England Bird Life," $\ddagger$ also takes occasion to correct many long-standing errors regarding the relative abundance and seasons of occurrence of various species of Ducks, Petrels, and Shearwaters, based on his thorough knowledge of our coast birds. It is to be hoped he will be able

* Notes on the Summer Birds of Berkshire County, Massachusetts. Auk, Vol. I, Jan. 1884, pp. 5-16.

† Notes on Shore Birds. Forest and Stream, Vol. XXII, No. 25, pp. 483, 484, July 17, 1884 .

$\ddagger$ Bull. Nutt. Orn. Club, Vol. VIII, I883, pp. r6r-164. 
soon to give us more fully the results of his mature experience with our water birds, respecting which so little is still satisfactorily recorded.

As bearing upon the general subject of Massachusetts ornithology, mention should be made in this connection of Stearns and Coues's handy manual of New England ornithology, ${ }^{*}$ which gives not only the bibliography of the subject (Vol. I, pp. 42-50) to I879, but detailed references to the records of the rarer species occurring in Massachusetts and the adjoining States. In the compilation of these scattered records the authors give credit for valuable assistance to Mr. H. A. Purdie, of Boston, whose familiarity with the subject, and whose trustworthiness in such matters are well known.

As already stated, twenty-two species of birds have been added to the fauna of the State since the publication of my 1878 "List," including one (Puffinus borealis . Cory) new to science. The number of species then recorded was 317 (including one given in an "Addendum" and not numbered consecutively in the list), plus four extirpated, making a total of $32 \mathrm{I}$. The present list numbers 339 , plus four extirpated, or 443 in all. Of the 24 species then given as of probable occurrence, six have been since taken within the limits of the State; six others have been recorded as taken in the Connecticut Valley, within six to ten miles of the southern boundary of Massachusetts.

The present list, as was the former, is divided into five categories, namely: (I) species fully authenticated as birds of the State; (2) species of probable occurrence; (3) extirpated species; (4) doubtful species; (5) introduced species. The classification and nomenclature adopted is that of the new A. O. U. Check List of North American Birds. $\dagger$

An asterisk $(*)$ prefixed to the current number of a species indicates that it is either known to breed in the State, or that it occurs in summer under circumstances that render its breeding almost unquestionable. A species having its current number in-

* New England Bird Life: being a Manual of New England Ornithology. Revised and edited from the manuscript of Winfrid A. Stearns. By Elliott Coues. Boston: Lee \& Shephard. 8vo. Vol. I, r881, pp. 324. Vol. II, 1883, pp. 409.

+ The Code of Nomenclature and Check List of North American Birds, adopted by the American Ornithologists' Union ; being the Report of the Committee of the Union on Classification and Nomenclature. New'York, 1886. 8vo, pp. viii. +392. 
closed in brackets is to be regarded as a casual or accidental visitor only, or so rare as to render it practically an extraneous element of the fauna. The annotations are intended as merely a brief indication of the manner of occurrence of the species, particularly as regards season and relative abundance. The records of capture of the rare or accidental visitors are fully given for the last ten years, and generally for the last twenty years, or for the interval since the publication of my first Catalogue in 1864 . The earlier records are generally omitted, but they were included in the 1864 list. These three lists- 1864,1878 , and the presentwith the "Notes" published in 1870 , give a nearly exhaustive record of the occurrences of the rarer birds of the State. As a matter of correlative interest, reference is also made, in most such cases, to records of capture in adjoining States, as tending to indicate the probable status of the species as a Massachusetts bird. With few exceptions only the original record is cited.

\section{I. - SPECIES FULLY AUTHENTICATED AS BIRDS OF THE} STATE.

1. Colymbus holbolli. Holbell's Grebe.-Chiefly a winter visitant; not common. Has been taken late in May, in full breeding plumage.

2. Colymbus auritus. Horned Grebe.-Chiefly a winter visitant; not common. A few remain in summer.

*3. Podilymbus podiceps. Pied-Billed Grebe.-Rather rare resident; more common in spring and fall than at other seasons.

*4. Urinator imber. Loon.-More or less frequent resident in portions of the State, but much more numerous in winter than at other seasons.

5. Urinator lumme. RED-throated Loon.-Common winter visitant along the coast ; rare in the interior ; most numerous in autumn and spring.

6. Fratercula arctica. Puffin.-Not uncommon winter visitant along the coast.

[\%.]? Simorhynchus cristatellus. Crested Auklet.-A small Crested Auk was killed at Chatham, during the winter of 
I 884-85. The specimen was not preserved, and the record rests wholly on the testimony of an unscientific but intelligent and otherwise trustworthy observer, as recorded in "The Auk" of October, I 885 (II, 388). While the identity of the species cannot therefore be given with certainty, there is very little reason to doubt the determination here made.

8. Cepphus grylle. Black Guillemot. - Rather common winter visitant, mostly off the coast.

9. Cepphus mandti. Mandt's Gullemot.-Off the coast in winter; not common.

10. Uria troile. MURRE.-Rare or irregular winter visitant along the coast. (See Brezester, Bull. Nutt. Orn. Club, VII, I882, 25I.)

11. Uria lomvia. BRÜNINCH's MURRE.-Common winter visitant along the coast.

12. Alca torda. Razor-billed Auk. - Not uncommon in winter along the coast.

13. Alle alle. Dovéie.-Irregular and generally rare winter visitant along the coast; occasionally common. Of accidental occurrence in the interior, having been taken as far from the coast as Springfield.

[14.] Megalestris skua. SkuA.-Rare or accidental off the coast. The only record is George's Banks, July, I878 (Brezeer, Bull. Nutt. Orn. Club, III, I878, I88). Mr. William Dutcher informs me that a specimen, now in his cabinet, drifted ashore dead on Long Island, N. Y., in January, I886; and it may occur sparingly off the whole New England coast.

15. Stercorarius pomarinus. Pomarine JAEger.-A not common spring and autumn visitant along the coast.

16. Stercoririus parasiticus. Parasitic JaEger.-A regular spring and fall migrant along the coast.

1\%. Stercorarius longicandus. Long-TAILEd JAEger.Rare in spring and fall along the coast.

The three Jaegers have usually been regarded as winter visitors, but fishermen and gunners along the coast say that none of these I 886.] 
birds are seen by them in the winter, but that they occur along the coast in autumn, and again in the spring.

18. Rissa tridactyla. KittiwaKe.-Common in winter along the coast.

[19.] Larus glaucus. Glaucous Gull.-A rare straggler in winter from the north.

20. Larus leucopterus. Iceland Gull.-Rare winter visitor. Recent records are Boston, Jan. 3 I, I880 (Bangs, Bull. Nutt. Orn. Club, VI, I88I, I 24), and November, I88̊ı (Cory, ibid., VII, I882, $60)$.

21. Larus marinus. Great Black-Backed Gull.-Common winter visitant.

[22.] Larus argentatus. Herring GuLL.-Rare or casual. I have examined several specimens taken along the coast of Essex County.

22a. Larus argentatus smithsonianus. American Herring GulL.-Abundant winter visitant; a few remain along the coast in summer, where formerly they probably bred.

23. Larus delawarensis. Ring-Billed Gull.-Rather uncommon on the coast in spring and fall. (See Brezester, Bull. Nutt. Orn. Club, VIII, I883, I63.)

*24. Larus atricilla. Laughing Gull.-Formerly a not uncommon summer visitant; now nearly extirpated from our coast.

25. Larus philadelphia. Bonaparte's Gull - Common spring and fall visitant; some remain in winter.

[26.] Xema sabinii. Sabine's Gull-Accidental. The only Massachusetts record is Boston Harbor, Sept. 27, I874 (Brezester, Am. Sportsman, V, $\mathrm{I} 875,370)$; but it has been taken at Portland and Calais, Maine (Allen, Bull. Nutt. Orn. Club, III, I 878, 195).

[2\%.] Gelochelidon nilotica. Gull-billed Tern. - Accidental. The only Massachusetts record of this southern species is Ipswich, Sept. I87 I (Brewster, Am. Nat., VI, 1872, 306). A specimen, however, has been recorded as taken at Grand Menan, during the latter part of August, I879 (Deane, on authority of G. A. Boardman, Bull. Nutt. Orn. Club, V, I880, 63). 
28. Sterna tschegrava. Caspian Tern.-Regular and not rare spring and fall migrant along the coast (Brezester, Bull. Nutt. Orn. Club, IV, 1879, I4).

[29.] Sterna maxima. Royal Tern.-Accidental. Two specimens were taken by Messrs. Maynard and Brewster on Nantucket Island, July I, I874 (Am. Sports., V, 249, Jan. I6, I875)thus far the only authentic record.

[30.] Sterna sandvicensis acuflavida. Савот's Tern.Accidental. One record only-Chatham, August, 1865 (Allen, Am. Nat., III, Feb. 1870, 644).

31. Sterna forsteri. ForSter's TERn.-Of rare but probably regular occurrence in autumn along the coast (Brezester, Am. Nat., VI., I872, 306; Purdie, ibid., VII, 1873, 693). I saw a number at Chatham in August, 1885 .

*32. Sterna hirundo. Common Tern.-Common summer resident along the coast; formerly abundant.

*33. Sterna paradisaa. Arctic Tern.-Common summer resident along the coast; formerly abundant.

*34. Sterna dougalli. Roseate Tern.-Not uncommon along the coast in summer, but much less numerous than formerly.

*35. Sterma ayítillarum. Least Tern.-Common along the coast in summer.

[36.] Sterna fuliginosa. Sооту Tern.-Accidental. There are three recent records of its capture in Massachusetts : Lawrence, Oct. 29, 1876 (Deane, Bull. Nutt. Orn. Club, II, 1877, 27); Williamstown, Sept. 1876 (Tenney, Am. Nat., XI, I877, 243); Chatham, Sept. 1877 (Brezver, Proc. Bost. Soc. Nat. Hist., XIX, r 878,308 ). It has, however, been taken several times in the adjoining States, as follows: Saybrook, Conn., summer of 1876 (Purdie, Bull. Nutt. Orn. Club, II, I877, 22); Granby, Stony Creek, and Faulkner's Island, Conn., autumn of 1876 (Merriam, Rev. Birds Conn., I877, I34, I35); Point Judith, R. I. (Merriam, ibid., I34); Parkman, Piscataquis Co., Me., Oct. 5, 1878 (Deane, Bull. Nutt. Orn. Club, V, r880, 64); Rutland, Vt., 1876 (Brewer, Proc. Bost. Soc. Nat. Hist., XX, I880, 276). It will be observed that nearly all of the specimens here mentioned were taken in the I886.] 
autumn of $\mathrm{x} 876$, mostly in September, indicating a remarkable invasion of these birds into New England in the fall of that year. Mr. William Dutcher informs me of a specimen taken on Long Island in 1878 .

3\%. Hylochelidon nigra surinamensis. BLACK TERn.Of somewhat irregular occurrence along the coast in August; sometimes not uncommon, particularly at Nantucket and near Chatham. There are numerous recent records for the New England coast, including that of New Hampshire and Maine as well as Massachusetts. On their occurrence in Massachusetts see Brewester, Bull. Nutt. Orn. Club, III, 1878, 190; Cahoon, Orn. and Oöl., IX, I884, I5 I. I found them in numbers at Chatham in August, I885, and a large flight is reported as seen there during the first week of September of the same year ( $F . B . W[e b s t e r]$, Orn. and Oöl., X, I885, I60). See especially notes on this flight by Mr. J. C. Cahoon (Orn. and Ö̈l., XI, ı 866, го), who reports seeing " as many as several hundred during the day [Aug. 3I]; saw one flock of twenty-three sitting on the flats, but did not observe an adult among them."

[38.] Rynchops nigra. Black Skimmer.-Of casual occurrence along the coast, from Long Island to Maine. (See especially Deane and Brewer, Bull. Nutt. Orn. Club, IV, 1879, 242, 243). Perhaps formerly not uncommon on the coast of Massachusetts (Purdie, ibid., VIII, I882, 125).

[39.] Fulmarus glacialis. Fulmar.-Rare or accidental off the coast. The only record is George's Banks, Nov. I 878 (Brezerer, Bull. Nutt. Orn. Club, IV, ז879, 64).

40. Puffinus borealis. Cory's Shearwater.-Off the coast, at times apparently not uncommon. There are thus far, however, but two records-off Chatham Island, Cape Cod, Oct. II, I880 (Cory, Bull. Nutt. Orn. Club, VI, I88I, 84, where the species was first described), and again taken near the same place, August 2, I 883 (Job, ibid., VIII, I 883,244 ). A considerable number of specimens were obtained by Mr. Cory and many others were seen; Mr. Job secured three.

41. Puffimus major. Greater Shearwater.-Abundant off the coast in summer. 
42. Puffinus stricklandi. Sooty Shearwater.-Abundant off the coast in summer.

This and the preceding species have hitherto usually been regarded as winter visitors, but intelligent fishermen and gunners assure me that no species of Shearwater is seen by them off the Massachusetts coast in winter.

43. Oceanodroma leucorhoa. Leach's Petrel.-Common summer visitant along the coast. Breeds on the coast of Maine.

44. Oceanites oceanicus. Wilson's Petrel.-Common off the coast in summer.

[45.] Pelagodroma marina. White-faced Petrel-Accidental. The only record is off the coast, Sept. 2, I885 (Ridgway, Auk, II, 1885, 386).

[46.] Sula sula. Воову.-Rare or accidental. Thus far there is only one recent record-Cape Cod, Sept. I7, I878 (Brewer, Bull. Nutt. Orn. Club, IV, I879, I9r). But there is an earlier and perhaps doubtful record, namely, Essex County, "September, rare" (Putnam, Proc. Essex Inst., I, 1856, 22 I).

4\%. Sula bassana. Gannet.-A not uncommon migrant in early spring and late fall. Not a winter visitant, as usually stated, according to the testimony of fishermen and gunners.

48. Phalacrocorax carbo. Cormorant--Rare in spring and fall, and probably rare in winter. (See Brewster, Auk, II, II 2.) Winters from the coast of Maine northward, straggling at the same season southward to New Jersey, and even South Carolina. Is supposed to have formerly bred from Massachusetts northward. A recent Rhode Island record, of interest in this connection, is Newport, March 27 and April ıo, 1884 (Jencks, Random Notes on Nat. Hist., II, I 885,34$)$.

49. Phalacrocorax dilophus. Double-Crested Cormorant. -Common spring and fall migrant.

[50.] Pelecanus erythrorhynchos. American White PeliCAN. - Now accidental ; formerly common (Allen, Bull. Nutt. Orn. Club, I, I876, 60). 'The only recent correct record of its capture appears to be North Scituate, Oct. 6, I 876 (Purdie, Bull. I 886.] 
Nutt. Orn. Club, II, 1877,22$)$. The specimens reported by me (Am. Nat., III, 1870,640 ) as taken at Ipswich and Nantucket were found later to be $P$. fuscus. (See remarks under $P$. fuscus.) There is, however, a recent New Brunswick record (Chamberlaine, Bull. Nutt. Orn. Club, VII, 1882, 106).

- [51.] Pelecanus fuscus. Brown Pelican.-Accidental. Ipswich (Maynard, Nat. Guide, I870, 149); Nantucket (Allen, Am. Nat., III, Feb. I870, 640), but wrongly given as $P$. erythrorhyncos.*

52. Merganser americanus. American Merganser.-Common winter visitant, but most numerous in fall and spring. Probably formerly bred in the State.

53. Merganser serrator. Red-breasted Merganser.Common in spring and fall, many remaining in winter.

54. Lophodytes eucullatus. Hooded Merganser.-Rather common spring and autumn visitant, many remaining in winter, and a few perhaps in summer.

*55. Anas boschas. Mallard.-A very rare straggler in spring and fall. Said to breed regularly at Somerset (Coues and Slade, Bull. Nutt. Orn. Club, VIII, I883, I86).

*56. Anas obscura. Black Duck.-Abundant winter resident, and rare in summer; doubtless formerly regularly resident the whole year. A recent record of its breeding in the State is Rehoboth (F.H.C[arpenter], Orn. and Oöl., IX, 1884, I25).

5\%. Anas strepera. Gadwall.-Rare spring and autumn visitant; perhaps only accidental. (See Brewester, Bull. Nutt. Orn. Club, VIII, 1883, I63.)

58. Anas americana. Baldpate.-Spring and autumn visitant. Rare.

59. Anas carolinensis. Green-winged Teal.-Rather uncommon spring and autumn migrant (Brezester, Bull. Nutt. Orn. Club, VIII, I878, I63).

60. Anas discors. Blue-Winged Teal.-Rather rare spring, and abundant autumn, migrant; formerly doubtless a summer resident. (See Brewster, Bull. Nutt. Orn. Club, VIII, I883, I63.)

* Corrected in a note added to last page of author's extras, in which it is stated that "from information just received there is every reason for believing that this flock [of White Pelicans, mentioned on page 40 (of extras) as having visited Nantucket Island,] were Brown Pelicans." 
61. Spatula clypeata. Shoveller.-Rare spring and autumn visitant. It was formerly, judging from its present breeding range in the interior, a frequent summer resident. (Cf. Brown, on its occurrence at Portland, Maine, Bull. Nutt. Orn. Club, VI, I88I, I87.)

62. Dafila acuta. Pintail. "Gray Duck" of gunners.Rare winter visitant.

*63. Aix sponsa. Wood Duck.-Common summer resident.

64. Aythya americana. REDHEAD.-Rare spring and autumn migrant.

65. Aythya vallisneria. CAnvas-BACK.-Very rare spring and autumn visitant.

66. Aythya marila nearctica. American Scaup Duck.Not common spring and autumn visitant, some remaining in winter.

6\%. Aythya affinis. Lesser Scaup Duck.-Spring and fall migrant; not common.

68. Aythya collaris. Ring-NECKed Duck.-Kare spring and autumn migrant.

69. Glancionetta clangula americana. AMERICAN GoLdenEYE.-Common winter resident.

70. Glaucionetta islandica. BARRow's GOLDEN-EYE.-Rare winter visitant. Only recently added to the fauna of the State on record of its actual capture (Brewester, Am. Nat., VI, May, 1872, 306). There is also a Connecticut record (Merriam, Rev. Bds. Conn., 1877, 126).

71. Charitonetta albeola. Butterbal.L.-Common winter visitant.

92. Clangula hyemalis. Old SQuaw. - Common winter visitant.

73. Histrionicus histrionicus. Harlequin DuCK.-Rare winter visitant. Formerly, like most of the Ducks, more common than now (Brewer, Bull. Nutt. Orn. Club, II, I877, 46). Still common in winter on the coast of Maine (Brezester, ibid., VIII, $\left.188_{3}, 163\right)$.

I886.] 
[74.] Camptoliemus labradorius.-Labrador Duck.-Formerly a not uncommon winter visitant; no recent record of its capture in this State. "Abundant" in Boston market fifty years ago (Brewer, Bull. Nutt. Orn. Club, II, I877, 46). The specimens figured by Audubon were killed by the "Honourable Daniel Webster of Boston..... on the Vineyard Islands." The latest record of its capture anywhere is Elmira, Chemung County, N. Y., Dec. I2, I878 (Gregg, Am. Nat., XIII, I879, I28).

[75.] Somateria mollissima. Eider.-Doubtless a rare winter straggler from the north. (See Brewster, Auk, II, I885, I11.)

76. Somateria dresseri. American Eider.-Not uncommon in spring and fall, some remaining in winter.

7\%. Somateria spectabilis. KING EIder.-Rare winter visitant.

78. Oidemia americana. AMERICAN SCOTER.-Common in spring and fall, and not rare in winter.

79. Oidemia deglandi. White-Winged Scoter.-Common winter visitant. More common than the last or next.

80. Oidemia perspicillata. Surf SCOTER.-Common winter visitant.

81. Erismatura rubida. Ruddy Duck.-Rather common winter visitant, but most numerous in fall and spring.

[82.] Chen hyperborea. Lesser Snow Goose.-Rare or accidental winter visitor. Several specimens have come to my knowledge, taken in Massachusetts, which seem referable to this form.

82a. Chen hyperborea nivalis. Greater Snow Goose.Rare winter visitant.

83. Anser albifrons gambeli. American White-Fronted Goose.-Rare spring and fall migrant. Some years since I found specimens in the Boston markets I had reason to believe were killed in this State. Dr. Brewer says it was more common forty to fifty years ago than now, as was the case with many of our other Ducks and Geese (Bull. Nutt. Orn. Club, II, x877, 46).

84. Branta canallensis. CANADA Goose.-Common spring and autumn visitant; probably formerly a summer resident. 
84a. Branta canadensis hutehinsi. Hutchin's Goose.Rather irregular rare spring and autumn visitant, but more common formerly. (See Brewer, Bull. Nutt. Orn. Club, II, I877, 46; Brewester, ibid., VIII, I883, 163 .)

85. Branta bernicla. BRANT.-Not uncommon spring and autumn migrant.

[86.] Branta leucopsis. Barnacle Goose.-Accidental. The only Massachusetts record is North Chatham, Nov. I, I885 (F. H. C [arpenter], Orn. and Oöl., XI, І 886, І6). The specimen was mounted by Mr. N. Vickary of Lynn, who also informed me of its capture in a letter.

There are numerous extralimital records for eastern North America, it having been taken in Southern Labrador, Maine, Vermont, on Long Island, and in North Carolina.

87. Branta nigricans. BlaCK BRAnt.-Rare or accidental, with the preceding. Though commonly attributed to the State there are thus far few positive records of its capture here. (See Brewer, Proc. Boston Soc. Nat. Hist., XVII, 1875, 447; Cory, Auk, I, I884, 96.)

[88.] Olor columbianus. Whistling Swan.-In early times (first half of the seventeenth century) this species was not uncommon (see Allen, Bull. Nutt. Orn. Club, I, 1876,58 ), but at present it can be regarded only as a rare and irregular, perhaps accidental, visitor. Recent authentic records are Nantucket, March 4, I 878 (Brezoster, Bull. Nutt. Orn. Club, III, r878, r98); Nahant, about I 865 (Brewer, Proc. Bost. Soc. Nat. Hist., XX, I879, 274); Somerset, Oct. I6, I880 (Slade, Bull. Nutt. Orn. Club, VI, I88r, 123). There are also recent records for New Hampshire (Seabrook, Brezester, Bull. Nutt. Orn. Club, IV, I879, I25), Connecticut (Branford Harbor, Merriam, Rev. Bds. Conn., I877, I 20), and Rhode Island (Dexter, Forest and Stream, XIII, I879, 848). Also St. John, N. B. (Gilbert, Canad. Nat. and Sportsman, II, I 882, I 44 ).

[89.] Plegadis autummalis. Glossy Ibis.-Accidental. Several early records of its occurrence, but only three recent ones: Nantucket, Sept. I869 (Allen, Am. Nat., III, I870, 637); Cape Cod (Orleans and Chatham), three specimens, about May 5, 1878 I886.] 
(Brezerer, Bull. Nutt. Orn. Club, III, 1878, I5 I; Cory and Allen, ibid., I 52). A detailed history of the occurrence of this bird in Massachusetts and neighboring parts of New England is given in Stearns and Coues's "New England Bird Life" (II, I 883, 254-257).

[90.] Tantalus loculator. Wood IBIs.-Accidental. Recorded by me (Bull. Nutt. Orn. Club, VIII, i 883, 187), on what has proved to be doubtful authority, as taken at Georgetown, June 19, I880. The authenticity of the alleged capture has since been investigated with care, without eliciting any evidence tending to impeach the record, beyond the fact of the untrustworthy character of my informant (see Auk, I, I884, 295-297). The capture of the species at Glasco, Ulster County, N. Y., July 8, 1884 (Fisher, Auk II, I885, 22I), not far from the western border of the State, and also at Troy, N. Y., at Williamsport, Penn. (Allen, Bull. Nutt. Orn. Club, I, I876, 96), Elizabethtown, Lancaster Co., Penn. (Sherratt, Orn. and Oül., IX, I884, I15), and in West Virginia (Wall, American Field, XXII, I 884, 82), shows that the species occasionally wanders far beyond its usual range, and thus gives probability of its occurrence in Massachusetts.

*91. Botaurus lentiginosus. American Bittern.-Common summer resident.

*92. Botamrus exilis. LeAst Bittern.-Not generally common, but rather frequent at some localities.

*93. Ardea herodias. Great Blue Heron.-A not common summer resident.

[94.] Irdea egretta. American Egret.-Accidental. Several comparatively recent instances of its capture have been recorded (Hudson, Ashland, and Lynn, Allen, Am. Nat., III, I870, 637 ; Westford, 1873, Purdie, Am. Nat., VII, 693). Also Saybrook, Conn., Aug. I I, I88 I (Sage, O. \& O., VII, I89, and ibid., VIII, 4). -It has been taken also in New Brunswick (Grand Menan), Nov. 3, 1878 ), and Halifax, Nova Scotia (Deane, Bull. Nutt. Orn. Club, IV, 1879,63 ). For references to earlier records of this and the two following species see Stearns and Coues's "New England Bird Life," Vol. II, I883, 260-264. 
[95.] Ardea candidissima. Snowy Heron.-Accidental. There are fewer recorded instances of the occurrence of this species than of the preceding. A recent one is Nantucket, March, I882 (Purdie, Bull. Nutt. Orn. Club, VII, I882, 25 I).

[96.] Ardea carulea. Little Blue Heron.-Accidental. While there is no recent record of its capture in Massachusetts, it may be of interest to note the following: Scarborough, Maine (Browen, Bull. Nutt. Orn. Club, VII, r882, I23) ; Saybrook, Conn. (Clark, Orn. \& Ö̈l., VII, I882, 5r); Warwick, R. I., July I3, I878 (Deane, Bull. Nutt. Orn. Club, V, I880, I23).

*97. Ardea virescens. Green Heron.-Common summer resident.

*98. Nycticorax nycticorax nevius. BLACK-CROWNED Night Heron.-Common summer resident. Stragglers have been observed at Cambridge in winter.

[99.] Nycticorax violaceus. Yellow-Crowned Night Heron. - Accidental. Two records : Lynn, Oct. x862 (Allen, Am. Nat., III, 1870, 637); Somerville, July 30, 1878 (Brewester, Bull. Nutt. Orn. Club, IV, 1879, I24).

[100.] Rallus elegans. King RaIL.-Rare or accidental. Nahant, Nov. 21, 1875 (Purdie, Bull. Nutt. Orn. Club, II, r877, $22)$; Sudbury Meadows, "some years since" (Purdie, ibid., III, I878, I46). A rare summer resident in Southern Connecticut (Merriam, Rev. Bds. Conn., I15).

[101.] Rallus longirostris crepitans. Clapper Rail.-Rare or accidental. Boston Harbor, May 4, 1875 (Purdie, Bull. Nutt. Orn. Club, II, 1877, 22) ; Plymouth, Oct. 1879 (Purdie, ibid., VI, I881, 62). It has also occurred near Portland, Maine (Browon, ibid., IV, 1879 , ro8), and has been repeatedly taken in Connecticut (Merriam, Rev. Bds. Conn., I877, I15).

*103. Rallus virginianus. Virginia Rail.-Common summer resident.

*103. Porzana carolina. Sora. - Common summer resident.

104. Por\%ana noveboracensis. Yellow Rallo-Rare summer visitant, but occasionally common at some localities, as at Plymouth (Brezester, Bull. Nutt. Orn. Club, VI, r88i, r86). 'Has r 886.] 
also been recorded from Maine and New Brunswick, as well as Connecticut.

*105. Porzana jamaicensis. Black Rall.-Very rare, perhaps accidental, summer visitant. One instance only of its capture in Massachusetts hitherto recorded (Clark's Isl., Plymouth Harbor, Aug. 1869, Purdie, Bull. Nutt. Orn. Club, II, I877, 22). As yet only two records of its capture in Connecticut, where it has been found breeding (see Merriam, Rev. Bds. Conn., r877, Ir9).

I now add another Massachusetts record, on information furnished me by Mr. A. W. Baker, who found a pair at Chatham with young in July, 1884, and a nest with four eggs in May, 1885.

[106.] Ionornis martinica. Purple Gallinule.-Accidental. A recent record of its occurrence is Rockport, April I 2, I 875 (Whitman, Am. Nat., IX, I875, 674). More easterly recent records are Calais, Me. (Boardman, Am. Nat., III, 498) ; Boothbay, Me. (Purdie, Bull. Nutt. Orn. Club, V, r88o, 242); Halifax, Jan. 30, I870 (Jones, Am. Nat., IV, 253); New Brunswick, two instances (Brewster, Bull. Nutt. Orn. Club, VI, I88 I, I86 ; Chamberlaine, ibid., VII, I882, I05). A new Rhode Island record is Westerly, about 1857 (Jencks, ibid., VII, r88I, r24). (For references to earlier records see Stearns and Coues's "New England Bird Life," II, r883, 293.)

*10\%. Gallinula galeata. Florida Gallinule.-Rare summer visitant, doubtless occasionally breeding (see Allen, Am. Nat., III, Feb. 1870, 639). Recent records are Nantucket, Oct. 1872 (Brewer, Bull. Nutt. Orn. Club, IV, I 879, 63), and Wayland, Sept. Io, I 878 (Brewer, Proc. Bost. Soc. Nat. Hist., XX, 273). A recent New Brunswick record is Dick's Lake, Sept. 1880 (Brewester, Bull. Nutt. Orn. Club, VI, I88I, I86). Given as rather common in Connecticut by Merriam (Rev. Bds. Conn., I877, r9).

*108. Fulica americana. American Coot.-Rare summer resident; more numerous in fall and spring.

109. Crymophilus finlicarius. Red Phalarope. - Not common spring and autumn migrant, chiefly off the coast. Rarely taken. "Well out in Massachusetts Bay," Aug. 31, I878 (Nerecomb, Bull. Nutt. Orn. Club, IV, 1879, I27 ; Forest and Stream, XXII, No. 25, July I 7, I 884,484 ). 
110. Phalaropus lobatus. Northern Phalarope.-Spring and fall migrant, chiefly off the coast. Mr. Brewster mentions it as "of by no means rare occurrence in Boston market, from Cape Cod and elsewhere along the Massachusetts coast.... It is, however, like several other off-coast species, not commonly found near the land unless forced to take shelter from severe storms" (Bull. Nutt. Orn. Club, III, 1878, I52). Swampscott (Nerwcomb, Forest and Stream, XXII, No. 25, July I7, I884, 484). A recent inland record is Ware, Oct. 13, I875 (Stearns, Bull. Nutt. Orn. Club, V, I880, 122).

111. Steganopus tricolor. Wilson's Phalarope. - Very rare. No recent nor very explicit Massachusetts records. Doubtless not uncommon in migrations off the coast. Taken at Newport, R. I., Aug. 2, I880 (Jencks, Bull. Nutt. Orn. Club, V, r88o, 237). There are several recent Long Island records.

[112.] Recurvirostra americana. American Avocet.-Accidental. Natick, Oct. 19, 1880 (Purdie, Bull. Nutt. Orn. Club, VI, I88I, I23). Interesting extralimital records are near Saybrook, Conn. (Merriam, Rev. Bds. Conn., 1877, ro3); Point Lepreaux, N. B., I 862 (cf. Brewer, Proc. Bost. Soc. Nat. Hist., XVII, I875, 452); Quaco, N. B., I880, three specimens (Boardman, Bull. Nutt. Orn. Club, V, 1880, 24I), and St. Martins, N. B. (Chamberlaine, ibid., VII, I882, 105). At the latter place one or more of these birds reported as taken each year for the five preceding years, two usually being met with together.

[113.] Himantopus mexicanus. Black-necked Stilt.Accidental. Mr. Maynard gives it, on the authority of gunners and others, "as occasionally seen along the sandy beaches" (Nat. Guide, r870, I43). Mr. Boardman saw, some years since, two specimens in a Boston market, which he was assured were taken in this State (Allen, Am. Nat., III, 1870, 638). It has been taken at Calais, Maine (Boardman, Proc. Bost. Soc. Nat. Hist., IX, r862, I28), and in New Brunswick (Chamberlain\}, Bull. Nutt. Orn. Club, VII, 1882, 105), where several had been taken at Mace's Bay during former years.

*114. Philohela minor. American Woodcock.-Common summer resident.

I886.] 
*115. Gallinago delicata. Wilson's Snipe.-Common during migrations, and a rather rare summer resident. A few pass the winter at favorable localities.

116. Macrorhamphus griseus. Dowicher.-Rather common spring and autumn migrant.

11\%. Macrorhamphus scolopaceus. Long-BILled DowichER.-Not infrequent spring and fall migrant. (This, in my 1878 "List," was combined with the preceding.)

118. Micropalama himantopus. Stilt SandPIPER. - Not common, and occurring chiefly during the autumnal migration. For the history of this bird's mode of occurrence and distribution in Massachusetts, and along the New England coast generally, see Stearns and Coues's "New England Bird Life" (II, r883, 2062 I2), and the references there given.

119. Tringa canutus. KNot.-Common spring and autumn visitant.

120. Tringa maritima. Purple Sandpiper.-Not uncommon in winter along rocky shores.

121. Tringa maculata. Pectoral Sandpiper.-Rare during its spring migrations, but common "from July 10 or 15 until quite late in the fall" (Newcomb, Forest and Stream, XXII, No. 25 , July I $7, \mathrm{x} 883,483$ ).

122. Tringa fuscicollis. White-rumped Sandpiper.-Common spring and fall migrant.

[123.] Tringa bairdi. Baird's SandPIPER.-Rare or casual. The records are Long Island, Boston Harbor, Aug. 27, 1870 (Brewster, Am. Nat., VI, 1872, 306); Swampscott, Aug. 27, 1876 (Brewer, Bull. Nutt. Orn. Club, III, 1878, 140); Marblehead, Aug. I5, I88 I (Lamb, Journ. Bost. Zoöl. Soc., I, 1882, 37). There are also records for New Hampshire, Maine, and Long Island, N. Y.

124. Tringa minutilla. Least Sandpiper.-Abundant during its migrations.

125. Tringa alpina pacifica. RED-BACKed SANDPIPER.Rare spring and common autumn visitant; a few sometimes remain in summer. 
[126.] Tringa ferruginea. Curlew Sandpiper.-Rare or accidental in spring and fall. According to Dr. Brewer, there was no authenticated instance of its occurrence in New England on record prior to 1875 , when he announced the capture of a specimen "recently taken" in Ipswich (Proc. Bost. Soc. Nat. Hist., XVII, I875, 446). Mr. E. A. Samuels, however, refers to its having been shot on Cape Ann in 1865 (Orn. and Oöl., New Eng., 1868, 447). Mr. Brewster has since recorded its capture in East Boston, early in May, 1866 (Bull. Nutt. Orn. Club, I, I876, 5 I). Mr. Deane has added Cape Cod, May io, I 878 , and Nahant (ibid., IV, I879, I 24). It has also been taken at Scarborough, Me., Sept. 15, I88I (Purdie, ibid., VII, I882, I24), and there are several Connecticut records.

12\%. Ereunetes pusillus. Semipalmated Sandpiper. Abundant during its migrations; a few sometimes met with in summer.

[128.] Ereunetes occidentalis. Western Sandpiper. Doubtless of casual occurrence merely. Long Island, Boston Harbor, Aug. 27, 1870 (Henshaw, Auk, II, 1885, 384). Has recently been found in numbers on the coast of Maryland and Virginia (Beckham, ibid., II, 1885, Iro ; Smith, ibid., II, 1885, 285).

129. Calidris arenaria. Sanderling. - Abundant spring and autumn migrant; stragglers sometimes remain in summer.

130. Limosa fedoa. Marbled Godwit.-Rare spring and autumn visitant. Ipswich, July I7, I869 (Maynard, Nat. Guide, 1870, 142). Dr. Brewer says " A few are seen both in their spring migrations and in the fall, in the more easterly portions of Barnstable County" (Water Birds of North America, I, I884, 257).

131. Limosa hemastica. Hudsonian Godwit.-Of rare or irregular occurrence, chiefly in the fall; sometimes not uncommon.

132. Totanus melanolencus. Greater Yellow-legs. Common spring and autumn migrant, and a few linger in summer.

133. Totanus flavipes. Yellow-Legs. - Occasional spring and common autumn visitant; rare in summer.

I886.] 
134. Totanus solitarius. Solitary Sandpiper.-Common in spring and fall; stragglers sometimes remain in summer. Has been found breeding at Rutland, Vt., by Mr. Jenness Richardson (Brewer, Bull. Nutt. Orn. Club, III, I878, 197).

*135. Symphemia semipalmata. Willet.-Rare summer resident, sometimes breeding. More common in spring and fall. Dr. Brewer says he "met with it breeding on the small Island of Muskeget, near Nantucket (Water Birds of North America, I, I 884, 287).

[136.] Pavoncella pugnax. Ruff.-The only Massachusetts records of its occurrence appear to be Newburyport marshes, May 28, I87 (Brewster, Am. Nat., VI, I872, 306), and Chatham, Sept. I I, I880 (Plummer, Forest and Stream, Oct. 7, I880, I 86). Extralimital records include Long Island (several instances), Calais, Maine, several instances (Boardman, Proc. Bost. Soc. Nat. Hist., IX, 1862, 129), Upton, Maine (Brewester, Bull. Nutt. Orn. Club, I, 1876, 19), and in the interior as far west as Western Ontario (Morden and Saunders, Canad. Sportsm. and Nat., III, I883, 243) and Ohio (Wheaton, Bull. Nutt. Orn. Club, II, I877, 83).

*13\%. Bartramia longicauda. Bartramian Sandpiper.Not very common summer resident; abundant during migrations.

138. Tryngites subruficollis. Buff-Breasted Sandpiper. -Rather uncommon spring and autumn visitant.

*139. Actitis macularia. Spotted SANDPIPER.-Common summer resident.

140. Numenius longirostris. Long-Billed Curlew.-A not very common spring and autumn visitant.

141. Numenius hudsonicus. Hudsonian Curlew.-Spring and fall migrant; sometimes quite numerous, and generally more common than either of the other species of this genus.

142. Numenius borealis. Eskimo Curlew.-Rather uncommon spring and autumn migrant.

143. Charadrius squatarola. Black-Bellied Plover.Generally more or less common during spring and fall.

144. Charadrius dominicus. American Golden Plover.Common autumn migrant; very rare in spring (see Brewster, Bull. Nutt. Orn. Club, VIII, r883, r63.) 
*145. Egialitis vocifera. KilLDEer. - A not common summer resident.

146. Egialitis semipalmata. Semipalmated Plover.Abundant spring and autum ${ }_{A}$ visitant.

*14\%. Egialitis meloda. Piping Plover.--Common summer resident along the coast.

[147a.] Fgialitis meloda circumcincta. BeLted Piping Plover. - Probably of rare or casual occurrence, it having been taken on Long Island (Rockaway, April 30, 1873, Eagle, Bull.

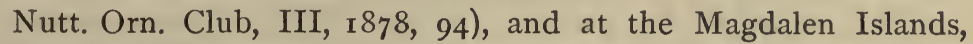
Gulf of St. Lawrence (Cory, Naturalist in the Magdalen Islands, I878, 6I). I am under the impression that I have seen a Massachusetts example.

[148.] Egialitis wilsonia. Wilson's Plover.-Accidental. Gurnet ("Conn."=Mass.), Aug. 20, 1877 (Coues, apud Fisk, Bull. Nutt. Orn. Club, VII, 1882, 59). There are several recent Long Island (N. Y.) records, and it has lately been taken in Nova Scotia (Goss, Auk, II, 22I).

149. Arenaria interpres. Turnstone.-Rather common spring and autumn visitant.

[150.] Hæmatopus palliatus. American Oyster-Catcher. - Now of merely accidental occurrence. The only recent explicit record is Chatham, April, 1885 (Brewester, Auk, II, 1885,384 ; Cahoon, same specimen, Orn. and Oöl., X, I885, I60). Formerly, doubtless, not uncommon.

$\because 151$. Colinus virginianus. Boв-white.-More or less common resident in most parts of the State.

[152.] Dendragapus canadensis. Canada Grouse.-Accidental. Only two recorded instances of its capfure, which are Gloucester, 185 I (Putnam, Proc. Essex Inst., I, 1856, 224); Roxbury, about 1865 (Allen, Am. Nat., III, I870, 636).

*153. Bonasa umbellus. Ruffed Grouse.-Common resident.

*154. Tympanuchus cupido. Prairie Hen.-Formerly common in various parts of the State, but long since extirpated, except on the Island of Martha's Vineyard, where they still exist I886.] 
in considerable numbers. (See Brewster, Auk II, I 885, 80-84.) Western birds have at different times been turned out in Barnstable and Berkshire Counties, where some, or their descendants, still survive. (See beyond, under "4. Introduced species.")

*155. Ectopistes migratorius. Passenger Pigeon.-Irregular summer resident, not generally common. Has greatly decreased in numbers during the last twenty to fifty years.

*156. Zenaidura macroura. Mourning Dove.-Common summer resident.

[15\%.] Cathartes aura. Turkey Vulture.-Accidental. Two were taken in the State in 1863 (Samuels, Agr. Mass., Secy's Rep. 1863 , App., p. xviii). Seen in Waltham, August, 1867 (Maynard, Nat. Guide, I870, I37*).

There are numerous Connecticut records (see Merriam, Rev. Bds. Conn. 1877, 91; Sage, Orn. and Oöl., VII, I4I), and it has been recorded from Hampton Falls, N. H. (Cory, Bull. Nutt. Orn. Club, VII, I882, I84). Maine records are Calais (Verrill, Proc. Bost. Soc. Nat. Hist., IX., I 862, I 22 ), Standish, Cumberland County (Smith, Forest and Stream, XX, No. 2, Feb. 8, 1883, 26), Freyburg, (Gushee, ibid., XX, 1883, 245), Buxton (Brown, Proc. Portland Soc. Nat. Hist., I882), and Grand Menan (Moses, Forest and Stream, V, No. 3, Aug. 26, 1875).

[158.] Catharista atrata. Black Vulture.-Accidental. Swampscott, November, I 850 (Putnam, Proc. Essex Inst., I, I856, 223); Gloucester, Sept. 28, I863 (Allen, ibid., IV., I864, 8I); Hudson (Allen, Am. Nat., III, I870, 646). Maine records are Calais (Boardman, Am. Nat., III, I869, 498), and Campobello Island, August, 1879 (Deane, Bull. Nutt. Orn. Club, V, I880, 63). A Vermont record is Woodbury, July, 1884 (Graham, Random Notes on Nat. Hist., I, I884, No. 9, 4).

[159.] Elanoides forficatus. Swallow-TAILED Kite.Accidental. Seen at Whately, about I868 (Allen, Am. Nat., III, I870, 645); taken at West Newberry, Sept. I882 (Coues, apud Nerecomb, Bull. Nutt. Orn. Club, VIII, I883, 6r). Dr. Merriam

*Dr. Coues says at the end of his account of this species in "New England Bird Life" (II, 1883, 137), "and Mr. Purdie's manuscript makes us aware of two later Massachusetts instances." Mr. Purdie writes me that "Massachusetts" should read "Maine," Dr. Coues having misunderstood his note. These two Maine cases are on the authority of Mr. Boardman, and appear to have not yet been published. 
gives it as "a rare straggler from the south" in Connecticut (Rev. Bds. Conn., 1877,76$)$, and there are Long Island records for 1837 (Giraud, Birds of Long Island, I844, I3) and 1845 (Berier, Bull. Nutt. Orn. Club, VI, I88 I, I26). (An erroneous record for Maine is given in "Forest and Stream," XXI, I884, No. 19, 563; corrected, l. c., No. 24,464 .)

*160. Circus hudsonius. Marsh Hawk.-Common summer resident.

*161. Accipiter velox. Sharp-Shinned Hawk.-Rather common summer resident. Has also been taken in winter $(F . H$. $C$ [arpenter], Orn. and Oöl., XI, r 886, 25; Allen, Auk, II, 3 I I).

*162. Accipiter cooperi. Cooper's Hawk.-Common summer resident ; of occasional occurrence in winter.

163. Accipiter atricapillus. American Goshawk.- Rather frequent winter visitant. Has been seen in summer, and perhaps occasionally breeds in the western part of the State.

*164. Buteo borealis. Red-Tailed Hawk.-A rather common resident, but most numerous in fall and spring.

*165. Buteo lineatus. Red-Shouldered Hawk.-Common resident; most abundant in fall and spring.

[166.] Buteo swainsoni. Swainson's Hawk. - Accidental. Only two instances of its capture thus far recorded-Salem, winter of 1871-72 (Allen, Bull. Essex Inst., X, I878, 22); Wayland, Sept. I2, I876 (Brewster, Bull. Nutt. Orn. Club, III, I878, 39).

*16\%. Buteo latissimus. Broad-winged HAwk.-Rather rare summer resident.

168. Archibuteo lagopus sancti-johannis. A M E IC A N RoUGH-LEGGED HAwK.--Rather common winter visitant, but of somewhat local distribution.

*169. Aquila chrysaëtos. Golden Eagle.-Very rare winter visitant. Recent records of its capture are Munson, Nov. I864; Deerfield, Dec. I4, I 865 ; W'estfield, three specimens, I 866 (Allen, Am. Nat., III, -Dee.-1869) ; Fairhaven, Nov. 2 I, I873 (Allen, Bull. Essex Inst., X, I878, 22). This specimen was sent in the flesh by Captain Charles Bryant to the Museum of Comparative Zoölogy, where it is now preserved. Also Williamstown, I886.] 
and said to breed on Graylock (Brezuster, Auk, I, I 884, Iо). Mr. E. H. Forbush informs me of a specimen taken in Paxton, Worcester County, October 22, I884.

*170. Haliaetus leucocephalus. BaLd EAGLE.-Rare resident.

[1\%1.] Falco rusticolus. GRay Gyrfalcon.-Of rare or accidental occurrence in winter. There are various records.

[171a.] Falco rusticolus obsoletus. Black GRYfalcon.Casual or accidental. Breed's Island, Boston Harbor, Oct. I 876 (Cory, Bull. Nutt. Orn. Club, II, I877, 27); Essex County (Purdie, Bull. Nutt. Orn. Club, IV, I879, I89); Stowe, I88 I (Brewster, ibid., VIII, 1883 , I84). There are also Vermont, Maine, Rhode Island and Long Island records. (For New England records of Gryfalcons see Purdie, in Stearns and Coues's "New England Bird Life," II, r883, I ro, I I ; Jencks, Auk, I, r 884, 94.)

*17\%. Falco peregrimus anatum. Duck HAwk.-Rare resident; more common in winter than in summer, and along the coast than in the interior. Mount Tom and Sugar Loaf Mountain are well known as among its breeding places, and it doubtless breeds elsewhere in the western part of the State, as it does at various localities in Connecticut and in the Helderberg Mountains near Albany, N. Y. (Lintner, Auk, I, r884, 39r).

173. Falco columbarius. Pigeon Hawk.-Rather rare, occurring chiefly in spring, fall, and winter.

174. Falco sparverius. American Sparrow Hawk.-More or less common resident; most numerous, however, in spring and fall.

175. Pandion haliaëtus carolinensis. American Osprey.Occasional summer visitant. Formerly bred in the State, but now nests here very rarely. Mr. F. H. C[arpenter] refers to a colony of "about forty nests" on Palmer River, near Rehoboth (Orn. and Oöl., IX, г 884, го०).

[176.] Strix pratincola. American BARN OwL.-Very rare or accidental. Only two specimens as yet known to have been taken in the State-one at Springfield, May, i 868 (Allen, Proc. Essex Inst., VД, I868, 312); the other at Lynn, in 1865 (Allen, Am. Nat., III, I870, 646). 
*17\%. Asio wilsonianus. American Long-eared OwlA not common resident.

*178. Asio accipitrinus. Short-eared OWL.-Rather common resident. .

*179. Syrnium nebulosum. Barred Owl.-Rather common resident.

[180.] Ulula cinerea. Great Gray Owl.-Accidental or very rare winter visitor. Recent records are Salem, Nov. Io, I866 (Allen, Am. Nat., III, Jan. I870, 570); Lynn, 1872 (Brewer, Hist. N. Am. Bds., III, 1874, 32); Agawam, Feb. 25, I883 (Allen, Bull. Nutt. Orn. Club, VIII, 1883, I23). A recent Rhode Island record is Wickford, March 25, 1883 (Jencks, Bull. Nutt. Orn. Club, VIII, I883, 183). (For references to some earlier records see Allen, Proc. Essex Inst., IV, 1864, 81; Am. Nat., III, I870, 570; also Merriam, Rev. Bds. Conn., I877, 70.)

181. Nyctala tengmalmi richardsoni. Richardson's OwL.-Rare winter visitor. Recent records of its occurrence are Lynn, I863 (Allen, Am. Nat., III, I870, 646); Cambridge, Dec. r865 (Maynard, Nat. Guide, 1870, 133); near Newton, Feb. 26, 1879 (Brewer, Proc. Bost. Soc. Nat. Hist., XX, 27I). It was taken near Providence, R. I., during winter of $1880-8 \mathrm{I}$ (Jencks, Bull. Nutt. Orn. Club, VI, I88I, I23), and Dec. I8, I882 (Jencks, ibid., VIII, 1883, I22); and at Hollis, N. H. (Fox, ibid., VIII, I883, 61).

*182. Nyctala acadica. SAw-whet OwL--Rather common and probably resident (see Deane, Bull. Nutt. Orn. Club, II, 84). Found breeding at Braintree, June 4, 1880, and five nearly fledged young taken (Francis, Bull. Nutt. Orn. Club, VI, 185).

*183. Megascops asio. Screech OWL-Common resident.

*184. Bubo virginianus. Great Horned Owl.-A not uncommon resident.

185. Nyctea nyctea. Snowy OwL.-A more or less regular winter visitant. Very abundant during the winter of $1876-77$ (see Deane, Bull. Nutt. Orn. Club, II, I877, 9).

[186.] Surmia ulula caparoch. American Hawk Owl.-Very rare winter visitor in most parts of the State; perhaps of rather frequent occurrence in the more ellevated parts of Berkshire I886.] 
County. (See Allen, Am. Nat., III, I86 6 , 569.) There is a recent record of a specimen taken in Framingham in January, I860 (Browne, Auk, II, I885, 220), and of another taken at Chatham during the winter of $\mathbf{1 8 8} 3-84$ (Allen, Auk, II, I885, 383). There was quite an incursion of these birds into northern New England in the autumn of 1884 (Brezester, Auk, II, I885, I08), and one is reported as having been taken near Lynn ( $F . B . W[$ ebster], Orn. and Ö̈l., X, 1885, 32).

[187.] Speotyto cunicularia hypogara. BURrowing OwL.Accidental. Newburyport, May 4, I875 (Deane, Rod and Gun, VI, 97, May 15, I875). This specimen is now in the Museum of Comparative Zoölogy at Cambridge.

*188. Coccyzus americanus. Yellow-billed Cuckoo.Rather frequent summer resident. Somewhat irregularly dispersed, and very variable in respect to numbers in different years.

*189. Coccyzus erythrophthalmus. BlaCk-Billed Cuckoo. - Common summer resident.

*190. Ceryle alcyon. Belted Kingrisher.-Common summer resident. Occasionally met with in winter.

*191. Dryobates villosus. Hairy Woodpecker.-A not

- common resident. More numerous in winter than in summer, when it is generally rare, especially in the eastern part of the State.

*192. Dryobates pubescens. Downy Woodpecker.-Rather common resident.

193. Picoides arcticus. Arctic Three-toed Woodpecker. -Very rare winter visitor. Recent records are: Middlesex County, fall of I87 I (Purdie, Am. Nat., VII, r873, 693); Hyde Park, last of September, 1878 (Deane, Bull. Nutt. Orn. Club, V, Jan. I880, 56); near Dorchester, Aug. I I, I883 (Stearns, Forest and Stream, XXI, No. 24, Jan. Iо, I884, 474); Plymouth, Dec. I7, I880 (Brewester, Bull. Nutt. Orn. Club, VI, I881, I82); West Medford, Oct. 16, 1883 (Bridge, Journ. Boston Zoöl. Soc., III, Jan. I884, I7); Lynn, winter of I860-6I (Brewester, Bull. Nutt. Orn. Club, VIII, April, r883, r22); Woburn and Holbrook, Oct. I 883 (Brewster, Auk, I, Jan. I884, 93). 
[194.] Picoides americamus. American Three-toed WoodPECKER. - Very rare or accidental winter visitor. A recent record is Lynn, winter of I860-6I (Brewester, Bull. Nutt. Orn. Club, VIII, April, I883, I22) -three specimens, two of them previously recorded (Allen, Am. Nat., III, r869, 572).

*195. Sphyrapicus varius. Yellow-bellied Sapsucker.Not very common in spring and fall; found occasionally in summer, and a few probably breed, more especially in Berkshire County, where birds with young were found by Mr. Brewster in June, I 883 (Auk, I, Jan. I884, I2). Marked also as breeding by Dr. Emmons.

*196. Ceophlœus pileatus. Pileated Woodpecker. Nearly or quite extirpated from most parts of the State, but still more or less frequent in Berkshire County, and of occasional occurrence in other well wooded portions of the State. A recent record for the eastern part of the State is Boston Highlands, July 20, $188_{3}$ (Bracket, Journ. Boston Zoöl. Soc., III, I884, I7). On its occurrence in Berkshire County see Brewster, Auk, I, Jan. I884, 9, I2.

*19\%. Melanerpes erythrocephalus. RED-HEADED WoodPECKER.-Rare summer resident, occasionally breeding. Most frequently observed in fall, and usually in immature plumage. It was unusually common about Boston, as well as in other parts of eastern New England, in the fall of r88I (Purdie, Bull. Nutt. Orn. Club, VII, Jan. 1882, 57).

[198.] Melanerpes carolinus. Red-bellied Woodpecker.A rare straggler. Observed at Springfield, May I3, I863 (Allen, Proc. Essex Inst., IV, I864, 53); taken at Newton, Nov. 25, 1880 (Plummer, Bull. Nutt. Orn. Club, VI, April, I88I, 120); and at Cohasset, May 28, I88I (Brezester, ibid., VI, July, I88I, I83). Also at Suffield, Conn., within a few miles of the Massachusetts line, July 30, 1874 (Merriam, Rev. Bds. Conn., 1877, 65). Given also by Emmons and Peabody, but their records were later discredited.

*199. Colaptes auratus. FLICKER.-Abundant summer resident. Occasionally seen in winter.

I886.] 
[200.] Antrostomus carolinensis. ChuCK-will's-widow.Accidental. One found dead in a barn in Revere, in December, I884 (Osgood, Auk, II, April, I885, 220). This specimen is now in the Cambridge Museum of Comparative Zoölogy.

*201. Antrostomus vociferus. Whip-Poor-Will.-Common summer resident.

*202. Chordeiles virginianus. Nighthawk.-Abundant summer resident.

*203. Chatura pelasgica. Chimney Swift. - Abundant summer resident.

*204. Trochilus colubris. Ruby-throated Hummingbird. -Common summer resident.

*205. Tyrannus tyramuus. KINGBIRD. - Common summer resident.

[206.] Tylannus dominicensis. Gray Kingbird. - Accidental. Taken in Lynn early in October, 1869 (Allen, Am. Nat., III, I870, 645).

*20\%. Myiarchus crinitus. Crested Flycatcher. - Rare summer resident.

*208. Sayornis phobe. PhEвe.-Common summer resident.

*209. Contopus borealis. Olive-sided Flycatcher. Rather uncommon summer resident; in general breeding sparingly, but commonly in Berkshire County (Brewster, Auk, I, Jan. I884, I5).

*210. Contopus virens. Wood PEweE.-Common summer resident.

*211. Empidonax flaviventris. Yellow-Bellied FlyCATCher.-Not uncommon in spring and fall. Breeds in Berkshire County (Brewster, Auk, I, 1884, I5).

*212. Emıidonax pusillus traillii. Traill's FlycatchER.-Chiefly spring and autumn visitant. Not common. A few remain in summer and breed. [This is Empidonax acadicus of my "Birds of Springfield "(Proc. Essex Inst., IV, 1864, 54), plus E. traillii of the same "List.]

*213. Empidonax minimus. Least Flycatcher. - Common summer resident. 
214. Otocoris alpestris. HORNED LARK.-Winter visitant, chiefly along the coast, where it is generally common and sometimes abundant.

*215. Cyanocitta cristata. Blue Jay.-Common throughthe year.

216. Corvus corax sinuatus. American Raven. - Very rare. Very few recorded instances of its capture within the State. A recent record is Williamstown, 1877 (Tenney, Am. Nat., XI, 243 ; Brezester, Auk, I, Jan. 1884, Io, foot-note). Frequent on the islands off the coast of Maine (Merrill, Bull. Nutt. Orn. Club, VI, 249). It has also been recorded from Brandon, Vt.

*21\%. Corvus americanus. American Crow. - Common resident.

*218. Dolichonyx oryzivorus. Boвolink.-Abundant summer resident.

*219. Molothrus ater. Cowbird.-Common summer resident. Has been taken in winter (Belmont, Spelman, Bull. Nutt. Orn. Club, VIII, I883, r21).

[220.] Xanthocephalus xanthocephalus. Yellow-HEaded BLACKBIRD.-Accidental. Two instances of its capture. First identified from the wings, tail, and foot of a specimen shot by Mr. Frank Sawyer in Watertown, Oct. 15, r869 (Allen, Am. Nat., III, I870, 636). According to Mr. N. Vickary, of Lynn, two specimens were shot at Eastham, Sept. 10, 1877, by Mr. Loud, of Salem, one of which was preserved (Allen, Bull. Essex Inst., X, I $878, \mathrm{I} 8)$.

*221. Agelaius phoniceus. Red-winged Blackbird.Common summer resident.

*222. Sturnella magna. Meadow Lark.-Common summer resident; a few sometimes remain in winter.

*223. Icterus spurius. OrChaRd ORIOLE.-Rare summer resident. More common in the Connecticut Valley than elsewhere in the State.

*224. Icterus galbula. Baltimore Oriole.-Abundant summer resident.

I 886.] 
225. Scolecophagus carolinus. Rusty BlackBird.-Rather common spring and autumn visitant.

*226. Quiscalus quiscula aneus. Bronzed Grackle.Common summer resident.

22\%. Pinicola enucleator. Pine Grosbeak.-Irregular winter visitant, occurring sometimes in abundance.

*228. Carpodacus purpureus. Purple Finch.-Rather common summer resident; a few probably remain at some localities during winter.

*229. Loxia curvirostra minor. American Crossbill.Irregular winter visitor, but a much more frequent and abundant one than the next species. A few often occur in summer, and occasionally breed (Browne, Auk, II, I885, 105), as they have been found to do on Long Island (Orn. and Oöl., VII, 68), in New Jersey (Forest and Stream, XXII, 302), and elsewhere as far south as Maryland (Auk, I, 292, and II, 379).

230. Loxia lencoptera. White-winged Crossbill.-Irregular and infrequent winter visitant.

231. Acanthis linaria. REDPoll.-An irregular but often abundant winter visitor.

231 $a$. Acanthis linaria rostrata. Greater RedPoll. With the preceding, but much less numerous. (See Brewster, Bull. Nutt. Orn. Club, VIII, April, I883, 95-99, where this form is referred to at length under the name Agiothus linaria holboelli.)

*232. Spinus tristis. American Goldfinch.-Common throughout the year, but of gregarious and nomadic habits in winter.

233. Spinus pinus. Pine Siskin.-Chiefly spring and autumn migrant; occasionally remains through the winter, and has been known to occur in summer. Marked as breeding by Dr. Emmons. Lu wh Breeding at Sing Sing, N. Y., May, 1883 (Fisher, Bull. Nutt. Orn. Club, VIII, I883, I80). Also at Rutland, Vt. (Science, III, 2 I6).

234. Plectrophenax nivalis. SNowflake. - Regular and rather common winter visitant.

235. Calcarius lapponicus. LAPLAND LongSPUR. - Winter visitant, mainly near the coast; not common. 
[236.] Calcarius ornatus. Chestnut-collared Longspur. -Accidental. Magnolia, near Gloucester, July 28, 1876 (Brewer, Bull. Nutt. Orn. Club, II, 1877,78$)$.

*23\%. Poocretes gramineus. Vesper Sparrow.--Abundant summer resident.

238. Ammodramus princeps. IPswich Sparrow.-Rather rare but regular winter visitant, occurring chiefly near the coast. Has been met with along the coast from Prince Edward's Island to Delaware.

*239. Ammodramus sandwichensis savanna. Savanna SPARROW.-Abundant summer resident along the coast; much less common in the interior.

*240. Ammodramus savannarum passerinus. GrasshopPER SPARROW.-Common and even abundant summer resident at favorable localities, especially in the Connecticut Valley and near the sea coast.

*241. Ammodramus henslowi. Henslow's Sparrow.Rare summer resident, of rather irregular distribution.

*242. Ammodramus caudacutus. Sharp-tailed Sparrow. -More or less common in the salt marshes along the coast, especially in those of Charles River.

242a. Ammodramus caudacutus nelsoni. Nelson's SparRow.-Occurs sparingly with the preceding in autumn (Henshaw, Auk, III, r886, 一),

243. Ammodramus maritimus. SEA-Side Sparrow.Rare or accidental in the salt marshes along the coast. Only one recent record of its capture in the State-Nahant, Aug. 1877

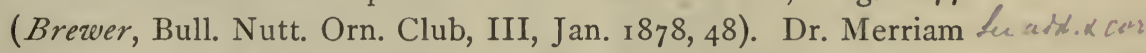
gives it as a common summer resident in the salt and brackish water marshes of Connecticut (Rev. Bds. Conn., I877, 38).

[244.] Chondestes grammacus. Lark Finch.-Accidental. Four recorded instances of its occurrence. Gloucester, about r845 (Putnam, Proc. Essex Inst., I, 1856, 224); Newtonville, Nov. 25, I 877 (Purdie, Bull. Nutt. Orn. Club, III, I878, 44); Magnolia, Aug. 29, I879 (Towensend, Bull. Nutt. Orn. Club, V, 53); I886.] 
Framingham, April, I 883 (Brozene, Bull. Nutt. Orn. Club, VIII, r883, r8r).

245. Zonotrichia leucophrys. WhITE-CROWNED SPARRow. -Rather rare spring and autumn migrant.

*246. Zonotrichia albicollis. White-throated SPARRow. -Abundant spring and autumn migrant. Breeds in Berkshire County (Emmons; see also Brewester, Auk, I, 1884, 15). Recorded as nesting in Framingham, in June, 1874 (Browne, Bull. Nutt. Orn. Club, V, r880, 52). Taken in winter (Jan. 7, 1882) in Cambridge (Lamb, Journ. Boston Zoöl. Soc., I, I882, 32 ).

24\%. Spizella monticola. TREE SPARROw.-Common winter visitant.

*248. Spizella socialis. ChIPPING SPARRow.-Abundant summer resident.

[249.] Spizella breweri. BREwer's SPARROW.-Accidental. Watertown, Dec. I5, I873 (Brewuster, Am. Nat., VIII, I874, 366).

*250. Spizella pusilla. Field Sparrow.-Common summer resident.

*251. Junco hyemalis. Slate-COLORED JunCo.-Mainly a spring and autumn visitant; a few are sometimes observed in winter. Breeds abundantly in the more elevated parts of Berkshire County. (See Auk, I, I884, I4.)

[251 $a$.] Junco hyemalis oregonus. OREGon Junco.-Accidental. Watertown, March 25, I 874 (Brewester, Bull. Nutt. Orn. Club, I, 1876, 19).

*252. Melospiza fasciata. Song Sparrow.-Abundant summer resident; a few sometimes remain in winter in sheltered localities.

253. Melospiza lincolni. Lincoln's $\mathrm{F}_{\mathrm{INCH}}$ - A rare or casual visitor in spring. Mr. E. I. Shores considers it as not rare at Suffield, Conn., where he believes it sometimes breeds. (See Merriam, Rev. Bds. Conn., I 877, 38.) It has also been reported as breeding at Otter Lake, Hamilton Co., N. Y. (Bagg, Bull. Nutt. Orn. Club, III, ז878, 197 ; ibid., VI, I882, 246).

*254. Melospiza georgiana. Swamp Sparrow.-A not very common summer resident, of rather local distribution. 
255. Passerella iliaca. Fox Sparrow. - Abundant spring and autumn migrant.

*256. Pipilo erythrophthalmus. TowheE. - Abundant summer resident.

[25\%.] Cardinalis cardinalis. Cardinal. - Accidental. Several instances of its occurrence recorded. A recent one is Woburn, Nov. 14, 1882 (Richards, Bull. Nutt. Orn. Club, VIII, 1883, 59). It has been taken as far north as Halifax, N. S. (Jones, Am. Nat., V, I871, I76), and is resident in small numbers in Central Park, New York City, in Brooklyn, and on Long Island, N. Y.

*258. Habia ludoviciana. Rose-breasted Grosbeak. Common summer resident.

[259.] Guiraca cxulea. Blue Grosbeak. - Accidental. Taken at Brookline, May 29, I880, by Mr. Gordon Plummer (Allen, Bull. Nutt. Orn. Club, V, 1880, 184). Has also been taken at Grand Menan and Calais, Maine (Boardman, Proc. Bost. Soc. Nat. Hist., IX, I862, 127).

*260. Passerina cyanea. Indigo Bunting.-Common summer resident.

*261. Spiza americana. Black-throated Bunting. Very rare summer resident. Not generally distributed, but of rather frequent occurrence at some localities in the eastern part of the State. (See Purdie, Bull. Nutt. Orn. Club, III, I878, 45; Brewer, ibid., III, 1878 , 190 ; Deane, ibid., IV, 1879, I22.) Has been taken as far north as Penobscot Bay, Maine (Townsend, Auk, II, r885, I06).

[262.] Calamospiza melamocorys. Lark Bunting.-Accidental. One instance of its capture-Lynn, Dec. 5, 1877, taken by Mr. N. Vickary (Allen, Bull. Nutt. Orn. Club, III, I878, 48).

[263.] Piranga ludoviciana. Western Tanager.-Accidental. A single specimen was taken alive in Salem, Jan. 20, 1878 (Brewer, Forest and Stream, X, 95, March I4, I878; Allen, Bull. Essex Inst., X, 1878, 37, where for "Lynn" read Salem).

*264. Piranga erythromelas. Scarlet Tanager.-Common summer resident.

I886.] 
[265.] Piranga rubra. Summer Redbird.-Accidental summer visitor. Several instances of its capture are on record. The most recent is Swampscott, June, I 866 (Allen, Bull. Essex Inst., $\mathrm{X}, \mathbf{1 8 7 8 ,}$ 15). Taken at Grand Menan, May, i88I (Batchelder, Bull. Nutt. Orn. Club, VII, I882, 249).

*266. Progme subis. Purple Martin.-Common summer resident.

*26\%. Petrochelidon lunifrons. Cliff Swallow.-Common summer resident.

*268. Chelidon erythrogaster. BARN Swallow.-Common summer resident.

*269. Tachycineta bicolor. TRee Swallow.-Common summer resident.

*270. Clivicola riparia. Bank Swallow,-Common summer resident.

[271.] Ampelis garmulus. NORThern WAX-Wing.-Accidental in winter. The latest record is Lynn, Feb. 18,1877 (Allen, Bull. Essex Inst., X, I878, 15).

*272. Ampelis cedrorum. Cedar Wax-wing. - Common summer resident ; frequently seen in winter in roving flocks, and at localities where it finds a good supply of food.

273. Lanius borealis. Great Northern Shrike.-Rather common winter visitant.

274. Lanius Indovicianus excubitoroides. WhITE-RUMPED SHRIKE.-Casual in migrations. Recent records of its occurrence are West Newton, Oct. 2 I, 1872 (Purdie, Am. Nat., VII, I873, II5); Newtonville, 1874 (Maynard, Am. Sportsman, V, 3I3, Feb. I3, r875); Lynn, Nov. 1877 (Allen, Bull. Essex Inst., X, I878, I5); Brookline, Feb. 1879 (Brewester, Bull. Nutt. Orn. Club, VI, I88I, 55). More common in portions of Northern New England, where it breeds, as at Bangor, Me. (Brewer, Bull. Nutt. Orn. Club, IV, 1879, II9; Purdie, ibid., IV, I879, r86; Merrill, ibid., VI, r88r, 250), and Rutland, Vt. (Brewer, ibid., IV, I879, Ir9).

*275. Vireo olivaceus. RED-EYed Vireo. Abundant summer resident. 


\section{American Museum of Natural History. 255}

276. Vireo philadelphicus. Philadelphia Vireo.-Very rare. There are but few records of its occurrence in the State, as follows: Cambridge, Sept. 7, I875 (Brewester, Bull. Nutt. Orn. Club, I, I876, I9); Magnolia, Sept. I8, r879 (Townsend, ibid., V, I 880, 53); Brookline, Sept. I880? (Brezester, ibid., VI, I88 I, 5\$). It has been found to be a not very uncommon summer resident in northern Maine (see especially Brewster, Bull. Nutt. Orn. Club, $\mathrm{V}, \mathrm{x} 880, \mathrm{x}-7$ ).

*27\%. Vireo gilvus. Warbling Vireo.-Common summer resident.

*278. Vireo flavifions. Yellow-throated Vireo.-Rather common summer resident.

*279. Vireo solitarius. Blue-headed Vireo.-Common spring and autumn migrant; a few stay through the summer and breed.

*280, Vireo noveboracensis. White-Eyed Vireo.-More or less common summer resident at certain localities.

*281. Muiotilta varia. Black-And-white Creeper.-Common summer resident.

[282.] Protonotaria citrea. Prothonotary Warbler.Accidental. Concord, May 9, 1886 (Brewster, Auk, III, r886, 4ro). Long since introduced into the lists of New England birds on the basis of its capture at or near Calais, Me. (Verrill, Proc. Bost. Soc. Nat. Hist., IX, I863, 234). The specimen seems to have been captured, however, at St. Stephen's, just within the borders of New Brunswick (Baird, Brewer, and Ridgway, Hist. N. Am. Birds, I, I $874,184, \mathrm{I} 86$ ), though still sometimes attributed to Maine (Stearns and Cones, New England Bird Life, I, I88I, I Io; Simith, Forest and Stream, XIX, No. 23, Jan. 4, I883, 445). One was taken at South Kingstown, R. I., April 2r, I884 (Jencks, Random Notes on Nat. Hist., I, I884, No. 5, 8, and No. 6, 8). Its usual northern limit along the Atlantic coast, however, seems to be the vicinity of Philadelphia.

[283.] Helmitherus vermivorus. WORM-Eating Warbler. -A rare or accidental straggler from the south. The only record of its capture in the State is Cambridge, Sept. I9, I $88 \mathbf{I}$ I 886.] 
(Spelman, Bull. Nutt. Orn. Club, VI, I881, 246). Mr. Stearns reports having seen the species at Easthampton (New England Bird Life, I, I88I, III). Of quite frequent occurrence in Southern Connecticut, where it has been found breeding ( $W$ oolsey, Bull. Nutt. Orn. Club, V, r880, r 6 ; Sage, Auk, II, I885, 305).

[284.] Helminthophila pinus. Blue-winged Warbler.Rare straggler from the south. The two Massachusetts records are Dedham, about 1854 (Cabot, Proc. Bost. Soc. Nat. Hist., VI, 386-specimen still extant in the Society's collection), and West Roxbury, May I 7, I878 (Deane, Bull. Nutt. Orn. Club, III, 1878,188 ). Of frequent occurrence in Southern Connecticut, where it is recorded as regularly breeding, probably in considerable numbers (see Merriam, Rev. Bds. Conn., I877, 14 ; Stearns and Coues, New England Bird Life, I, I881, I I2;Averill, Orn. and Oöl., IX, ז884, i I I).

*285. Helminthophila chrysoptera. Golden-winged WarBLER.-Summer resident. Not generally common, but more or less frequent at some localities.

*286. Helminthophila ruficapilla. Nashville Warbler.Common summer resident.

[28\%.] Helminthophila celata. ORANGE-CROwNED WARBLER.-Rare or accidental. Only three instances of its capture thus far on record: Springfield, May 15, 1883 (Allen, Proc. Essex Inst., IV, $\mathbf{1 8 6 4}$, 60) ; Lynn, Jan. I, 1875 (Brewer, Proc. Bost. Soc. Nat. Hist., XVII, 439); Concord, Oct. 2, I 876 (Brewster, Bull. Nutt. Orn. Club, I, I876, 94). The only other New England records are Hollis, N. H., May I6, I876 (Fox, Forest and Stream, VI, 354) ; Cranston, R. I., (Purdie, Bull. Nutt. Orn. Club, II, 1877, 21). The Isles of Shoals record (Murdoch, ibid., III, I878, 96), proved erroneous (Brewster, ibid., VII, I882, 53).

288. Helminthophila peregrina. Tennessee Warbler.Rare spring and autumn migrant.

*289. Compsothlypis americana. BLUE YeLLOW-BACKeD WARBLER.- - Rather common summer resident.

290. Dendroica tigrina. CAPE MAY WARBLER.-Rather rare spring and autumn migrant. 
*291. Dendroica restiva. Yellow Warbler.-Abundant summer resident.

*292. Dendroica cerulescens. Black-throated Blue WARBLER.-Chiefly a spring and fall migrant. It breeds, however, in Berkshire County (Brezester, Auk, I, I884, I 2, I5), and has been observed in summer in other portions of the State. Breeds also in the Catskills (Trippe, Am. Nat., VI, I872, 47), and has been found nesting in Connecticut ( Jones, Bull. Nutt. Orn. Club, I, ı 876, ı г ; Orn. and Oöl., VI, I881, 49 ; IX, І884, 30, 31).

293. Dendroica coronata. Yellow-RUMPed Warbler.Abundant spring and autumn migrant. A few known to winter on Cape Cod. May breed in portions of Berkshire County, as Mr. Jenness Richardson informs it does on Killington Mountain, near Rutland, Vt., and also on the island in Lake Bombazinelocalities within about fifty miles of the Massachusetts line.

[294.] Dendroica auduboni. Audubon's Warbler.-Accidental. Cambridge, Mass., Nov. 15, 1876 (Frazar, Bull. Nutt. Orn. Club, II, I877, 27).

*295. Dendroica maculosa. Black-AND-yellow Warbler. - Common spring and autumn migrant. Breeds in the higher parts of Berkshire County (Brezester, Auk, I, I884, II, 13), and has been observed a few times elsewhere in the State in summer.

*296. Dendroica pennsylvanica. Chestnut-Sided WarBLER.-Common summer resident.

297. Dendroica castanea. Bay-breasted Warbler.Spring and autumn migrant, varying greatly in abundance in different years.

298. Dendroica striata. Black-Poll Warbler.-Abundant spring and autumn migrant. Mr. Jenness Richardson informs me that it is a common summer resident about Castleton, Vt.

*299. Dendroica blackurnir. Black burnian Warbler. Common spring and autumn visitant, some remaining through the summer. Breeds in Berkshire County (Brezuster, Auk, I, I 884, I5).

[300.] Dendroica dominica. Yellow-throated Warbler. -A casual or accidental visitor. The only Massachusetts record is I886.] 
Dedham, about 1868 (Purdie, Bull. Nutt. Orn. Club, III, 1878, 146). It is recorded as an accidental visitor to Connecticut (Merriam, Rev. Bds. Conn., 1877, 17).

*301. Dendroica virens. Black-throated Green WarBLER.-Common summer resident.

*302. Dendroica vigorsii. Pine Warbler.-Common summer resident. Occasionally stays in winter (Framingham, Hogg, Journ. Boston Zoöl. Soc., I, 25 ; Duxbury, Dec. 1882, Brewster, Bull. Nutt. Orn. Club, VIII, I883, r20).

[303.] Dendroica palmarum. Palm Warbler. - Rare. Brookline, Oct., I 878 (Deane, Bull. Nutt. Orn. Club, IV, I879, 60, I86) ; Cambridge, Sept. I3, r880, and Belmont, Sept. 7, I88 I (Spelman, ibid., VII, 1882,54 ), and Sept. 29, 1883 (Lamb, Journ. Boston Zoöl. Soc., II, I883, 55).

303a. Dendroica palmarum hypochrysea. Yellow Palm WARBLER.-Abundant spring and autumn migrant; a few have been observed at favorable localities in winter.

*304. Dendroica discolor. Prajrie Warbler.-Common summer resident near the seaboard; less common in the interior.

*305. Seiurus aurocapillus.-Golden-Crowned Thrush.Abundant summer resident.

*306. Seiurus noveboracensis. WATER-THRUSH.--Rather common spring and autumn migrant. Some remain in summer, and it is recorded as breeding near Boston (Brewer, Hist. N. Am. Birds, I, 1874, 285).

[30\%.] Seiurus motacilla. Louisiana Water-THRUSH.Rare or accidental. One record of its capture (Mount Tom, April 28, I 869, Allen, Am. Nat., III, I870, 5\$7). It has been found breeding near Norwich, Conn. (Ingersoll, Am. Nat., VIII, 238), and at Saybrook in the same State (Sage, Orn. and Oöl., VII, I882, r45). Merriam gives it as "not rare in Southern Connecticut, where it breeds regularly, and probably in considerable numbers" (Rev. Bds. Conn., I877, 20). It has been taken also at Lake George, N. Y., May r6, I88I (Fisher, Bull. Nutt. Orn. Club, VI, r881, 245), and in Rhode Island (Deane, ibid., V, I880, Ir6; Jencks, Orn. and Oöl., VII, I882, I I4). 
308. Geothlypis agilis. Connecticut Warbler.-A very rare spring but not uncommon fall migrant; sometimes abundant in autumn in the vicinity of Cambridge. Probably more common in other parts of the State at that season than is generally supposed. Spring records are : Readville, May 24, I883 (Maynard, Journ. Boston Zoöl. Soc., II, r883, 43) ; Ashland, five specimens, spring, 1883 and $\mathrm{r} 884$ (Castle, Orn. and Oöl., IX, ז884, 75). Erroneous spring records for New England are New Haven, Conn. (Woolsey, Bull. Nutt. Orn. Club, V, ז880, I17); Bangor, Maine (Merrill, Bull. Nutt. Orn. Club, II, I877-corrected, Merrill, Auk, III, 1886, 4I3).

*309. Geothlypis philadelphia. Mourning Warbler.Rare spring and autumn migrant, in most parts of the State, but a summer resident, breeding numerously, in the higher portions of Berkshire County (Brezester, Auk, I, 1884, I4, I5).

*310. Geothlypis trichas. Marvland Yellow-throat.Abundant summer resident.

*311. Icteria virens. Yellow-Breasted Chat.-Rare summer resident. There are records of its nesting in various parts of the State, particularly in Essex County, where it is locally frequent.

[312.] Sylvania mitrata. Hooded Warbler.-Accidental or casual. The only authentic record is Brookline, June 25, I879 (Deane, Bull. Nutt. Orn. Club, V, 1880, Ir7). Not uncommon and breeding about Saybrook, in Southern Connecticut (Purdie, Am. Nat., VII, I873, 692 ; Bull. Nutt. Orn. Club, I, I876, 73 ; ibid., II, 1877, 21 ; Clark, Orn. and Oöl., VI, 1882, 9, 102).

313. Sylvania pusilla. Wilson's WARBLeR.-Rather rare spring and autumn migrant.

*314. Sylvania canadensis. Canadian Warbler.-Common spring and autumn migrant. Occasionally seen in summer, and breeds commonly in Berkshire County (Brezuster, Auk, I, $1884,9,15)$. Also recorded as breeding in Essex County (Brenever, Bull. Nutt. Orn. Club, III, 1878, 139 ).

*315. Setophaga ruticilla. American Redstart.-Rather common summer resident.

I886.] 
316. Anthus pensilvanicus. American Pipit.-Spring and autumn visitant, in small flocks. Has been taken in June at Swampscott (Brewer, Bull. Nutt. Orn. Club, III, I878, I94).

*31\%. Mimus polyglottos. Mockingbird.-Rare summer visitant, occasionally breeding, particularly in the Connecticut Valley. Also recorded as breeding in Arlington, near Boston (Townsend, Auk, I, I884, 192). The Mockingbird is given as a "rare summer visitant" to Connecticut (Merriam, Rev. Bds. Conn., 1877,7$)$, and is recorded as breeding repeatedly near Jewett City (Prior, Orn. and Oöl., IX, I884, I I5).

*318. Galeoscoptes carolinensis. CAT-BIRD.-Abundant summer resident.

*319. Harporhynchus rufus. Brown Thrasher.-Abundant summer resident.

[320.] Thryothorus ludovicianus. Carolina Wren.-Rare. Reported as occurring in Roxbury, in the summer of 1877 (Minot, Bull. Nutt. Orn. Club, I, I876, 76 ; Land Birds and Game Birds of New England, 1877,74$)$. A specimen was taken in Lynn, July 6, I 878 (Brewer, Bull. Nutt. Orn. Club, III, I 878, I93), and in Brookline, Nov. 4, I883 (Cory, Auk, I, I884, 9I). It has been taken at Rye Beach, N. H. (Spelman, Bull. Nutt. Orn. Club, VI, 188r, 54), and there are various recent records for Connecticut, Rhode Island, Long Island, and the vicinity of New York City.

*321. Troglodytes aëdon. House Wren.--Rather common summer resident.

*322. Troglodytes hiemalis. Winter Wren.-Winter visitant ; not common. Breeds in the higher mountainous portions of Berkshire County (Brezwster, Auk, I, I884, I5, etc.). It is also recorded as breeding at Lynn (Brewster, Bull. Nutt. Orn. Club, VIII, I 883 , I I9).

*323. Cistothorus stellaris. Short-BILled MARSH Wren.Locally common.

*324. Cistothorus palustris. Long-billed Marsh Wren. -Common, like the preceding, at favorable localities. 
*3\%5. Certhia familiaris americama. BRown CREEPER.Resident, occasionally breeding, but most numerous in spring, autumn, and winter.

*326. Sitta carolinensis. White-breasted Nuthatch.Rather common resident.

*39\%. Sitta canadensis. Red-breasted Nuthatch.-Winter visitant. Not generally common. The supposed instance of its breeding "on the ground, in Roxbury," May, 1877 (recorded in Am. Nat., XI, ${ }^{65}$ ), proves to have been a mistake, the eggs taken being not those of that species. Mr. Brewster reports it as breeding in Berkshire County (Auk, I, 1884, I5).

*328. Parus atricapillus. Chickadee.-Common resident.

[329.] Parus hudsonicus. Hudsonian Chickadee.-Accidental. The records are Concord, Oct. 30, 1870 (Brewester, Am. Nat., VI, 1872,306$)$ and Oct. 7 , I880 (Brewester, Bull. Nutt. Orn. Club, VI, I88I, 54); Cambridge, Dec. 3I, I880 (Spelman, Bull. Nutt. Orn. Club, VI, I88I, I I4); Quincy, March 14, I885 (Orn. and Oöl., X, 1885, 64). It was also given as a bird of the State by Peabody (Rep. Orn. Mass., I839, 402). Its capture at Smithfield, R. I. ( Jencks, Bull. Nutt. Orn. Club, VI, I88r, 54), is also of interest in this connection.

330. Regulus satrapa. Golden-crowned Kinglet.-Chiefly a winter visitant, occurring in variable abundance in different years, but usually is more or less common. Probably breeds in portions of Berkshire County, as it has been reported to do in the Catskills (Trippe, Am. Nat., VI, 1872, 47).

331. Regulus calendula. Ruby-crowned Kinglet.Abundant spring and autumn visitant.

[332.] Polioptila cierulea. Blue-gray Gratcatcher.Accidental or casual. There are, however, several records of its occurrence, as follows: Chatham, Nov. I8, 1877 (Deane, Bull. Nutt. Orn. Club, III, I878, 45); Falmouth, Dec. 18, I877 (Brewer, ibid., III, 1878, 146); Osterville, Cape Cod, Sept. 26, 1879 (Brewer, Proc. Bost. Soc. Nat. Hist., XX, 1879, 264); Magnolia, Aug. 27, 1879 (Deane, Bull. Nutt. Orn. Club, V, 1880, 47). It has been taken at Cape Elizabeth, Me. (Brown, ibid., V, I880, I 886.] 
236), and there are several recent instances of its capture near Providence, R. I. (Purdie, ibid., II, I877, 20), and in Connecticut (Merriam, Rev. Bds. Conn., I877, 8; Sage, Bull. Nutt. Orn. Club, VIII, I883, I79; Auk, III, I886, -).

*333. Turdus mustelinus. Wood Thrush.-Common summer visitant, except in the higher portions of Berkshire County.

*334. Turdus fuscescens. Wilson's Thrush.-Common summer resident.

335. Turdus aliciae. Gray-Cheeked Thrush.-Common spring and fall migrant.

335a. Turdus alicia bicknelli. Bicknell's Thrush."Regular and rather common spring and fall migrant.... Some seasons it is more numerous than the true alicice" (Brezester, in lit.). First recorded from Massachusetts by Mr. Brewster in I $88_{3}$ (Bull. Nutt. Orn. Club, VIII, I883, I 7 ).

*336. Turdus ustulatus swainsonii. Olive-Backed Thrush. -Common spring and autumn migrant. Probably breeds in portions of Berkshire County, where Mr. Brewster found it common in June, I883 (Auk, I, I884, I2, I5).

*33\%. Turdus aonalaschka pallasii. Hermit Thrush.Spring and fall migrant, except in the mountainous portions of the State west of the Connecticut Valley, where it is a common summer resident; also occasionally breeds in other parts of the State, notably in Barnstable County, in parts of which it is a not uncommon summer bird.

*338. Merula migratoria. American Robin.-Abundant summer resident; a few remain during winter at favorable localities.

[339.] Hesperocichla navia. VARIEd Thrush.-Accidental. As yet the only authentic record of its occurrence is its capture at Ipswich, in December, I 864 (Allen, Proc. Essex Inst., V, I868, 312; Am. Nat., III, Jan. I870, 572 ; see further, on its supposed earlier occurrence in Massachusetts, Proc. Essex Inst., IV, 1864,82 ).

*340. Sialia sialis. BlUEBIRD.-Abundant summer resident. 


\section{II.-EXTIRPATED SPECIES.}

1. Plantus impennis. Great Auk.-The former existence of this species in Massachusetts is attested by the occurrence of its bones in the Indian shell-heaps of the coast, particularly at Ipswich, and there are also unquestionable allusions to its presence on Cape Cod at the time the coast was explored by Gosnold in 1602 (see Bull. Nutt. Orn. Club, I, 1876, 59).

2. Grus americana. Whooping Crane.-This species was given by Emmons in 1833 as a rare but regular visitant, but there is no later record of its occurrence. It unquestionably occurred here at the time of the first settlement of the country, in common with the following species.

3. Grus mexicana. Sandhill Crane. - Unquestionably more or less abundant two hundred years ago (see Bull. Nutt. Orn. Club, I, 1876,58 ), but there is no recent record of its occurrence.

4. Meleagris galloparo. Wild Turkev.-Well known to have been a common species in Southern New England for a long time subsequent to the first settlement of this part of the country (see Bull. Nutt. Orn. Club, I, I 876, 55), but long since ceased to exist here in a wild state. Considered as nearly extinct by Emmons in 1833 , but said by Hitchcock to be at that time "frequently met with on Mount Holyoke" (Rep. Geol. Mass., etc., I833, 549).

Other species virtually extirpated, are the Prairie Hen (Tympanuchus cupido), now restricted to Martha's Vineyard, where a few representatives of this formerly rather common species still exist (see antè, p. 24I); the Whistling Swan (Olor columbianus), now only a rare straggler, and probably also the Trumpeter Swan (Olor buccinator). To these may doubtless be added the Labrador or Pied Duck (Camptolaimus labradorius). (See Rowley, Orn. Miscel., pt. VI, I877, 205-333; also Bull. Nutt. Orn. Club, III, 1878,79 ). 


\section{III.-SPECIES OF PROBABLE OCCURRENCE.}

Of the following list of nineteen species, the greater part have been included in various former lists of the birds of Massachusetts, but generally on inferential evidence, or on erroneous identification. About one-fourth of them have been taken within a few miles of the southern boundary of the State, and others, from their known general range, must evidently occur at rare intervals. At least one-half of the species named below have already been taken in adjoining States at points not far from the Massachusetts line.

1. Lams kumlieni. Kumlien's Gull.-As several specimens of this recently described species have been taken near the eastern coast of Maine (Grand Menan and Bay of Fundy), and one at Troy, N. Y., it may reasonably be expected to occur as a straggler to the coast of Massachusetts.

2. Procellaria pelagica. Stormy Petrel.-This species was formerly included as a bird of Massachusetts, but there seems to be no positive record of its occurrence south of the Newfoundland Banks. Its capture off the New England coast, as far south even as Massachusetts, would not be surprising, since at present our off-shore birds are by no means well-known.

3. Fregata aquila. MAN-O'-WAR BIRD.-As this southern species has been taken on Faulkner's Island, Conn. (Grinnell, Am. Nat., IX, $\mathrm{x} 865,470$ ), at Booth Bay, Maine (Purdie, in Stearns and Coues's New England Bird Life, II, I883, 342), and in Nova Scotia (Deane, Bull. Nutt. Orn. Club, IV, I 879,64 ), it may be entered in the present list as a possible accidental visitor to Massachusetts.

4. Anas penelope. Widgeon.-This European species, formerly given as a bird of Massachusetts, still lacks confirmation as a bird of the State, or even of New England. It has been taken on Long Island, in New Jersey, and southward to Florida, and also in Greenland, and may well be expected to occur in Massachusetts.

5. Allas crecca. European Teal.-Occurs as a straggler in eastern North America, having been taken at various points from 
Labrador to the Carolinas, but there are as yet no New England records.

6. Olor buccinator. Trumpeter Swan.-In all probability common here two hundred years ago, and may still occur as a straggler. Although there is no recent record of its capture within the State, there is a comparatively recent reference to its supposed occurrence at East Windsor Hill, Conn. (March, 1876), within fifteen miles of the Massachusetts line (Merriam, Rev. Bds. Conn., $1877, \mathrm{r} 20$ ). In several instances where the occurrence of Swans is recorded, there is some doubt as to the species, owing to unsatisfactory identification.

7. Guara alba. White Ibis.-Has been recorded from Connecticut (Grinnell, Am. Nat., IX, I875, 470), South Woodstock, Vt. (Tracy, Orn. and Oöl., X, I885, Iо), and repeatedly from Long Island. The species may occur as an accidental visitor to Massachusetts.

8. Crex crex. Corn Crake.-Of casual occurrence in eastern North America. Was taken at Cranston, R. I., about 1857 (Jencks, Random Notes on Nat. Hist., I, $x 884$, No. 6, 3), and has been taken in several instances on Long Island; also at Troy, N. Y. (Park, Forest and Stream, XXII, Feb. 14, I884, 44), and Salem, New Jersey (Cassin, Proc. Acad. Nat. Sci. Phila., 1855, 265); also in Greenland and the Bermudas.

9. Scolopax rusticola. European Woodcock.-Occasional in eastern North America. There are records of its occurence in Newfoundland, Maine, Long Island, New Jersey, Virginia, and elsewhere in the Atlantic States.

10. Milvulus forficatus. Swallow-tailed Flycatcher.This erratic species has been taken at Wauregan, Conn. (Purdie, Bull. Nutt. Orn. Club, II, 1877, 2 I); St. Johnsburg, Vt. (Jencks, Random Notes on Nat. Hist., I, I884, No. 8, 3); Trenton, N. J. (Abbott, Am. Nat., VI, 1872, 367); in Manitoba, and at York Factory, Hudson's Bay (Seton, Auk, II, I885, 2 I8).

11. Tyramus verticalis. Arkansas KInGBIRD.-This western species has been taken at Elliot (="Plympton"), Maine (Bryant, Proc. Bost. Soc. Nat. Hist., X, 1865, 96; Purdie, Bull. I 886.] 
Nutt. Orn. Club, I, 1876, 73), Riverdale, N. Y. (Bicknell, ibid., IV, I879, 60), and at Moorestown, N. J. (Turnbull, Bds. Eastern Penn., $\mathrm{I} 869,4 \mathrm{I})$, and is as likely to occur in Massachusetts as many other species which have been taken there.

12. Empidonax acadicus. Acadian Flycatcher.-Has been taken at Suffield, Conn. (Merriam, Rev. Bds. Conn., I877,

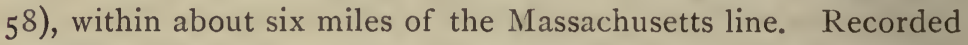
by me in 1864 as occurring at Springfield, but in this instance E. pusillus traillii was mistaken for it, as heretofore stated (Proc. Essex Inst., X, 1878,33 ).

13. Perisoreus canadensis. Canada Jay.-Has been taken at Portland, Me. (Brown, Bull. Nutt. Orn. Club, VII, I882, I 22 ), and at Brandon, Vt. (Knowlton, ibid., VII, r882, 64). Mr. Jenness Richardson informs me that there is a small resident colony of these birds near Rutland, Vt., about fifty miles north of the Massachusetts line, where he has often shot the birds. It doubtless occurs as an occasional winter visitor in Berkshire County. Mr. C. J. Maynard reports seeing "an individual in Newtonville" " in early summer," about 1875 (Bds. East. N. Amer., I 879, r68), but it eluded capture, and there is, so far as known to me, no record of its actual capture in the State. Mr. George N. Lawrence, however, reports the capture of a specimen "on New York Island, near Manhattanville," in midsummer (Ann. N. Y. Lyc. Nat. Hist., VIII, I866, 289), a very unusual season for this bird to be seen so far south.

14. Corvus ossifragus. Fish Crow.-This species is now well known to be a not very rare resident on Long and Staten Islands, and in the lower Hudson Valley (Zerega, Bull. Nutt. Orn. Club, V, 1880, 205; Mearns, Bull. Essex Inst., XII, I880, I 10I 2 ; Purdie, ibid., V, I880, 240; Dutcher, Trans. Linn. Soc. New York, I, I882, I09-III). There is also an old Connecticut record (Linsley, Am. Journ. Sci. and Arts, XLIV, r843, 260). Mr. William Brewster observed a single individual in Cambridge, March I6, I875 (Bull. Nutt. Orn. Club, I, I876, 73), but there is thus far no record of the actual capture of the species within the State.

15. Stelgidopteryx serripennis. Rough-Winged Swallow. - This species has been found breeding at West Point, N. Y. 
(Mearns, Bull. Nutt. Orn. Club, III, 1878, 46), and at Green's Farms, twenty-six miles west of New Haven, Conn., in 1876 and I 877 (Stannis, Bull. Nutt. Orn. Club, IV, 1879, I I9). It was taken by Mr. E. I. Shores at Suffield, Conn., June 6, I874 (ibid., II, 1877, 2 I) - a locality only a few miles south of the Massachusetts line. Mr. John H. Sage also writes me that it was killed at East Hartford, Conn., in June, r 885. Its occasional presence in Massachusetts can, therefore, be scarcely questioned, although there is as yet no record of its actual capture within the State.

16. Dendroica crerulea. Cerulean Warbler.-Has occurred at Suffield, Conn., close to the Massachusetts boundary (Purdie, Bull. Nutt. Orn. Club, II, I877, 22), and at Cumberland Hill, R. I. (Deane, ibid., IV, I879, I85), and is quite likely to be found sooner or later within the State.

17. Geothlypis formosa. Kentucky Warbler.-This species has also been taken at Suffield, Conn. (Merriam, Rev. Bds. Conn., I 877, 22). This is its only New England record, but it has been taken at Sing Sing, N. Y. (Fisher, Am. Nat., IX, I 875, 573), and also in Northern New Jersey.

18. Parus bicolor. Tufted Titmouse.-This species, which occurs sparingly as far north as Long Island and the vicinity of New York City, has several Connecticut records (see Merriam, Rev. Bds. Conn., I877, 9), and has once occurred as near the Massachusetts border as Hartford. There is also an early New Hampshire record (Belknap, Hist. New Hampshire, III, I 792, I 73).

19. Saxicola cenanthe. Wheatear.-Of frequent occurrence in Southern Labrador, where it breeds, and in the Bermudas, and has been taken at Quebec, Canada (Baird, Rev. Am. Bds., I 864, 6i); Indian Island, near Eastport, Maine (Boardman, Bull. Nutt. Orn. Club, V, I880, I I5), and on Long Island, N. Y. (Lazerence, Ann. N. Ÿ. Lyc. Nat. Hist., VIII, 1866, 282). Its capture in Massachusetts is therefore not improbable.

The Crested Grebe (Colymbus cristatus), formerly included among Massachusetts birds, has recently been found to have no status as even a bird of North America.

The Manx Shearwater (Puffinus pufinus), formerly given as more or less frequent off the coast in winter, is now considered I 886.$]$ 
as of doubtful occurrence off the eastern coast of North America, there being no authentic record of its capture on the American side of the Atlantic, south of Greenland.

The two species of Tropic Bird occasionally straggle far beyond their usual range. The Yellow-billed Tropic Bird (Phaëthon flavirostris) is reported to have been taken "in the interior of New York State about the middle of November, 1870" (Maynard, Bds. East. N. Amer. I 879, 474), and the Red-billed Tropic Bird ( $P$. cothereus) is said to be "casual near Newfoundland Banks" (Ridgway, Water Birds N. Amer., II, I884, I89).

The Willow Ptarmigan (Lagopus albus), of which a specimen was taken in Manchester, in May, 1859 (Coues, Proc. Essex Inst., $\mathrm{V}, \mathrm{I} 868,259$ ), is doubtless to be regarded as an escaped cagebird rather than as a species intentionally introduced, or even as an accidental waif.

The Serin Finch (Serinus hortulanus), which has but a single record for the State (Allen, Am. Nat., III, I870, 635), or even for North America, may also doubtless be considered as an escaped cage-bird.

The Evening Grosbeak (Coccothraustes vespertina) has been taken at Toronto (Seton, Auk, II, I885, 334), and at Woodstock (McIlwraith, Proc. Essex Inst., V, I 866, 88) and London, Ontario (Morden and Saunders, Can. Nat. and Sports., II, 1882, I 85. Also in Onondaga County, N. Y. (Coues, Bull. Nutt. Orn. Club, VII, I882, 250), at Elizabethtown, Essex Co., N. Y. (Brewer, Proc. Bost. Soc. Nat. Hist., XVII, I875, 45I), and near New York City (Lawrence, Ann. Lyc. Nat. Hist. New York, VIII, 1866, 289). It may doubtless be looked for as an accidental visitor to Massachusetts.

Linnaeus's Emerald (Thaumatias linnei). A specimen of this species has been recorded as taken in Massachusetts (Allen, Am. Nat., III, 1870,645$)$, but the evidence of its capture in the State has since been found unsatisfactory, while the probabilities are evidently against such an occurrence.

The Empidonax pygmæus (Minot, Land Birds and Game Birds of New England, I 877, 290), described from a bird "caught sight of.... in some shrubbery.... near Boston," is not recognized as having any scientific status.

[July, 


\section{IV.-DOUBTFUL SPECIES.}

1. Acanthis brewsteri. Brewster's Linnet.-The typespecimen of this supposed species, taken at Waltham, by Mr. Brewster (Ridgway, Am. Nat., VI, 1872, 433) remains unique. It is now thought to be possibly a hybrid between Acanthis linaria and Spinus pinus (see Brewester, Bull. Nutt. Orn. Club, VI, r88I, 225).

Helminthophila leucobronchialis. BREWSTER'S W ARBLER.This supposed species was first taken at Newtonville, May I8, 1870 (Brewester, Bull. Nutt. Orn. Club, I, I876, I, pl. i). Numerous specimens have since been taken, particularly in southern Connecticut and in the lower Hudson Valley. (For a full citation of references and analysis of the specimens see Ridgway, Auk, II, r 885, 359-363.) This and $H$. lawencei seem likely to be simply hybrids between $H$. chrysoptera and $H$. pinus (Brewster, Bull. Nutt. Orn. Club, VI, 1881, 218-225; Auk, III, 1886, 411).

The Small-headed Flycatcher (Muscicapa minuta Wilson), which has been twice reported as occurring in Massachusetts, but of which no specimens from anywhere are extant, is considered as too problematical to be entitled to recognition. Whatever it may finally prove to be, the Massachusetts records are too vague to have any value.

\section{V.-INTRODUCED SPECIES.}

1. Tympanuchus americanus. Prairie Hen.-Small numbers of these birds have been repeatedly liberated in various parts of the State, particularly in Barnstable County. Mr. William Brewster, who has given special attention to the matter, says, in a recent letter to me (dated 3 Ist Dec., r885), "I know of several cases where western Grouse [meaning the present species] have been turned out in Massachusetts within the past eight or ten years.... Only last winter a marketman in Boston told me he had some twenty odd sent in by a gunner in Berkshire County.... A few days latter he showed me a letter from his gunner who said that he did not dare kill any more because a sportsman's club which had procured the birds from the West, I886.] 
and which was trying to stock the County with them, had found out that he was killing them and threatened to arrest him.

"I have also heard that within three years many western Grouse have been turned out on the Cape. The people who get and liberate them usually try to keep it a secret, believing that if it is known the market gunners will at once go for them. In short, while it is difficult to get proofs of the fact, I have no doubt that hundreds of Grouse from west of the Mississippi have been quietly introduced in Massachusetts within the last ten years."

Many years since they were introduced from the West to Naushon Island, but appear to have soon become exterminated. As stated above, they have since been liberated in Barnstable County, where several have recently been killed. They doubtless would thrive and increase there if they could be protected from the rapacity of unprincipled gunners.

2. Coturnix cotumix. European Quall-D During the last ten years a considerable number of these birds have been imported and turned out in various parts of the State, and also in neighboring States. So far as now known, the experiment has not been attended with very encouraging success. A few instances of their breeding have been reported, but in the main the birds have been lost sight of, so that the attempt at their naturalization has been practically a failure. (For a history of their introduction, etc., see Forest and Stream, issues of June 28, Aug. 2, Aug. 9, Aug. 23, Sept. 6, Nov. 15, Nov. 29, Dec. 6, and Dec. 27, 1877.)

3. Carduelis elegans. European Goldfinch.-Of late years this species has been repeatedly met with in a wild state in the vicinity of Cambridge and elsewhere near Boston, where doubtless it may be considered as fairly established, as it certainly seems to be in the vicinity of New York, near which city it is known to have been turned out in numbers a few years ago (Adney, Auk, III, r886, 409). It has also been taken at Falmouth, Mass. (Swift, Orn. and Ö̈l., IX, I 884, I2).

4. Passer domesticus. Housf Sparrow.-This introduced pest appears to have now spread to all parts of the State, at least 
to all the larger towns and their immediate neighborhoods, and to have become everywhere ineradicably established, greatly to the regret of all lovers of our native song-birds, to whom this intruder proves so great a nuisance.

\section{GENERAL SUMMARY.}

Fully authenticated as birds of the State, ${ }^{*}$. . . . . . . 340

Extirpated, . . . . . . . . . . . . . . 4

Given as of probable occurrence, . . . . . . . . . . . 19

Considered as fairly entitled to recognition as Massachusetts birds, $\quad 359$

Known as breeding within the State (about), . . . . . . 142

Extremely rare or accidental visitors, . . . . . . . . . . 79

Introduced, . . . . . . . . . . . . . . . . . 4

Species added since 1878 , . . . . . . . . . . . . . . . 23

* Excluding nine varieties of species otherwise represented. 
199 


THIS BOOK IS DUE ON THE LAST DATE STAMPED BELOW

RENEWED BOOKS ARE SUBJECT TO IMMEDIATE RECALL

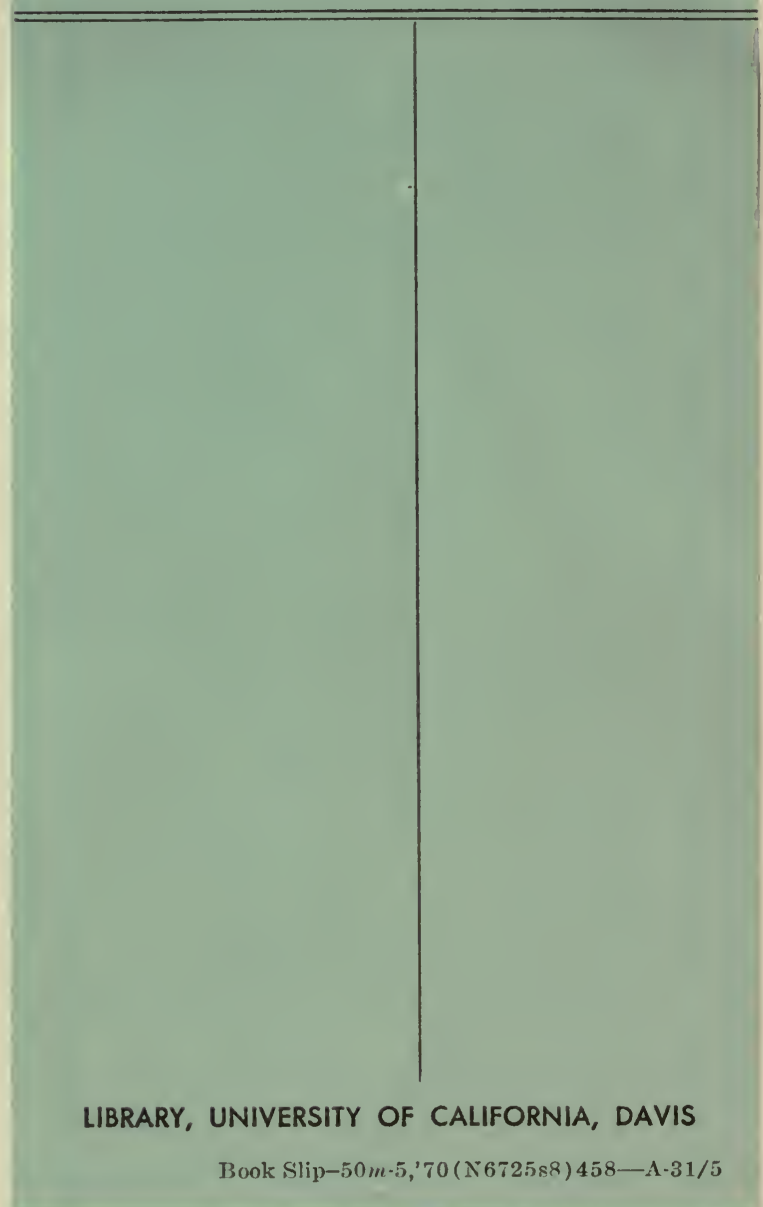


Allen, J.A.

QL684

Birds of

Massachusetts.

M3

A6

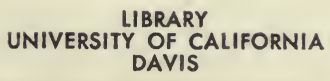




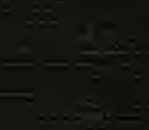

